CIRP Encyclopedia of Production Engineering 
The International Academy for

Production Engineering

Sami Chatti • Luc Laperrière Gunther Reinhart • Tullio Tolio

Editors

\section{CIRP Encyclopedia of Production Engineering}

With 1508 Figures and 110 Tables

算 Springer 
The International Academy for

Production Engineering

Paris, France

Editors

Sami Chatti

National Engineering School

of Monastir (ENIM)

University of Monastir

Monastir, Tunisia

Gunther Reinhart

Institute for Machine Tools and

Industrial Management (iwb)

Technical University of Munich (TUM)

Garching, Germany

Luc Laperrière

Mechanical Engineering

Université du Québec à Trois-Rivières

Trois-Rivières, QC, Canada

Tullio Tolio

ITIA Institute of Industrial Technologies

and Automation

CNR National Research Council

Milan, Italy

ISBN 978-3-662-53119-8

ISBN 978-3-662-53120-4 (eBook)

ISBN 978-3-662-53121-1 (print and electronic bundle)

https://doi.org/10.1007/978-3-662-53120-4

Library of Congress Control Number: 2019932843

(C) CIRP 2014, 2019

This work is subject to copyright. All rights are reserved by the Publisher, whether the whole or part of the material is concerned, specifically the rights of translation, reprinting, reuse of illustrations, recitation, broadcasting, reproduction on microfilms or in any other physical way, and transmission or information storage and retrieval, electronic adaptation, computer software, or by similar or dissimilar methodology now known or hereafter developed.

The use of general descriptive names, registered names, trademarks, service marks, etc. in this publication does not imply, even in the absence of a specific statement, that such names are exempt from the relevant protective laws and regulations and therefore free for general use.

The publisher, the authors, and the editors are safe to assume that the advice and information in this book are believed to be true and accurate at the date of publication. Neither the publisher nor the authors or the editors give a warranty, express or implied, with respect to the material contained herein or for any errors or omissions that may have been made. The publisher remains neutral with regard to jurisdictional claims in published maps and institutional affiliations.

This Springer imprint is published by the registered company Springer-Verlag GmbH, DE, part of Springer Nature.

The registered company address is: Heidelberger Platz 3, 14197 Berlin, Germany 


\section{Preface to Second Edition}

Mankind has a long and successful history of continuously adapting to its changing environment. One of the key elements of this adaptation process is the development of precise skills to design, shape, and repeatedly produce objects with various materials that also evolve: from stone to bronze, from iron to steel, from composite to nano-materials, the quest never ends. As a result of this long evolution process, today, we live in a world of global production: in 2018, we could very well reach a milestone of 75 million cars produced worldwide, while the number of mobile phone users in the world is expected to reach the 5 billion mark by 2019 , requiring a steadily increasing number of produced and sold smartphones (in 2017, there were 1.54 billion smartphone unit sales to end users). Needless to say, the total production of all goods worldwide has simply become intractable.

It is the thesis of this encyclopedia that in a sustainable world, the knowledge about good design practices, materials, and manufacturing technologies used to produce goods should be easily available and shared. Production engineering is a fast-evolving area, and the production map on our little planet, now a global village, has recently undergone very important changes. New technologies are being deployed while manufacturing strategies are constantly changing. Global production networks and supply chains are created, and international cooperation is quickly evolving.

Change is certainly not new, but the speed at which it takes place is. Not surprisingly, the technical vocabulary in this engineering domain also experiences significant expansion. New concepts in the fields of design, optimization, control, and management of processes, machines, and systems continuously emerge, thereby increasing the importance of communication and the need for a rigorous and unified technical terminology.

But one must remember that knowledge, rather than being spontaneous, is an incremental concept. Therefore, right from the beginning, the vision behind this encyclopedia was to bring a good balance between fundamental concepts and new emerging ones. In fact, a good proportion of the terms in this edition is a result of the continuous monitoring and update of established concepts upon which new ones are derived. As such, this encyclopedia is an evolving product where current authors will continuously update their essays based on new technical or economical information, while, at the same time, new authors will continuously be appointed to write about new emerging topics. It is the main objective behind the CIRP Encyclopedia of Production Engineering to provide 
authoritative, exhaustive, fast, and easy access to such precious, fast-evolving information.

The target audience includes researchers, engineers, managers, graduate students, and many others whom day-to-day work gravitates around production engineering technologies in the global market.

CIRP has a long history of standardizing the terminology for technical terms. Since 1962, CIRP issued a number of trilingual dictionaries of production engineering in English, French, and German. Not surprisingly, technical terms are sometimes interpreted differently in their conceptual contexts in the three languages. The dictionaries took account of this by including both definitions of the terms and, in some cases, explanatory illustrations. In this way, CIRP realized one of its fundamental aims, i.e., to enable correct translation of production engineering terms and to contribute to a clear, unambiguous professional communication in the three languages. Throughout the years, some dictionaries were extended to include Danish, Finnish, Norwegian, Swedish, Italian, Spanish, Portuguese, Chinese, and Turkish translations.

In 2007, CIRP and Springer discussed the idea of creating an electronic web version of the dictionaries, referred to as E-dictionaries, where such things as animations, equations, and cross-links to other relevant terms could be included to further enhance the understanding of the definition of each term. As a natural extension, the idea of expanding the definitions into essays was next discussed. At that time, both parties started to refer to the work as an encyclopedia.

In 2009, a pilot project involving 15 essays, 5 in each section of Forming, Cutting, and Assembly, was initiated. Later on that year, a wiki platform was developed and improved by Springer staff according to the feedback and comments provided by CIRP. After the platform was judged to be at an acceptable level of functionality, editors in chief and section editors were appointed, and authors were invited to start using the platform to submit the 15 pilot essays. A successful demo took place at the CIRP General Assembly in Boston in August 2009. From then on, the editors in chief created a list of 256 most relevant technical terms to include in the first edition of what is now called the CIRP Encyclopedia of Production Engineering. The first edition, published in 2014, contained more than 1300 pages, available both in print and online.

The success of the first edition, obviously expressed by, e.g., the high number of downloads motivated the CIRP community and all contributors to publish a second edition with an extended number of terms, from 256 in the first edition to 343 in the second edition. New terms have been added to this edition, exploring new topics of production engineering, and many original terms of the first edition have been revised and updated. Some of the original terms have been even completely rewritten or strongly reworked in order to include the newest developments or new aspects which have meantime arisen.

The 343 entries of the second edition provide more than 1800 pages organized in 11 sections:

- Abrasive Processes

- Assembly

- Cutting

- Design 
- Electrophysical and Chemical Processes

- Forming

- Life Cycle Engineering

- Machines

- Precision Engineering and Metrology

- Production Systems and Organizations

- Surfaces

Certainly, the most fundamental aspect behind the CIRP Encyclopedia of Production Engineering is quality of content. This comprehensive work involves the contribution of about 300 authors from all around the world, mostly CIRP fellows, associates, corporates, or affiliates considered as leading authorities in their field. A thorough review process of each essay was established under the leadership of each of the 12 section editors. We hope the reader finds it as useful referring to it as it was a great experience for us building it.

Professor Sami Chatti

Professor Luc Laperrière Professor Gunther Reinhart

Professor Tullio Tolio

Editors in Chief 


\section{Preface to First Edition}

Mankind has a long and successful history of continuously adapting to its changing environment. One of the key elements of this adaptation process is the development of precise skills to design, shape, and repeatedly produce objects with various materials that also evolve: from stone to bronze, from iron to steel, from composite to nano materials, the quest never ends. As a result of this long evolution process, today we live in a world of global production: in 2012, for the first time, over 60 million cars were produced worldwide, and over 415 million mobile phones were produced only in the first quarter of 2013 ! Needless to say, the total production of all goods worldwide has simply become intractable.

It is the thesis of this encyclopedia that in a sustainable world, the knowledge about good design practices, materials, and manufacturing technologies used to produce goods should be easily available and shared. Production engineering is a fast evolving area, and the production map on our little planet, now a global village, has recently undergone very important changes. New technologies are being deployed while manufacturing strategies are constantly changing. Global production networks and supply chains are created and international co-operation is quickly evolving.

Change is certainly not new, but the speed at which it takes place is. Not surprisingly, the technical vocabulary in this engineering domain also experiences significant expansion. New concepts in the fields of design, optimization, control, and management of processes, machines, and systems continuously emerge, thereby increasing the importance of communication and the need for a rigorous and unified technical terminology.

But one must remember that knowledge, rather than being spontaneous, is an incremental concept. Therefore, right from the beginning, the vision behind this encyclopedia was to bring a good balance between fundamental concepts and new emerging ones. In fact, a good proportion of the terms in this first edition is a result of the continuous monitoring and update of established concepts upon which new ones are derived. As such, this encyclopedia is an evolving product where current authors will continuously update their essays based on new technical or economical information, while at the same time new authors will continuously be appointed to write about new emerging topics. It is the main objective behind the CIRP Encyclopedia of Production Engineering to provide authoritative, exhaustive, fast, and easy access to such precious, fast evolving information. The target audience includes researchers, engineers, managers, graduate students, and many others whom day to day work 
gravitates around production engineering technologies in the global market.

CIRP has a long history of standardizing the terminology for technical terms. Since 1962, CIRP issued a number of trilingual dictionaries of production engineering in English, French, and German. Not surprisingly, technical terms are sometimes interpreted differently in their conceptual contexts in the three languages. The dictionaries took account of this by including both definitions of the terms and, in some cases, explanatory illustrations. In this way, CIRP realized one of its fundamental aims, i.e., to enable correct translation of production engineering terms and to contribute to a clear, unambiguous professional communication in the three languages. Throughout the years, some dictionaries were extended to include Danish, Finnish, Norwegian, Swedish, Italian, Spanish, Portuguese, Chinese, and Turkish translations.

In 2007, CIRP and Springer discussed the idea of creating an electronic web version of the dictionaries, referred to as E-dictionaries, where such things as animations, equations, and cross-links to other relevant terms could be included to further enhance the understanding of the definition of each term. As a natural extension, the idea of expanding the definitions into essays was next discussed. At that time both parties started to refer to the work as an encyclopedia.

In 2009, a pilot project involving 15 essays, 5 in each section of Forming, Cutting, and Assembly, was initiated. Later on that year, a wiki platform was developed and improved by Springer staff according to the feedback and comments provided by CIRP. After the platform was judged to be at an acceptable level of functionality, Editors in Chief and Section Editors were appointed and Authors were invited to start using the platform to submit the 15 pilot essays. A successful demo took place at the CIRP general assembly in Boston in August 2009. From then on, the Editors in Chief created a list of 256 most relevant technical terms to include in the first edition of what is now called the CIRP Encyclopedia of Production Engineering. It contains more than 1300 pages, available both in print and online, organized around 11 chapters:

- Abrasive Processes

- Assembly

- Cutting

- Design

- Electro-Physical and Chemical Processes

- Forming

- Life Cycle Engineering

- Machines

- Precision Engineering and Metrology

- Production Systems and Organizations

- Surfaces

Certainly, the most fundamental aspect behind the CIRP Encyclopedia of Production Engineering is quality of content. This comprehensive work involves the contribution of more than 200 authors from all around the world, mostly CIRP fellows, associates, corporates, or affiliates considered 
as leading authorities in their field. A thorough review process of each essay was established under the leadership of each of the 11 Section Editors. We hope the reader finds it as useful referring to it as it was a great experience for us building it.

Professor Luc Laperrière Professor Gunther Reinhart Editors in Chief 


\section{A word from CIRP}

The International Academy for Production Engineering Research, also known as CIRP $^{1}$, is the world's leading organization for production engineering research and is at the forefront of design, optimization, control, and management of processes, machines, and systems for manufacturing. CIRP promotes research and development among its members from the academia and industry to contribute to the global economic growth and well-being of society. In this context, one of the most fundamental roles of CIRP as a global organization is to ensure as far as possible that the terminology used be standardized and common across all nations of the earth.

To date, the main publications of CIRP have been the CIRP Annals (Manufacturing Technology) and the CIRP Journal of Manufacturing Science and Technology. The CIRP Annals are published under ISI standards each year in two volumes: Vol. I with refereed papers presented during the CIRP General Assembly and Vol. II with refereed keynote papers. The CIRP Journal of Manufacturing Science and Technology is published each year in four volumes. CIRP also publishes the trilingual CIRP Dictionaries of Production Engineering. Besides these main publications, a newsletter is published twice a year, as well as CIRP Internal Documents and Reports from CIRP General Assemblies are available on the CIRP website (www.cirp.net). Finally, the Proceedings of CIRP Conferences are available online on the Procedia CIRP website.

Ten years ago, the CIRP Terminology Committee decided to follow a totally new pathway in answer to the new age of advanced communications technology, to the advancing internet age, and to the cloud capabilities. As an outcome of the work undertaken, an online platform was launched in 2012 for the provision of authoritative, exhaustive, fast, and easy access to terms, definitions, and a whole set of information in the field of production/ manufacturing engineering. The CIRP Encyclopedia of Production Engineering was launched and represents the natural extension of the current $C I R P$ Dictionaries of Production Engineering. This encyclopedia consists of a list of entries that describe each term with definitions, theory, and applications. It is available both in print and on a website (http://link.springer.com). The definitions are based on the current content of the CIRP Dictionaries of Production Engineering, with new terms being added as required.

\footnotetext{
${ }^{1}$ The acronym CIRP comes from the French appellation of the academy, namely, Collège International pour la Recherche en Productique, headquartered in Paris.
} 
This is a new and exciting publication, and I believe that it represents an extremely important contribution to the unification of the terminology used in the world. We need easy availability of terms using modern communications devices. With the CIRP Encyclopedia of Production Engineering as an important step forward, a significant step building on the past and capitalizing on the capabilities of current and future communications technology has been achieved.

Professor Don Lucca, CIRP President (2017-2018) 


\section{Acknowledgments}

This encyclopedia was initiated from the experience and long-term vision of Professor Hans Kurt Toenshoff. We sincerely acknowledge his dedication and numerous advices. Thanks to the former CIRP President, Gerry Byrne, who believed in the project right from the start and who never missed a chance to promote it. We also wish to express our gratitude to Thomas Lehnert from Springer, an initial investigator in this project, and to Dr. Jan-Philip Schmidt, Editor Interdisciplinary Applied Sciences at Springer. We finally extend our thanks to other Springer staff, in particular to Barbara Wolf and Audrey Ohlig, for their constant and rigorous involvement and communication with CIRP authors and editors. 


\section{List of Topics}

\section{Abrasive Processes [STC-G]}

\section{Section Editor: Konrad Wegener}

Abrasive Material

Bonding Materials for Abrasive Tools

Centerless Grinding

Chip Formation (Abrasive Process)

Creep Feed Grinding

Diffusion Soldering

Dressing

Electrochemical Dressing

Electrochemical Grinding

Electrolytic In-Process Dressing

Finishing

Gear Grinding

Grind-Hardening

Grinding

Grinding Burn

Grinding Fluids

Grinding Machines

Grinding Monitoring

Grinding Parameters

Grinding Tool Structuring

Grinding Wheel

High Performance Grinding

High-Performance Dry Grinding

Honing

Lapping

Nozzle Design

Ploughing

Polishing

Residual Stress (Abrasive Processes)

Silver Sintering

Superabrasives
Superfinishing

Ultraprecision Grinding

Water-Jet Cutting

\section{Assembly [STC-A]}

\section{Section Editor: Jörg Krüger}

Assembly

Assembly Automation

Assembly Line

Assembly Representation

Automatic X-ray Inspection (AXI)

Bonding

Brazing and Soldering

Durability Test

Electric Test

Ergonomic Assessment

Feeding

Grasping

Handling

Human Centered Automation

Human-Machine Collaboration

Inspection (Assembly)

Laser Welding

Maintenance

Manual Assembly

Material Flow

Optical Inspection

Robot

Sensor (Assembly)

SMD Component Placement

Solder Paste Printing

Wave Soldering 
Welding

Wire Bonding

\section{Cutting [STC-C]}

\section{Section Editor: Garrett O’Donnell}

Adiabatic Shearing in Metal Machining

Broaching

Burr

Cemented Carbides

Ceramic Cutting Tools

Cermets

Chatter Prediction

Chip-Forms, Chip Breakability, and Chip Control

Coated Tools

Composite Materials

Cutting Edge Geometry

Cutting Edge Influence on Machining Titanium Alloy

Cutting Fluid

Cutting Force Modeling

Cutting of Inconel and Nickel Base Materials

Cutting Temperature

Cutting, Fundamentals

Deep Hole Drilling with Small Diameters

Diamond Machining

Drill Milling

Drilling

Fine Finishing of Holes

Five-Axis Tool Path Generation

Gear Cutting

Geometric Modeling of Machining

Groove Milling

Hard Material Cutting

Heat Partitioning in Dry Milling

High Speed Cutting

Hybrid Cutting

Machinability

Machinability of Aluminum and Magnesium Alloys

Machinability of Carbon Steel

Machinability of Carbon-Fiber-Reinforced and GLARE Materials

Machinability of High-Alloyed Steel and

Stainless Steel

Machining of Spheroidal Ductile Iron
Micromachining

Milling of Titanium

Modeling in Cutting

Modeling of Face Milling

Molecular Dynamics for Cutting Processes

Monitoring

Process Chain Design

Process Optimization via Feedrate Scheduling in Milling

Residual Stresses in Machining Operations

Self-Propelled Rotary Tool

Superhard Tools

Surface Integrity

Sustainability of Machining

Tool Holder

Turning with Rotary Tools

Twist Drill Geometry Optimization

Ultra Small Micro End Mills

Ultraprecision Machining

Wear Mechanisms

\section{Design [STC-DN]}

Section Editor: Eric Lutters

Augmented Reality

Axiomatic Design

Biomimetic Design

Computer-Aided Design

Conceptual Design

Decision-Making

Design Methodology

Engineering Design

Function Modeling

Information Management

Knowledge Management

Lean Design

Modular Design

Product Architecture

Product Development

Prototyping

Requirement Specification

Reverse Engineering

Roundness

Smart Products

Straightness

Synthesis 
Tolerancing

Tolerancing (Kinematic Approach to)

TRIZ

Virtual Reality

“What-If” Design

\section{Electrophysical and Chemical Processes} [STC-E]

\section{Section Editor: Ludger Overmeyer}

Additive Manufacturing Technologies

Chemical Vapor Deposition (CVD)

Cold Spray

Electric Discharge Machining

Electroforming

Electron Beam Machining

Etching

Eutectic Bonding

Induction Heating

Ion Beam Machining

Laser Ablation

Laser Beam Machining

Microwave Radiation

Physical Vapor Deposition (PVD)

Pulse

Rapid Tooling

Self-Vibratory Drilling

Specific Energy

Sputtering

\section{Forming [STC-F]}

Section Editor: Bernd-Arno Behrens

Anisotropy

Bar Extrusion

Bending (Sheets)

Bending (Tubes, Profiles)

Billet Shearing

Cold Forging

Cross Wedge Rolling

Deep Drawing

Deformation (Dislocations)

Drawing (Wire, Tube)

Embossing

Finite Element Analysis
Flow Forming

Flow Stress, Flow Curve

Forge Rolling

Formability (Damage)

Forming Presses (Hydraulic, Mechanical, Servo)

Forming Tools (Die, Punch, Blank Holder)

Friction

Hot Forging

Hot Stamping

Hydroforming (Sheets and Tubes)

Incremental Forming

Joining by Upset Bulging

Mechanical Joining

Metal Spinning

Residual Stress (Forming)

Roll Levelling

Roll-Forming

Rolling

Shear Cutting

Shear Forming

Sheet-Bulk Metal Forming

Springback

Stress, Strain

Stretching

Tailored Blanks

Thixoforming

Yield Criteria

\section{Life Cycle Engineering [STC-LCE]}

\section{Section Editor: Wim Dewulf}

Cleaner Production

Disassembly

Eco-efficiency

Energy Efficiency

Environmental Impact

Environmental Impact Assessment

EOL Treatment

Life Cycle Assessment

Life Cycle Assessment: Goal and Scope

Definition

Life Cycle Cost

Life Cycle Engineering

Life Cycle Impact Assessment

Product Life Cycle Management

Recycling 
Remanufacturing

Resource Efficiency

Reuse

Sustainability

Sustainable Manufacturing

\section{Machines [STC-M]}

\section{Section Editor: Hans-Christian Möhring}

Actuator

Adaptive Control

Bearing

Chatter

Computer Numerical Control

Control

Damping

Dynamics

Finite Element Method

Hydrostatic Bearing

Machine Tool

Magnetic Bearing

Mechanism

Mechatronics

Open Architecture

Sensor (Machines)

Servo System

Spindle

Stability

Structural Analysis

Thermal Error

Ultraprecision

Vibration

\section{Precision Engineering and Metrology}

[STC-P]

\section{Section Editors: M. Alkan Donmez and Robert Schmitt}

Abbe Error/Offset

Accuracy

Adaptive Optics

Atomic Force Microscopy

Calibration

Computed Tomography

Coordinate Measuring Machine
Error

Flatness

Form Error

Geometrical Product Specification

In-Process Inspection

Inspection (Precision Engineering and Metrology)

Interferometry

Measurement System Analysis

Measurement Uncertainty

Metrology

Positioning

Precision

Precision Positioning

Quality

Quality Assurance

Resolution

Reversal

Scanning Electron Microscope

Scanning Tunneling Microscope

Topography

Traceability

\section{Production Systems and Organizations [STC-O]}

\section{Section Editor: Günther Schuh}

Agent Theory

Algorithm

Artificial Intelligence

Assembly Systems

Autonomous Production Control

Capacity Planning

Changeable Manufacturing

Cladistics for Products and Manufacturing

Complexity in Manufacturing

Computer-Aided Manufacturing

Computer-Aided Process Planning

Computer-Integrated Manufacturing

Cooperative Engineering

Cost

Cyber-Physical Systems

Distributed Manufacturing

Emergent Synthesis

Energy-Efficient Manufacturing

ERP Enterprise Resource Planning 
Facility Planning

Factory

Flexible Manufacturing System

Fuzzy Logic

Holonic Manufacturing Systems

Industrial Product-Service System

Coevolution of Manufacturing Systems

Knowledge-Based System

Lean Production

Learning Factory

Learning Organization

Logistic Curves

Logistics

Management of Production Enterprises

Manufacturing

Manufacturing System

Mass Customization

Neural Network

Operations Management

Optimization in Manufacturing

Optimization in Manufacturing Systems,

Fundamentals

Planning

Process

Production

Production Networks

Production Planning

Productivity

Reconfigurable Manufacturing System

Scheduling
Simulation of Manufacturing Systems

Statistical Process Control

Supply Chain Management

System

Virtual Reality in Manufacturing

\section{Surfaces}

Section Editor: Han Haitjema

Corrosion

Crack Initiation

Ellipsometry

Freeform

Functional Correlation

Microstructure

Molecular Dynamics

Nanoindentation

Nanotechnology

Peening

Reflectivity

Roughness

Scatterometry

Stratified Surface

Surface Parameter

Surface Texture

Surface Texture Filtering

Surface Texture Metrological Characteristics 


\section{About the Editors}

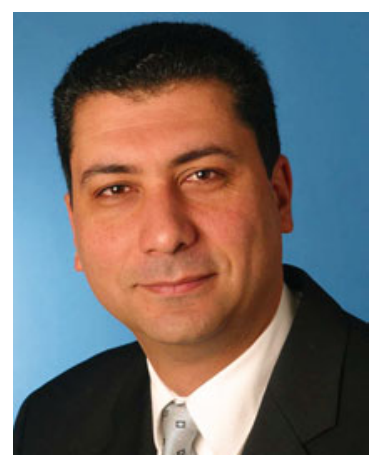

Sami Chatti is a professor in the Mechanical Engineering Department of the National Engineering School of Monastir (ENIM), University of Monastir, Tunisia. He is the main coordinator of the flexible modular master program in technology (MasTech), developed within a European project under his leadership for six universities in the three countries Tunisia, Algeria, and Morocco.

Professor Chatti obtained his degree in mechanical engineering with main focus on manufacturing engineering at the TU Dortmund University, Germany, as well as his doctoral degree in forming technology with a dissertation about optimization of the manufacturing accuracy in profile bending. With a habilitation thesis entitled "Production of Profiles for Lightweight Structures," he obtained his postdoctoral degree at the University of Franche-Comté, Besançon, France, in cooperation with TU Dortmund University.

He worked until December 2016 as senior researcher, chief engineer education (director of studies), and member of the direction group of the Institute of Forming Technology and Lightweight Construction (IUL) of TU Dortmund University.

Professor Chatti is, since 2007, guest professor at the Department of Production Engineering, Royal Institute of Technology (KTH), Stockholm, Sweden, and was the main coordinator of the mini symposium "Light Weight Design and Energy Efficiency in Metal Forming" of the European Scientific Association for Material Forming (ESAFORM) conferences from 2011 to 2015.

He is vice-chairman of the CIRP Terminology Committee and member of the international group who revised the "CIRP Dictionary of Production 
Engineering," volume "forming" in the languages German, English, and French.

Sami Chatti is married and has three children. He is member of several associations like CIRP and ATM (Association Tunisienne de Mécanique). He has filed 2 patents and has published 9 book chapters and over 100 papers in scientific journals, magazines, and international refereed conferences.

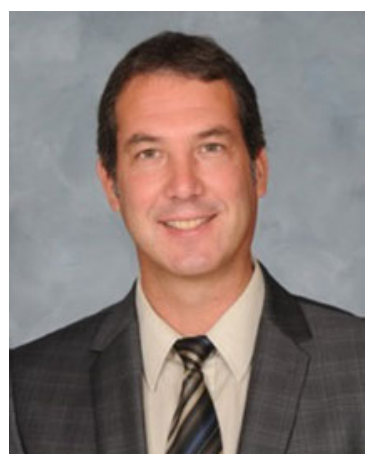

Luc Laperrière is a full-time professor in the Mechanical Engineering Department of Université du Québec à Trois-Rivières since 1991. He received both his master's and Ph.D. degrees from McMaster University, Canada, in 1990 and 1992, respectively. He was also appointed chair of his department from 2010 to 2013 and from 2016 to 2019.

During a sabbatical in 1999, he developed new and original artificial intelligence software. This was done in collaboration with a commercial software distributor. The developed modules are still part of the basic version of this software distributed worldwide.

In 2005, he was leading a multidisciplinary engineering team responsible for the design and implementation of the distributed control system (DCS) of a fully operational pulp and paper mill with a complete paper machine in a new $11,000 \mathrm{~m}^{2}$ building on campus, representing a total investment of $80 \mathrm{M} \$ \mathrm{Cdn}$, $10 \%$ of which came directly from industry. This DCS manages over $3000 \mathrm{I} / \mathrm{Os}$ and 500 control loops. Its flexibility is still unique worldwide.

In 2010, he became the founding director of a new research laboratory on natural fiber composites (NFCs). With his students, he helped develop a fullscale pilot plant dedicated to the manufacturing of a vast variety of NFCs.

He has filed 2 patents, has published over 100 papers in leading scientific journals and international refereed conferences, and has supervised over 40 master's and Ph.D. students. 


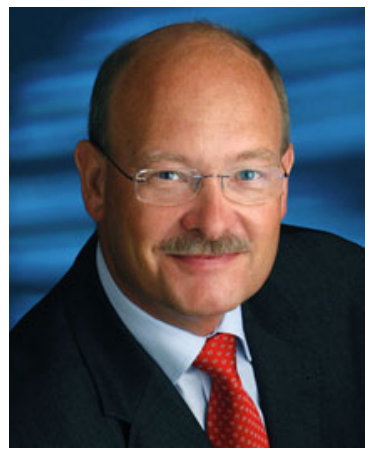

Gunther Reinhart is full professor for Industrial Management and Assembly Technology and director of the iwb (Institute for Machine Tools and Industrial Management) at Technische Universität München. After studying mechanical engineering with the emphasis on design and development, he was research assistant at iwb from 1982 to 1988 with Prof. Dr. Joachim Milberg. During the last 2 years, he was in charge of the Assembly Automation Department. After receiving his Ph.D. from Technische Universität München, Prof. Reinhart started his industrial career with the BMW Group, initially as head of the Handling and Welding Engineering Department and subsequently as director of the body paint shop. In 1993, he returned to university to become professor and director of the iwb.

From March 2002 to February 2007, Prof. Reinhart took a sabbatical from the university to become a member of the Executive Board of IWKA Corporation, a large German supplier of engineering, robotics, and plant equipment with 13,000 employees worldwide. He was in charge of Technology and Market (CTO) focused on the discovery of new global market opportunities, the establishment of an internal auditing system, and the development of the IWKA packaging technology group.

In 2007, Prof. Reinhart returned to university and has served with Prof. Michael F. Zäh as co-director of the Institute for Machine Tools and Industrial Management (iwb) with more than 100 employees and 2 locations: Garching near Munich and Augsburg. He is also the chairman of the Bavarian Cluster for Mechatronics and Automation e.V. and, since January 1, 2009, head of the Fraunhofer IWU Research Department for Resource-Efficient Converting Machines (RMV).

Gunther Reinhart is member of multiple scientific societies and associations, e.g., acatech, WGMHI, CIRP, WGP, and WiGeP. He has approximately 300 publications in leading trade journals to his credit and is author or editor of 2 books and 2 series. He has also supervised the research projects and the doctoral theses of some 100 research associates. 


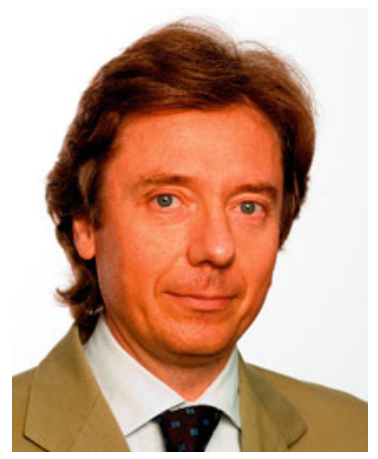

Tullio Tolio is full professor of "Manufacturing and Production Systems" at Politecnico di Milano (TU-Milan http://www.polimi.it/en/home/). He is the director of ITIA-CNR (Institute of Industrial Technologies and Automation of the National Research Council of Italy http://www.itia.cnr.it/en/).

He has carried out research activities at the Laboratory for Manufacturing and Productivity (LMP) of the Massachusetts Institute of Technology (MIT). He is director of the Flagship project "Factories of the Future Italy," and in his position of director of ITIA-CNR, he has defined the strategy of the institute on more than 40 EU projects.

He has published more than 150 papers in international journals and international conferences. He has been associate editor of the SME Journal of Manufacturing Systems (2008-2014); he is currently member of the Editorial Board of the CIRP Annals, associate editor of the international Journal of Manufacturing Science and Technology, and editor in chief of the CIRP Encyclopedia. He is member of the Scientific Committee of five annual or biannual international conferences, and he has been the organizer of four editions of international conferences.

$\mathrm{He}$ is fellow of the CIRP (the International Academy for Production Engineering), member of the High Level Group (HLG) on Key Enabling Technologies (KETs) of the EU, member of the HLG Manufuture (EU platform), and member of the Partnership Board of the UE-Factories of the Future (FoF).

He has been head of the Ph.D. program in "Manufacturing and Production Systems" at Politecnico di Milano (TU Milan) (2000-2003), member of the Evaluation Board of Politecnico di Milano (TU Milan) (2002-2005), delegate of the Rector of Politecnico di Milano on "Quality Assurance in Education" (2005-2008), head of the Division "Tecnologie Meccaniche e Produzione (Manufacturing)" of the Department of Mechanical Engineering of Politecnico di Milano (TU Milan) (2001-2003 and 2005-2008), president of the national Cluster Intelligent Factories (2012-2015), and member of the Directory Board of AITEM (Italian Association for Manufacturing) (2009-2017).

Currently, he is director of ITIA-CNR (Institute of Industrial Technologies and Automation of the National Research Council of Italy) (since 2008), president of AITEM (Italian Association for Manufacturing), president of the Scientific-Technical Committee of the Italian Cluster Intelligent Factories (since 2015), and member of the Directory Board of AFIL (Cluster Intelligent Factories Lombardy). 


\section{Section Editors to Second Edition}

\section{Abrasive Processes}

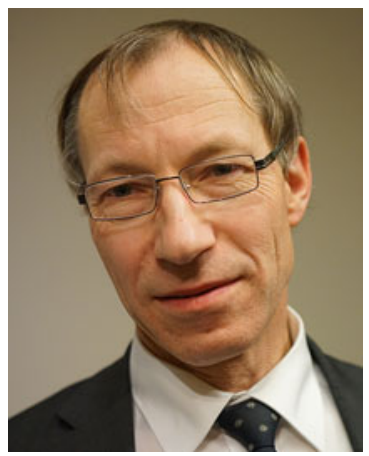

Konrad Wegener Institut für Werkzeugmaschinen und Fertigung (IWF), ETH Zürich, Zürich, Switzerland

\section{Assembly}

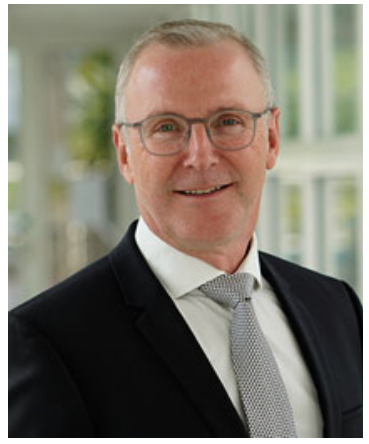

Jörg Krüger Industrial Automation Technology, Institute for Machine Tools and Factory Management (IWF), Berlin, Germany 


\section{Cutting}

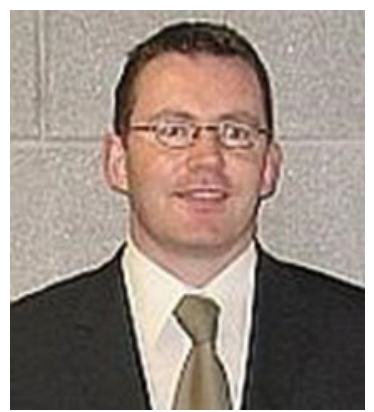

Garrett O'Donnell Mechanical and Manufacturing Engineering, Trinity College Dublin, Dublin, Ireland

\section{Design}

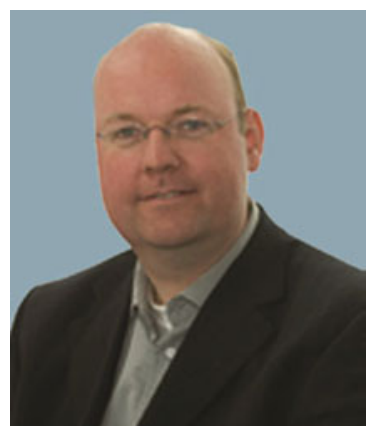

Eric Lutters Faculty of Engineering Technology, Department of Design, Production and Management, University of Twente, Enschede, The Netherlands

\section{Electrophysical and Chemical Processes}

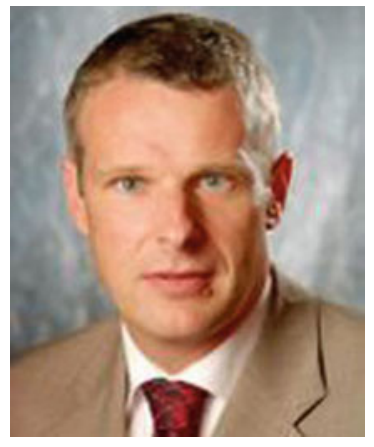

Ludger Overmeyer Institute of Transport and Automation Technology, Leibniz University Hannover, Garbsen, Germany 


\section{Forming}

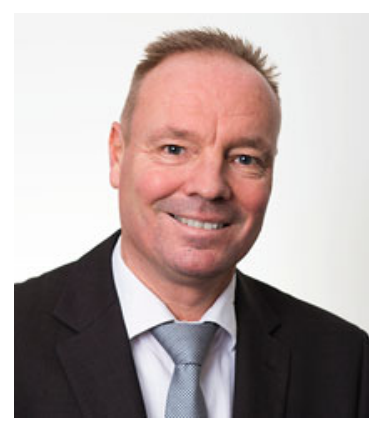

Bernd-Arno Behrens Institute of Forming Technology and Machines, Leibniz Universität Hannover, Garbsen, Germany

\section{Life Cycle Engineering}

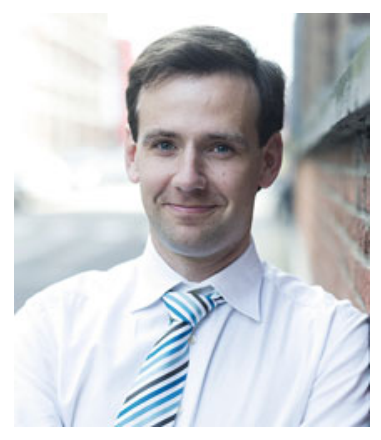

Wim Dewulf KU Leuven, Department of Mechanical Engineering, Leuven, Belgium

\section{Machines}

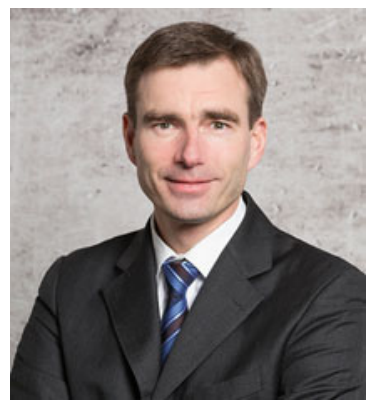

Hans-Christian Möhring Institute for Machine Tools, University of Stuttgart, Stuttgart, Germany 
Precision Engineering and Metrology (A-L)

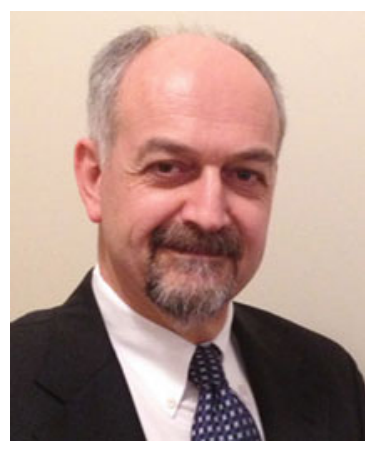

M. Alkan Donmez National Institute of Standards and Technology (NIST), Gaithersburg, MD, USA

\section{Precision Engineering and Metrology $(\mathrm{M}-\mathrm{Z})$}

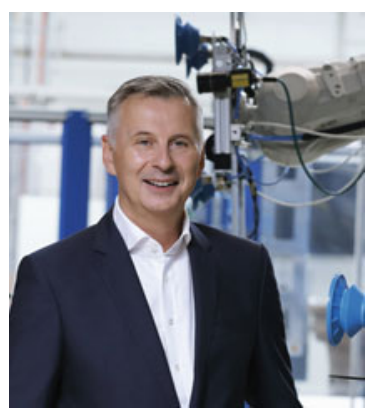

Robert Schmitt Laboratory for Machine Tools and Production Engineering (WZL), RWTH Aachen University, Aachen, Germany

\section{Production Systems and Organizations}

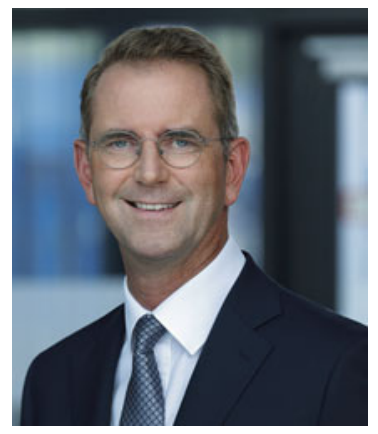

Günther Schuh Forschungsinstitut für Rationalisierung (FIR) e. V, RWTH Aachen, Aachen, Germany 


\section{Surfaces}

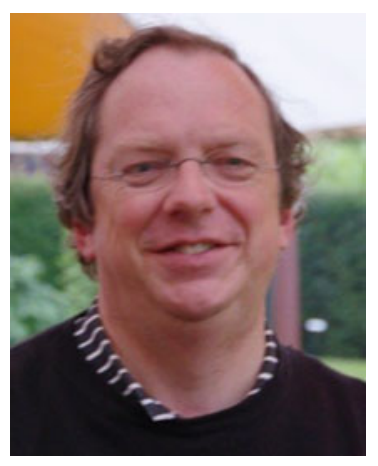

Han Haitjema Mitutoyo RCE, Best, The Netherlands

KU Leuven, Department of Mechanical Engineering, Leuven, Belgium 


\section{Section Editors to First Edition}

\section{Abrasive Processes}

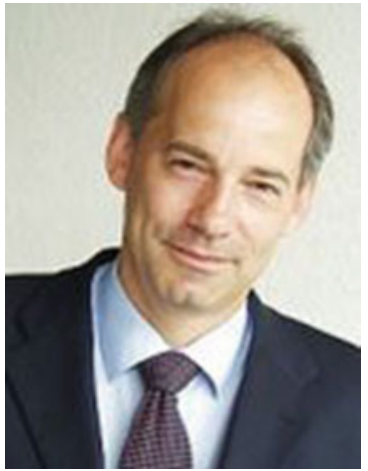

Jan C. Aurich University of Kaiserslautern, Director of Centre of Production Technology FBK, Kaiserslautern, Switzerland

\section{Surfaces}

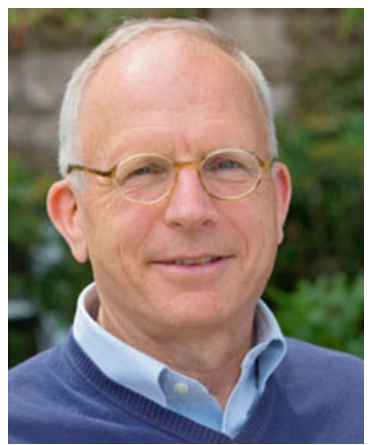

Christopher A. Brown Worcester Polytechnic institute, Worcester, MA, USA 


\section{Machines}

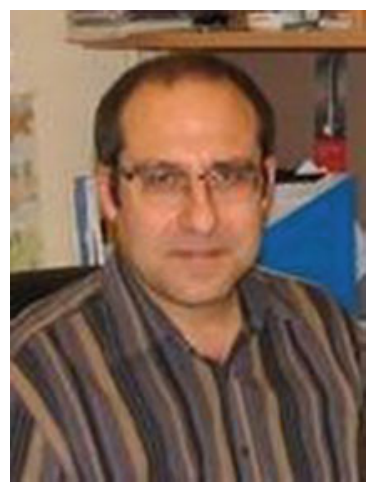

Erhan Budak Faculty of Engineering and Natural Sciences, Sabanci University, Manufacturing Research Lab., Orhanli, Tuzla,, Istanbul, Turkey

\section{Precision Engineering and Metrology (A-L)}

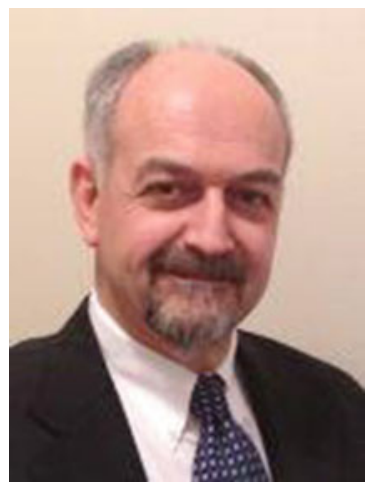

M. Alkan Donmez National Institute of Standards and Technology (NIST), Gaithersburg, MD, USA

\section{Assembly}

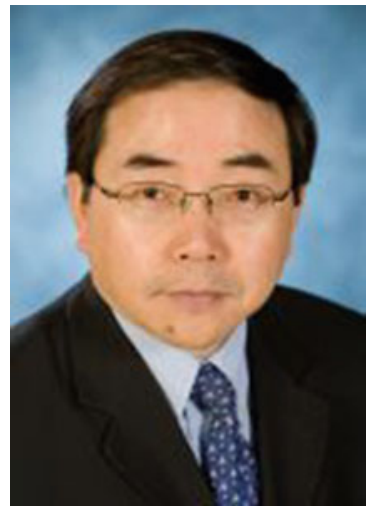

S. Jack Hu College of Engineering Industrial and Operations Engineering, University of Michigan, Ann Arbor, MI, USA 


\section{Life Cycle Engineering}

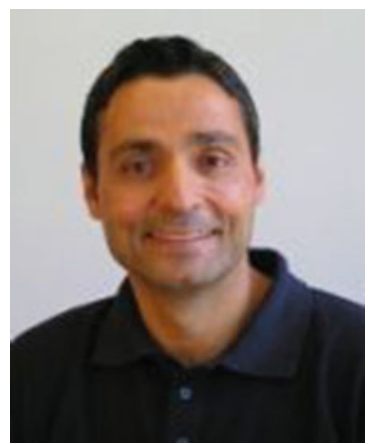

Sami Kara School of Mechanical and Manufacturing Engineering, The University of New South Wales, Sydney, NSW, Australia

\section{Design}

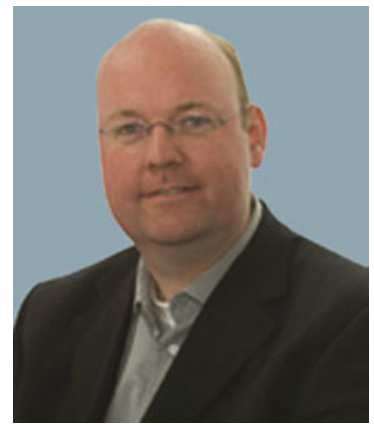

Eric Lutters University of Twente, Faculty of Engineering Technology Laboratory of Design, Production and Management, AE Enschede, The Netherlands

\section{Electro-Physical and Chemical Processes}

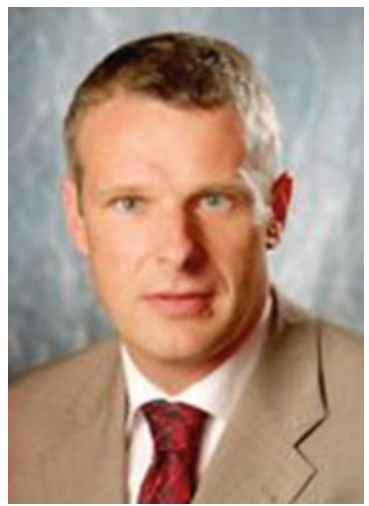

Ludger Overmeyer Institute of Transport and Automation Technology, Garbsen, Germany 


\section{Precision Engineering and Metrology (M-Z)}

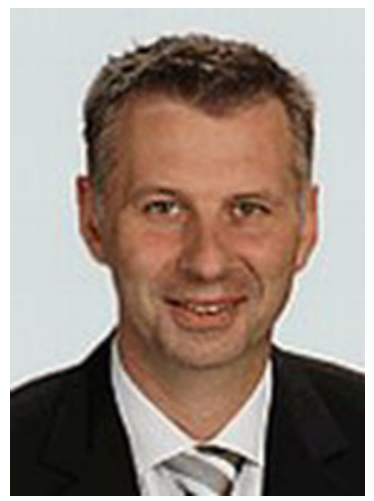

Robert Schmitt RWTH Aachen, Chair for Production Measurement and Quality Management, Lab for Machine Tools, Aachen, Germany

\section{Production Systems and Organizations}

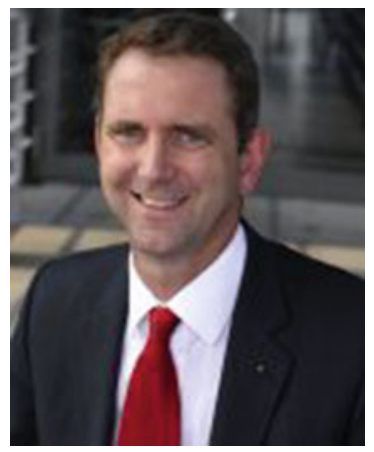

Günther Schuh WZL of the RWTH Aachen University, Aachen, Germany

\section{Forming}

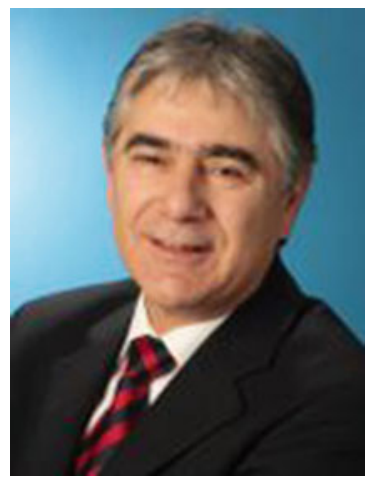

A. Erman Tekkaya Institute of Forming Technology and Lightweight Construction, University of Dortmund, Dortmund, Germany 


\section{Cutting}

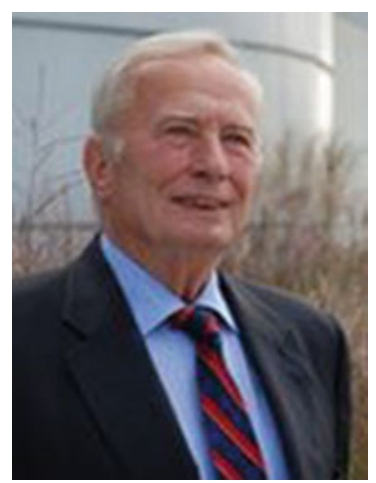

Hans Kurt Toenshoff Institute of Production Engineering and Machine Tools, Leibniz University Hannover, Garbsen, Germany 


\section{Contributors}

Eberhard Abele Institut für Produktionsmanagement, Technologie und Werkzeugmaschinen, Technische Universität Darmstadt, Darmstadt, Germany

Michael Abramovici Lehrstuhl für Maschinenbauinformatik, RuhrUniversität Bochum, Bochum, Germany

Kosmas Alexopoulos Laboratory for Manufacturing Systems and Automation (LMS), Department of Mechanical Engineering and Aeronautics, University of Patras, Patras, Greece

Tarek AlGeddawy Department of Mechanical and Industrial Engineering, University of Minnesota, Duluth, MN, USA

David Allen (Formerly) Materials Department, Cranfield University, Bedfordshire, UK

Julian Allwood Department of Engineering, University of Cambridge, Cambridge, UK

Amer Almohallami Institute of Forming Technology and Machines, Leibniz Universität Hannover, Garbsen, Germany

Yusuf Altintas Faculty of Applied Science, Department Mechanical Engineering/MAL- Manufacturing Automation Laboratory, University of British Columbia, Vancouver, BC, Canada

Raouf Ben Amor Kennametal Shared Services GmbH, Fürth, Germany

Tojiro Aoyama System Design Engineering, Keio University, Minato-ku, Tokyo, Japan

P. J. Arrazola Faculty of Engineering, Manufacturing Department, Mondragon Unibertsitatea, Arrasate-Mondragon, Gipuzkoa, Spain

Jan C. Aurich FBK - Institute for Manufacturing Technology and Production Systems, University of Kaiserslautern, Kaiserslautern, Germany

Markus Bambach Chair for Mechanical Design and Manufacturing, BTU Cottbus-Senftenberg, Cottbus, Germany

Dorel Banabic CERTETA-Research Center in Sheet Metal Forming, Technical University of Cluj Napoca, Romania, Cluj Napoca, Romania 
Dev Banerjee Kennametal Inc., Latrobe, PA, USA

John Barry Advanced Materials, Element Six Ltd, Shannon, Clare, Ireland

Christoph Baumgart Institut für Werkzeugmaschinen und Fertigung (IWF), ETH Zürich, Zürich, Switzerland

Marcin Bauza Carl Zeiss Industrial Metrology, Maple Grove, MN, USA

Bernd-Arno Behrens Institute of Forming Technology and Machines, Leibniz Universität Hannover, Garbsen, Germany

Alain Bernard IRCCyN UMR CNRS 6597 - System Engineering - Products, Performances, Perceptions, Ecole Centrale de Nantes, Nantes, France

Dirk Biermann Institut für Spanende Fertigung, Technische Universität Dortmund, Dortmund, Germany

François Blateyron Digital Surf, Besançon, France

Volker Boess Institut für Fertigungstechnik und Werkzeugmaschinen, Leibniz Universität Hannover, Garbsen, Germany

Martin Bohley FBK - Institute for Manufacturing Technology and Production Systems, University of Kaiserslautern, Kaiserslautern, Germany

Wolfgang Boos Laboratory for Machine Tools and Production Engineering, Rheinisch-Westfälischen Technischen Hochschule Aachen, Aachen, Germany

Emmanouil Bouzakis Department of Engineering, German University of Technology in Oman (GUtech), Muscat, Oman

Konstantinos-Dionysios Bouzakis Laboratory for Machine Tools and Manufacturing Engineering and Fraunhofer Project Center Coatings in Manufacturing (PCCM)/Mechanical Engineering Department, School of Mechanical Engineering, Aristoteles University of Thessaloniki, Thessaloniki, Greece

Alan Bramley Mechanical Engineering, University of Bath, Bath, UK

Günter Bräuer Fraunhofer-Institute for Surface Engineering and Thin Films IST, Braunschweig, Germany

Christian Brecher Werkzeugmaschinenlabor WZL der RWTH Aachen, Aachen, Germany

Bernd Breidenstein Institut für Fertigungstechnik und Werkzeugmaschinen, An der Universität 2, Garbsen, Germany

Ekkard Brinksmeier University of Bremen, Leibniz-IWT, Bremen, Germany

Alexander Brosius Institute of Manufacturing Science and Engineering, TU Dresden, Dresden, Germany 
Christopher A. Brown Department of Mechanical Engineering, Worcester Polytechnic Institute, Worcester, MA, USA

Christoph Brummer Fraunhofer Institute for Production Technology IPT, Aachen, Germany

Erhan Budak Manufacturing Research Laboratory, Faculty of Engineering and Natural Sciences, Sabanci University, Istanbul, Turkey

Peter Butala Department of Control and Manufacturing Systems, University of Ljubljana, Ljubljana, Slovenia

Alessandra Caggiano Department of Industrial Engineering, Fraunhofer Joint Laboratory of Excellence on Advanced Production Technology (Fh-J_LEAPT Naples), University of Naples Federico II, Naples, Italy

Matteo Calaon Department of Mechanical Engineering, Technical University of Denmark, Kongens Lyngby, Denmark

Jian Cao Department of Mechanical Engineering, McCormick School of Engineering and Applied Science, Northwestern University, Evanston, IL, USA

Simone Carmignato Department of Management and Engineering, University of Padua, Vicenza, Italy

Homero Castaneda National Corrosion and Materials Reliability Laboratory, Texas A\&M University, College Station, TX, USA

Dirk Cattrysse Department of Mechanical Engineering, Centre for Industrial Management, KU Leuven, Leuven, Belgium

Elisabetta Ceretti Department of Mechanical and Industrial Engineering, University of Brescia, Brescia, Italy

Sami Chatti National Engineering School of Monastir (ENIM), University of Monastir, Monastir, Tunisia

Tom Childs Faculty of Engineering, University of Leeds, Leeds, UK

Francois Christophe Department of Computer Science, University of Helsinki, Helsinki, Finland

George Chryssolouris Laboratory for Manufacturing Systems and Automation (LMS), Department of Mechanical Engineering and Aeronautics, University of Patras, Patras, Greece

Eric Coatanéa Department of Mechanical Engineering and Industrial Systems, Tampere University of Technology, Tampere, Finland

Marcello Colledani Department of Mechanical Engineering, Politecnico di Milano, Milan, Italy

Kurt Coppens KU Leuven - Campus De Nayer, Sint-Katelijne-Waver, Belgium 
Doriana Marilena D'Addona Department of Chemical, Materials and Industrial Production Engineering, University of Naples Federico II, Naples, Italy

Mohammad Dalaee inspire AG, Zürich, Switzerland

Roy Damgrave Department of Design, Production and Management, University of Twente, Enschede, The Netherlands

Winnie Dankers Department of Design, Production and Management, University of Twente, Enschede, The Netherlands

Jean-Yves Dantan Arts et Métiers, LCFC, ENSAM, Metz, France

Jos de Lange Faculty of Engineering Technology, Department of Design, Production and Management, University of Twente, Enschede, The Netherlands

Ahmed M. Deif Orfalea College of Business, California Polytechnic State University (CAL POLY), San Luis Obispo, CA, USA

Franz Dietrich Institute of Machine Tools and Production Technology, TU Braunschweig, Braunschweig, Germany

Gino Dini Department of Civil and Industrial Engineering, University of Pisa, Pisa, Italy

Claus Dold Inspire AG, Swiss Federal Institute of Technology (ETH), Zürich, Switzerland

David Dornfeld University of California, Berkley, CA, USA

Welf Guntram Drossel Fraunhofer Institute for Machine Tools and Forming Technology IWU, Chemnitz, Germany

Joost R. Duflou Department of Mechanical Engineering, Centre for Industrial Management, KU Leuven, Leuven, Belgium

Jan Friedrich Düsing Laser Zentrum Hannover e.V., Hannover, Germany

Christian Effgen Günter Effgen GmbH, Herrstein, Germany

Konstantinos Efthymiou Laboratory for Manufacturing Systems and Automation (LMS), Department of Mechanical Engineering and Aeronautics, University of Patras, Patras, Greece

Hoda A. EIMaraghy Intelligent Manufacturing Systems Center, University of Windsor, Windsor, ON, Canada

Canada Research Chair in Manufacturing Systems, Intelligent Manufacturing Systems Centre, University of Windsor, Windsor, ON, Canada

Waguih H. EIMaraghy Mechanical, Automotive and Materials Engineering (MAME), University of Windsor, Windsor, ON, Canada

Toshiyuki Enomoto Department of Engineering, Osaka University, Osaka, Japan 
Huseyin Erdim The Boeing Company, Seattle, WA, USA

Kaan Erkorkmaz Mechanical and Mechatronics Engineering, University of Waterloo, Waterloo, ON, Canada

W. Tyler Estler National Institute of Standards and Technology, Estler Associates, Adamstown, MD, USA

Christopher J. Evans Mechanical Engineering and Engineering Science, The William States Lee College of Engineering, UNC Charlotte, Charlotte, NC, USA

Björn Falk Laboratory for Machine Tools and Production Engineering (WZL), RWTH Aachen University, Aachen, Germany

Fengzhou Fang State Key Laboratory of Precision Measuring Technology and Instruments, Centre of MicroNano Manufacturing Technology, Tianjin University, Tianjin, China

Centre of MicroNano Manufacturing Technology (MNMT-Dublin), University College Dublin, Dublin, Ireland

Gualtiero Fantoni Department of Civil and Industrial Engineering, University of PisaLargo Lucio Lazzarino, Pisa, Italy

Klaus Feldmann Institute for Factory Automation and Production Systems (FAPS), Friedrich-Alexander-University of Erlangen-Nuremberg (FAU), Nuremberg, Germany

Eleonora Ferraris Department of Mechanical Engineering, Production Engineering, Machine Design and Automation (PMA) Section, KU Leuven, Leuven, Belgium

Luigino Filice Department of Mechanical, Energy and Management Engineering, University of Calabria, Arcavacata di Rende (CS), Italy

Antonio Fiorentino Department of Mechanical and Industrial Engineering, University of Brescia, Brescia, Italy

Jörg Franke Institute for Factory Automation and Production Systems (FAPS), Friedrich-Alexander-University of Erlangen-Nuremberg (FAU), Nuremberg, Germany

Vikki Franke Stuttgart, Germany

Livan Fratini Innovazione Industriale e Digitale (DIID) - Ingegneria Chimica, Gestionale, Informatica, Meccanica, University of Palermo, Palermo, Italy

Javier Fuentes Berlin, Germany

Makoto Fujishima Mori Seiki Company, Aichi, Japan

Apostolos Fysikopoulos Laboratory for Manufacturing Systems and Automation (LMS), Department of Mechanical Engineering and Aeronautics, University of Patras, Patras, Greece 
Automation Systems - Materials and Process Technologies, COMAU SpA, Grugliasco, Italy

L. Galdos Mechanical and Industrial Manufacturing Department, Mondragon University, Mondragón, Spain

Robert X. Gao Case Western Reserve University, Cleveland, OH, USA

Wei Gao Precision Nanometrology Laboratory, Department of Finemechanics, Tohoku University, Sendai, Japan

Andreas Gebhardt GoetheLab for Additive Manufacturing, FH Aachen University of Applied Sciences, Aachen, Germany

Michael Gerstenmeyer Institute of Production Science (wbk), Karlsruhe Institute of Technology (KIT), Karlsruhe, Germany

Christoph Gey Kennametal Shared Services GmbH, Fürth, Germany

Andrea. Ghiotti Department of Industrial Engineering, University of Padova, Padova, Italy

Claudio Giardini Department of Engineering, University of Bergamo, Bergamo, Italy

Daniel Graef Institute for Factory Automation and Production Systems (FAPS), Friedrich-Alexander-University of Erlangen-Nuremberg (FAU), Nuremberg, Germany

Josef Greitemann Institute for Machine Tools and Industrial Management (iwb), Technical University of Munich (TUM), Garching, Germany

Peter Groche Institute for Production Engineering and Forming Machines, Technische Universität Darmstadt, Darmstadt, Germany

Markus Groppe Sandvik Coromant GmbH, Düsseldorf, Germany

Wit Grzesik Department of Manufacturing Engineering and Production Automation, Opole University of Technology, Opole, Poland

Peihua Gu Department of Mechanical and Manufacturing Engineering, University of Calgary, Calgary, AB, Canada

Han Haitjema Mitutoyo RCE, Best, The Netherlands

KU Leuven, Department of Mechanical Engineering, Leuven, Belgium

Adam Hansel Mori Seiki Company, Aichi, Japan

Fukuo Hashimoto Advanced Finishing Technology Ltd., Akron, OH, USA

Michael Z. Hauschild Department of Management Engineering, Division of Quantitative Sustainability Assessment, Technical University of Denmark, Lyngby, Denmark

Robert Heinemann School of Mechanical, Aerospace and Civil Engineering, The University of Manchester, Manchester, UK 
Carsten Heinzel IWT, MAPEX Center for Materials and Processes Bremen, University of Bremen, Bremen, Germany

Jan Henjes Production and Logistics Management, Fraunhofer Austria Research GmbH, Wien, Austria

Alexander Hensel Institute for Factory Automation and Production Systems (FAPS), Friedrich-Alexander-University of Erlangen-Nuremberg (FAU), Nuremberg, Germany

Christoph Herrmann TU Braunschweig, Braunschweig, Germany

Konrad Herrmann Surface Metrology, Physikalisch-Technische Bundesanstalt (PTB), Braunschweig, Germany

Gerhard Hirt Institut für Bildsame Formgebung (ibf), Aachen, Germany

Jan-Steffen Hoetter FH-Aachen/University of Applied Sciences, Aachen, Germany

Hans-Werner Hoffmeister Institute of Machine Tools and Production Technology, TU Braunschweig, Braunschweig, Germany

Johannes Hörber Neotech AMT GmbH, Nuernberg, Germany

S. Jack Hu Department of Mechanical Engineering, University of Michigan, Ann Arbor, MI, USA

Margot Hutchins Sandia National Laboratories, Livermore, CA, USA

Juan Manuel Jauregui-Becker Laboratory of Design, Production and Management, University of Twente, Enschede, The Netherlands

I. S. Jawahir Institute for Sustainable Manufacturing, College of Engineering, University of Kentucky, Lexington, KY, USA

Jack Jeswiet Department of Mechanical and Materials Engineering, Queens University, Kingston, ON, Canada

Xiangqian Jiang Centre for Precision Technologies, University of Huddersfield, Huddersfield, UK

Roger J. Jiao The George M. Woodruff School of Mechanical Engineering, Georgia Institute of Technology, Atlanta, GA, USA

Francesco Jovane Dipartimento di Meccanica, Politecnico di Milano, Milan, Italy

Bingfeng Ju Department of Mechanical Engineering, Zhejiang University, Hangzhou, China

Sami Kara School of Mechanical and Manufacturing Engineering, The University of New South Wales, Sydney, NSW, Australia

Bernhard Karpuschewski University of Bremen, Faculty of Production Engineering, Bremen, Germany 
Leibniz Institute for Materials Engineering IWT, Division Manufacturing Technology, Bremen, Germany

Christopher Kästle Institute for Factory Automation and Production Systems (FAPS), Friedrich-Alexander-University of Erlangen-Nuremberg (FAU), Nuremberg, Germany

Karel Kellens Department of Mechanical Engineering, Centre for Industrial Management, KU Leuven, Leuven, Belgium

Sang-Gook Kim Mechanical Engineering, Massachusetts Institute of Technology, Cambridge, MA, USA

Tae Hyung Kim Signal and Image Processing Institute, Biomedical Imaging Group, University of Southern California, Los Angeles, CA, USA

Benjamin Kirsch FBK - Institute for Manufacturing Technology and Production Systems, University of Kaiserslautern, Kaiserslautern, Germany

Hossam A. Kishawy Department of Automotive, Mechanical and Manufacturing Engineering, Faculty of Engineering and Applied Science, University of Ontario Institute of Technology (UOIT), Oshawa, ON, Canada

Andreas Klink Laboratory for Machine Tools and Production Engineering, RWTH Aachen University, Aachen, Germany

Inge Klobasa Renewables Certification, DNV GL, Hamburg, Germany

Fritz Klocke Laboratory for Machine Tools and Production Engineering (WZL), RWTH Aachen University, Aachen, Germany

Alexander Klumpp Institute for Applied Materials (IAM-WK), Karlsruhe Institute of Technology (KIT), Karlsruhe, Germany

Wolfgang Knapp IWF, ETH Zurich, Schleitheim, Switzerland

Ludger Koenders Surface Metrology, Physikalisch-Technische Bundesanstalt (PTB), Braunschweig, Germany

Jens Köhler ProWerk GmbH, Wedemark/Hannover, Germany

Ralf Kolleck Institute of Tools and Forming, Graz University of Technology, Graz, Austria

Carol Kong Advanced Manufacturing Centre, School of Engineering, University of Birmingham, Birmingham, UK

Yoram Koren J.J. Duderstadt Distinguished University Professor, NSF Center for Reconfigurable Manufacturing Systems, The University of Michigan, Ann Arbor, MI, USA

Peter Krajnik Department of Industrial and Materials Science, Chalmers University of Technology, Gothenburg, Sweden

Jörg Krüger Industrial Automation Technology, Institute for Machine Tools and Factory Management (IWF), Berlin, Germany 
Michal Kuffa Institut für Werkzeugmaschinen und Fertigung (IWF), ETH Zürich, Zürich, Switzerland

Thomas Kuhn Institute for Factory Automation and Production Systems (FAPS), Friedrich-Alexander-University of Erlangen-Nuremberg (FAU), Nuremberg, Germany

Fredy Kuster Institute for Machine Tools and Manufacturing, ETH Zürich, Zürich, Switzerland

Henning Lagemann Fakultät für Maschinenbau/Lehrstuhl für Produktionssysteme, Ruhr-University Bochum, Bochum, Germany

Min Lai State Key Laboratory of Precision Measuring Technology and Instruments, Centre of MicroNano Manufacturing Technology, Tianjin University, Tianjin, China

Dirk Landgrebe Fraunhofer Institute for Machine Tools and Forming Technology IWU, Chemnitz, Germany

Gisela Lanza Institute of Production Science (wbk), Karlsruhe Institute of Technology (KIT), Karlsruhe, Germany

Luc Laperrière Mechanical Engineering, Université du Québec à TroisRivières, Trois-Rivières, QC, Canada

Bert Lauwers Department of Mechanical Engineering, KU Leuven, Heverlee, Belgium

Seyed Ehsan Layegh Khavidaki Mechanical Engineering Department, Koç University, Manufacturing and Automation Research Center, Istanbul, Turkey

Ismail Lazoglu Koç University, Istanbul, Turkey

Richard Leach Department of Mechanical, Materials and Manufacturing Engineering, University of Nottingham, Nottingham, UK

Armin Lechler Institut für Steuerungstechnik der Werkzeugmaschinen und Fertigungseinrichtungen (ISW), Universität Stuttgart, Stuttgart, Germany

Ming C. Leu Department of Mechanical and Aerospace Engineering, Missouri University of Science and Technology, Rolla, Missouri, USA

Terje K. Lien Department of Mechanical and Industrial Engineering, NTNU - Norwegian University of Science and Technology, Trondheim, Norway

Mathias Liewald Institute for Metal Forming Technology, University of Stuttgart, Stuttgart, Germany

Barbara Linke Mechanical and Aerospace Engineering, University of California Davis, Davis, CA, USA

James Lucas Department of Electrical Engineering and Electronics, University of Liverpool, Liverpool, UK 
Dieter Lung Cutting Technology, WZL, RWTH Aachen University, Aachen, Germany

Rocco Lupoi Department of Mechanical and Manufacturing Engineering, Parsons Building, Trinity College Dublin, The University of Dublin, Dublin, Ireland

Eric Lutters Faculty of Engineering Technology, Department of Design, Production and Management, University of Twente, Enschede, The Netherlands

Morten Hannibal Madsen Topsil GlobalWafers A/S, Frederikssund, Denmark

Sotiris Makris Laboratory for Manufacturing Systems and Automation (LMS), Department of Mechanical Engineering and Aeronautics, University of Patras, Patras, Greece

Ajay Malshe Manufacturing Processes, and Integrated Systems, University of Arkansas, College of Engineering, Arkansas, USA

Ali Mamedov Mechanical Engineering Department, Koç University, Manufacturing and Automation Research Center, Istanbul, Turkey

Francesco Marinello TESAF, Dipartimento Territorio e Sistemi AgroForestali, University of Padova, Legnaro, Italy

Kristian Martinsen Department of Manufacturing and Civil Engingeering, Department of Technology, Economy and Leadership, Norwegian University of Science and Technology, Gjøvik, Norway

Paul Mativenga School of Mechanical, Aerospace and Civil Engineering (MACE), The University of Manchester, Manchester, UK

René Mayer Department of Mechanical Engineering, Polytechnique Montréal, Montreal, Canada

Joseph Anthony McGeough School of Engineering, University of Edinburgh, Edinburgh, UK

Horst Meier Fakultät für Maschinenbau/Lehrstuhl für Produktionssysteme, Ruhr-University Bochum, Bochum, Germany

Jan-Fabian Meis Verein der Freunde und Förderer des Instituts für Werkzeugmaschinen und Betriebswissenschaften der TU München (iwb e.V.), Garching, Germany

Marion Merklein LFT, Institute of Manufacturing Technology, FriedrichAlexander-Universität Erlangen-Nürnberg, Erlangen, Germany

Nikolaos Michailidis Physical Metallurgy Laboratory (PML), Department of Mechanical Engineering, Aristotle University of Thessaloniki, Thessaloniki, Greece

Center for Research and Development on Advanced Materials - CERDAM, Thessaloniki, Greece 
George Michalos Laboratory for Manufacturing Systems and Automation (LMS), Department of Mechanical Engineering and Aeronautics, University of Patras, Patras, Greece

Hans-Christian Möhring Institute for Machine Tools, University of Stuttgart, Stuttgart, Germany

Andreas Moltesen Danish Energy Agency, Copenhagen, Denmark

Laszlo Monostori Laboratory of Engineering and Management Intelligence, Research Institute for Computer Science and Control, Hungarian Academy of Sciences, Budapest, Hungary

Department of Manufacturing Science and Technology, Budapest University of Technology and Economics, Budapest, Hungary

Karla P. Monroy Vazquez Engineering Group in Product, Process and Production, University of Girona, Girona, Spain

Masahiko Mori Mori Seiki Company, Aichi, Japan

Dimitris Mourtzis Laboratory for Manufacturing Systems and Automation (LMS), Department of Mechanical Engineering and Aeronautics, University of Patras, Patras, Greece

Khumbulani Mpofu Department of Industrial Engineering, Tshwane University of Technology, Pretoria West, South Africa

Omer Music Mechanical Engineering Department, TED University, Ankara, Turkey

Aydin Nassehi Department of Mechanical Engineering, University of Bristol, Bristol, UK

André Neumeister DREVE ProDiMed GmbH, Unna, Germany

Michael Niehues Institute for Machine Tools and Industrial Management (iwb), Technical University of Munich (TUM), Garching, Germany

Loring Nies Civil Engineering, Purdue University, West Lafayette, IN, USA

Peter Nyhuis Institut für Fabrikanlagen und Logistik, Leibniz Universität Hannover, Garbsen, Deutschland

Garret O'Donnell Mechanical and Manufacturing Engineering, Trinity College Dublin, Dublin, Ireland

Akira Okada Department of Mechanical Engineering, Okayama University, Okayama, Japan

Katherine Ortegon Industrial Engineering, Universidad Icesi, Cali, Valle, Colombia

Ecological Sciences and Engineering, Purdue University, West Lafayette, IN, USA

Jose Outeiro Arts et Metiers, Campus of Cluny, Cluny, France 
Ludger Overmeyer Institute of Transport and Automation Technology, Leibniz University Hannover, Garbsen, Germany

Claudia Pagano Institute of Industrial Technologies and Automation, Consiglio Nazionale delle Ricerche, Milan, Italy

Kenny Pagel Fraunhofer Institute for Machine Tools and Forming Technology IWU, Chemnitz, Germany

Sirko Pamin Laser Zentrum Hannover e.V., Hannover, Germany

Nikolaos Papakostas School of Mechanical and Materials Engineering, University College Dublin, Dublin, Ireland

John Paralikas Laboratory for Manufacturing Systems and Automation (LMS), Department of Mechanical Engineering and Aeronautics, University of Patras, Patras, Greece

Henri Paris Université Grenoble Alpes, GSCOP Laboratoire des Sciences pour la Conception, l'Optimisation et la Production de Grenoble, Grenoble, France

Jef R. Peeters Department of Mechanical Engineering, Centre for Industrial Management, KU Leuven, Leuven, Belgium

Gianluca Percoco Politecnico di Bari, Bari, Italy

Nicolas Perry $\mathrm{I} 2 \mathrm{M}$ - Mechanical and Engineering Institute of Bordeaux, Art et Métiers ParisTech, Talance, France

Steven Peters Institute of Production Science (wbk), Karlsruhe Institute of Technology (KIT), Karlsruhe, Germany

Michael Pfeffer Institute for Factory Automation and Production Systems (FAPS), Friedrich-Alexander-University of Erlangen-Nuremberg (FAU), Nuremberg, Germany

Fabio Jose Pinheiro Sousa Mechanical Engineering, University of Kaiserslautern FBK, Kaiserslautern, Rheinland-Pfalz, Germany

George Pintzos Laboratory for Manufacturing Systems and Automation (LMS), Department of Mechanical Engineering and Aeronautics, University of Patras, Patras, Greece

James A. Polyblank Department of Engineering, Cambridge University, Cambridge, UK

Mohammad Rabiey Mechanical Engineering, University of Applied Science Rapperswill, Rapperswill, Switzerland

Amir Rashid Department of Production Engineering, KTH Royal Institute of Technology, Stockholm, Sweden

Miriam Rauer Packaging and Interconnection Laboratory, Aschaffenburg University of Applied Sciences, Aschaffenburg, Germany 
Ingo Reichenbach FBK - Institute for Manufacturing Technology and Production Systems, University of Kaiserslautern, Kaiserslautern, Germany

Gunther Reinhart Institute for Machine Tools and Industrial Management (iwb), Technical University of Munich (TUM), Garching, Germany

Rüdiger Rentsch Leibniz IWT, Bremen, Germany

Loukas Rentzos Laboratory for Manufacturing Systems and Automation (LMS), Department of Mechanical Engineering and Aeronautics, University of Patras, Patras, Greece

Sebastian Richarz Berlin, Germany

Kim Rouven Riedmüller Institute for Metal Forming Technology, University of Stuttgart, Stuttgart, Germany

Michael Rusch Chair for Mechanical Design and Manufacturing, BTU Cottbus-Senftenberg, Cottbus, Germany

Konstantinos Salonitis Manufacturing Department, Cranfield University, Cranfield, UK

Fiona Sammler Berlin, Germany

Marco Santochi Department of Civil and Industrial Engineering, University of PisaLargo Lucio Lazzarino, Pisa, Italy

Enrico Savio Department of Industrial Engineering, University of Padova, Padova, Italy

Michael Schmidt Institute of Photonic Technologies, Friedrich-AlexanderUniversity Erlangen-Nuremberg, Erlangen, Germany

Erlangen Graduate School in Advanced Optical Technologies (SAOT), Friedrich-Alexander-University Erlangen-Nuremberg, Erlangen, Germany

Bayerisches Laserzentrum GmbH, Erlangen, Germany

Robert Schmitt Laboratory for Machine Tools and Production Engineering (WZL), RWTH Aachen University, Aachen, Germany

Bernd Scholz-Reiter Department of Planning and Control of Production Systems, University of Bremen and BIBA, Bremen, Germany

Paul Schönsleben Betriebswissenschaft, ETH Zürich, Zürich, Switzerland

Günther Schuh Forschungsinstitut für Rationalisierung (FIR) e. V, RWTH Aachen, Aachen, Germany

Volker Schulze Institute of Production Science (wbk), Karlsruhe Institute of Technology (KIT), Karlsruhe, Germany

Institute for Applied Materials (IAM-WK), Karlsruhe Institute of Technology (KIT), Karlsruhe, Germany

Viktor Schütz LG Technology Center Europe (LG Electronics EU Office), Düsseldorf, Germany 
Paul J. Scott Centre for Precision Technologies, University of Huddersfield, Huddersfield, UK

Tiziana Segreto Department of Chemical, Materials and Industrial Production Engineering (DICMAPI), University of Naples Federico II, Naples, Italy Fraunhofer Joint Laboratory of Excellence on Advanced Production Technology (Fh J_LEAPT), Naples, Italy

Günther Seliger Institut für Werkzeugmaschinen und Fabrikbetrieb Montagetechnik und Fabrikbetrieb, Technische Universität Berlin, Berlin, Germany

Burak Sencer College of Engineering, Oregon State University, Corvallis, OR, USA

Stefan Senge Institut für Bildsame Formgebung (ibf), Aachen, Germany

Eiji Shamoto Mechanical and Aerospace Engineering, Nagoya University, Nagoya, Japan

Hidenori Shinno Laboratory for Future Interdisciplinary Research of Science and Technology (FIRST), Tokyo Institute of Technology, Yokohama, Japan

L. H. Shu Mechanical and Industrial Engineering, University of Toronto, Toronto, ON, Canada

E. Silvestre Processing Lines and Rolling Mills, Fagor Arrasate S. Coop., Mondragón, Spain

Georgios Skordaris Laboratory for Machine Tools and Manufacturing Engineering and Fraunhofer Project Center Coatings in Manufacturing (PCCM)/ Mechanical Engineering Department, Aristoteles University of Thessaloniki, Thessaloniki, Greece

Jens Sölter Manufacturing Technologies, Leibniz Institute for Materials Engineering IWT, Bremen, Germany

Manufacturing Technologies, University of Bremen, MAPEX Center for Materials and Processes, Bremen, Germany

Celal Soyarslan Chair of Solid Mechanics, School of Mechanical Engineering and Safety Engineering, University of Wuppertal, Wuppertal, Germany

Dieter Spath Institute of Human Factors and Technology Management Institute Fraunhofer IAO (Fraunhofer Gesellschaft), University of Stuttgart, Stuttgart, Germany

Vijay Srinivasan Systems Integration Division, Engineering Laboratory, National Institute of Standards and Technology, Gaithersburg, MD, USA

Jens Stahl Institute of Metal Forming and Casting, Technische Universität München, Garching, Germany

Giuseppe Stecca IASI - CNR, Institute for Systems Analysis and Computer Science, National Research Council, Rome, Italy 
Gabor Stepan Department of Applied Mechanics, Budapest University of Technology and Economics, Budapest, Hungary

Andreas Sterzing Fraunhofer Institute for Machine Tools and Forming Technology (IWU), Chemnitz, Germany

Tobias Surmann Premium AEROTEC GmbH, Varel, Germany

Mechanical Engineering, Technical University of Dortmund ISF, Dortmund, Germany

John W. Sutherland Environmental and Ecological Engineering, Purdue University, West Lafayette, IN, USA

Alexander Sviridov Chair for Mechanical Design and Manufacturing, BTU Cottbus-Senftenberg, Cottbus, Germany

Aarief Syed-Khaja Institute for Factory Automation and Production Systems (FAPS), Friedrich-Alexander-University of Erlangen-Nuremberg (FAU), Nuremberg, Germany

Heraeus Electronics, Heraeus Deutschland GmbH \& Co. KG, Hanau, Germany

A. Erman Tekkaya Institute of Forming Technology and Lightweight Construction, Technische Universität Dortmund, Dortmund, Germany

Roberto Teti Department of Chemical, Materials and Industrial Production Engineering (DICMAPI), University of Naples Federico II, Naples, Italy

Fraunhofer Joint Laboratory of Excellence on Advanced Production Technology (Fh J_LEAPT), Naples, Italy

Sebastian Thiede TU Braunschweig/IWF, Braunschweig, Germany

Hans Kurt Toenshoff Institute of Production Engineering and Machine Tools, Leibniz University Hannover, Garbsen, Germany

Tullio Tolio ITIA Institute of Industrial Technologies and Automation, CNR National Research Council, Milan, Italy

Guido Tosello Department of Mechanical Engineering, Technical University of Denmark, Kongens Lyngby, Denmark

Mitchell M. Tseng Feng Chia University, Taichung, Taiwan

The Hong Kong University of Science and Technology, Hong Kong, China

Kanji Ueda The University of Tokyo, Kashiwa, Chiba, Japan

Takashi Ueda Department of Mechanical Science and Engineering, Nagoya University, Nagoya, Aichi, Japan

Eckart UhImann Fraunhofer Institute for Production Systems and Design Technology, Berlin, Germany

Domenico Umbrello Department of Mechanical, Energy and Management Engineering, University of Calabria, Arcavacata di Rende (CS), Italy 
Yasushi Umeda Department of Precision Engineering, School of Engineering, The University of Tokyo, Tokyo, Japan

Marcello Urgo Dipartimento di Meccanica, Sezione Tecnologie Meccaniche e Produzione, Politecnico di Milano, Milan, Italy

Luis Uriarte IK4-Tekniker, Eibar, Spain

Hendrik Van Brussel Mechanical Engineering, KU Leuven, Heverlee (Leuven), Belgium

Anna Valente ISTePS, Institute of Systems and Technologies for Sustainable Production, SUPSI- University of Applied Sciences and Arts of Italian Switzerland, Manno, Italy

József Váncza Research Laboratory of Engineering and Management Intelligence, Institute for Computer Science and Control, Hungarian Academy of Sciences, Budapest, Hungary

Paul Vanegas Department of Mechanical Engineering, Centre for Industrial Management, KU Leuven, Leuven, Belgium

Faculty of Engineering, University of Cuenca, Cuenca, Ecuador

Tom Vaneker University of Twente, Enschede, The Netherlands

Frederik Vits Research Area Manufacturing Technology - Research Group Grinding, Laboratory for Machine Tools and Production Engineering (WZL) of RWTH Aachen University, Aachen, Germany

Wolfram Volk Institute of Metal Forming and Casting, Technische Universität München, Garching, Germany

Toshiaki Wakabayashi Faculty of Engineering, Kagawa University, Takamatsu, Kagawa, Japan

Christian Walter Institut für Werkzeugmaschinen und Fertigung (IWF), ETH Zürich, Zürich, Switzerland

Yixiao Wang Institute of Transport and Automation Technology, Leibniz University Hannover, Garbsen, Germany

Yue Wang Hang Seng Management College, Hong Kong, China

John A. Webster Cool-Grind Technologies Connecticut USA, Storrs Mansfield, CT, USA

Albert A. Weckenmann Quality Management and Manufacturing Metrology, University Erlangen-Nuremberg, Erlangen, Germany

Konrad Wegener Institut für Werkzeugmaschinen und Fertigung (IWF), ETH Zürich, Zürich, Switzerland

Eduardo Weingärtner New Manufacturing Technologies, ETA SA Manufacture Horlogère Suisse, Grenchen, Switzerland 
Rafael Wertheim Fraunhofer Institute for Machine Tools and Forming Technology IWU, Chemnitz, Germany

Engelbert Westkämper Fraunhofer-Institute IPA, University Stuttgart Graduate School for Advanced Manufacturing Engineering, Stuttgart, Germany

Hans-Peter Wiendahl Institut für Fabrikanlagen und Logistik, University of Hannover, Hannover, Germany

Katja Windt Global Production Logistics, School of Engineering and Science, Jacobs University, Bremen, Germany

Tim Wolfer Institute of Transport and Automation Technology, Leibniz University Hannover, Garbsen, Germany

Z. Cedric Xia Research and Innovation Center, Ford Motor Company, Dearborn, MI, USA

Ping Xu Institute for Factory Automation and Production Systems (FAPS), Friedrich-Alexander-University of Erlangen-Nuremberg (FAU), Nuremberg, Germany

Zong Wei Xu College of Precision Instrument and Opto-Electronic Engineering, Centre of MicroNano Manufacturing Technology, Tianjin University, Tianjin, China

José A. Yagüe-Fabra Design and Manufacturing Engineering, Universidad de Zaragoza Instituto de Investigación en Ingeniería de Aragón (I3A), Zaragoza, Spain

Hitomi Yamaguchi Mechanical and Aerospace Engineering, University of Florida, Gainesville, FL, USA

Jun Yanagimoto Institute of Industrial Science, The University of Tokyo, Tokyo, Japan

Andreas Zabel Institute of Machining Technology (ISF), TU Dortmund University, Dortmund, Germany

Michael F. Zaeh iwb - Institut fuer Werkzeugmaschinen und Betriebswissenschaften, Technical University of Muenchen, Munich, Germany

Mikel Zatarain IK4-Ideko, Elgoibar, Gipuzkoa, Spain

Nan Zhang The State Key Laboratory of Precision Measuring Technology and Instruments, Centre of MicroNano Manufacturing Technology, Tianjin University, Tianjin, China

Centre of MicroNano Manufacturing Technology (MNMT-Dublin), University College Dublin, Dublin, Ireland

Pengzhe Zhu State Key Laboratory of Precision Measuring Technology and Instruments, Centre of MicroNano Manufacturing Technology, Tianjin University, Tianjin, China 


\section{List of Abbreviations}

\begin{tabular}{|c|c|c|c|}
\hline Abbreviation & Explanation & Term & Section \\
\hline $3 \mathrm{DP}$ & Three-Dimensional Printing & Rapid Tooling & $\begin{array}{l}\text { Electrophysical and Chemical } \\
\text { Processes }\end{array}$ \\
\hline AACVD & $\begin{array}{l}\text { Aerosol-Assisted Chemical } \\
\text { Vapor Deposition }\end{array}$ & $\begin{array}{l}\text { Chemical Vapor Deposition } \\
\text { (CVD) }\end{array}$ & $\begin{array}{l}\text { Electrophysical and Chemical } \\
\text { Processes }\end{array}$ \\
\hline $\mathrm{ABC}$ & Activity-Based Costing & Cost & $\begin{array}{l}\text { Production Systems and } \\
\text { Organizations }\end{array}$ \\
\hline \multirow[t]{3}{*}{$\mathrm{AC}$} & \multirow[t]{3}{*}{ Alternating Current } & Brazing and Soldering & Assembly \\
\hline & & Coated Tools & Cutting \\
\hline & & $\begin{array}{l}\text { Physical Vapor Deposition } \\
\text { (PVD) }\end{array}$ & $\begin{array}{l}\text { Electrophysical and Chemical } \\
\text { Processes }\end{array}$ \\
\hline $\mathrm{AC}$ & Adaptive Control & Adaptive Control & Machines \\
\hline $\mathrm{ACE}$ & Automatic Computing Engine & Artificial Intelligence & $\begin{array}{l}\text { Production Systems and } \\
\text { Organizations }\end{array}$ \\
\hline \multirow[t]{2}{*}{$\mathrm{AD}$} & \multirow[t]{2}{*}{ Axiomatic Design } & Axiomatic Design & Design \\
\hline & & Design Methodology & Design \\
\hline ADC & Analog-to-Digital Converter & Sensor Assembly & Assembly \\
\hline ADI & Austempered Ductile Iron & $\begin{array}{l}\text { Machining of Spheroidal } \\
\text { Ductile Iron }\end{array}$ & Cutting \\
\hline ADRT & Actively Driven Rotary Tool & Turning with Rotary Tools & Cutting \\
\hline \multirow[t]{4}{*}{$\mathrm{AE}$} & \multirow[t]{4}{*}{ Acoustic Emission } & Grinding Burn & Abrasive Processes \\
\hline & & Grinding Machines & Abrasive Processes \\
\hline & & Grinding Monitoring & Abrasive Processes \\
\hline & & Crack Initiation & Surfaces \\
\hline AES & Auger Electron Spectroscopy & Surface Integrity & Cutting \\
\hline AFM & Abrasive Flow Machining & Finishing & Abrasive Processes \\
\hline \multirow[t]{3}{*}{ AFM } & \multirow[t]{3}{*}{ Atomic Force Microscopy } & Positioning & $\begin{array}{l}\text { Precision Engineering and } \\
\text { Metrology }\end{array}$ \\
\hline & & Nanotechnology & Surfaces \\
\hline & & Scatterometry & Surfaces \\
\hline \multirow[t]{4}{*}{$\mathrm{AGV}$} & \multirow[t]{4}{*}{ Automatic Guided Vehicle } & Handling & Assembly \\
\hline & & Material Flow & Assembly \\
\hline & & Complexity in Manufacturing & $\begin{array}{l}\text { Production Systems and } \\
\text { Organizations }\end{array}$ \\
\hline & & Manufacturing System & $\begin{array}{l}\text { Production Systems and } \\
\text { Organizations }\end{array}$ \\
\hline
\end{tabular}

(continued) 


\begin{tabular}{|c|c|c|c|}
\hline Abbreviation & Explanation & Term & Section \\
\hline \multirow[t]{2}{*}{ AHP } & \multirow[t]{2}{*}{ Analytic Hierarchy Process } & Decision-Making & Design \\
\hline & & Fuzzy Logic & $\begin{array}{l}\text { Production Systems and } \\
\text { Organizations }\end{array}$ \\
\hline \multirow[t]{3}{*}{ AI } & \multirow[t]{3}{*}{ Artificial Intelligence } & Artificial Intelligence & $\begin{array}{l}\text { Production Systems and } \\
\text { Organizations }\end{array}$ \\
\hline & & $\begin{array}{l}\text { Computer-Aided } \\
\text { Manufacturing }\end{array}$ & $\begin{array}{l}\text { Production Systems and } \\
\text { Organizations }\end{array}$ \\
\hline & & Cyber-Physical Systems & $\begin{array}{l}\text { Production Systems and } \\
\text { Organizations }\end{array}$ \\
\hline AIEDAM & $\begin{array}{l}\text { Artificial Intelligence for } \\
\text { Engineering Design, } \\
\text { Analysis, and Manufacturing }\end{array}$ & Function Modeling & Design \\
\hline \multirow[t]{3}{*}{$\mathrm{AM}$} & \multirow[t]{3}{*}{ Additive Manufacturing } & $\begin{array}{l}\text { Additive Manufacturing } \\
\text { Technologies }\end{array}$ & $\begin{array}{l}\text { Electrophysical and Chemical } \\
\text { Processes }\end{array}$ \\
\hline & & Rapid Tooling & $\begin{array}{l}\text { Electrophysical and Chemical } \\
\text { Processes }\end{array}$ \\
\hline & & Machine Tool & Machines \\
\hline AMF & $\begin{array}{l}\text { American Machine and } \\
\text { Foundry }\end{array}$ & Robot & Assembly \\
\hline AMR & $\begin{array}{l}\text { Anisotropic } \\
\text { Magnetoresistance }\end{array}$ & Sensor Assembly & Assembly \\
\hline \multirow[t]{2}{*}{ ANN } & \multirow[t]{2}{*}{ Artificial Neural Network } & Cost & $\begin{array}{l}\text { Production Systems and } \\
\text { Organizations }\end{array}$ \\
\hline & & Neural Network & $\begin{array}{l}\text { Production Systems and } \\
\text { Organizations }\end{array}$ \\
\hline ANOVA & Analysis of Variance & $\begin{array}{l}\text { Measurement System } \\
\text { Analysis }\end{array}$ & $\begin{array}{l}\text { Precision Engineering and } \\
\text { Metrology }\end{array}$ \\
\hline \multirow[t]{2}{*}{ ANSI } & \multirow{2}{*}{$\begin{array}{l}\text { American National Standards } \\
\text { Institute }\end{array}$} & Grinding Wheel & Abrasive Processes \\
\hline & & Tolerancing & Design \\
\hline AOI & Automated Optical Inspection & Optical Inspection & Assembly \\
\hline AOQL & $\begin{array}{l}\text { Average Outgoing Quality } \\
\text { Limit }\end{array}$ & Quality Assurance & $\begin{array}{l}\text { Precision Engineering and } \\
\text { Metrology }\end{array}$ \\
\hline $\mathrm{APC}$ & $\begin{array}{l}\text { Adaptive Production Planning } \\
\text { and Control }\end{array}$ & Changeable Manufacturing & $\begin{array}{l}\text { Production Systems and } \\
\text { Organizations }\end{array}$ \\
\hline APCVD & $\begin{array}{l}\text { Atmospheric Pressure } \\
\text { Chemical Vapor Deposition }\end{array}$ & $\begin{array}{l}\text { Chemical Vapor Deposition } \\
\text { (CVD) }\end{array}$ & $\begin{array}{l}\text { Electrophysical and Chemical } \\
\text { Processes }\end{array}$ \\
\hline API & $\begin{array}{l}\text { Application Programming } \\
\text { Interface }\end{array}$ & Open Architecture & Machines \\
\hline APT & Ammonium Paratungstate & Cemented Carbides & Cutting \\
\hline \multirow[t]{2}{*}{ APT } & \multirow[t]{2}{*}{$\begin{array}{l}\text { Automatically Programmed } \\
\text { Tool }\end{array}$} & $\begin{array}{l}\text { Five-Axis Tool Path } \\
\text { Generation }\end{array}$ & Cutting \\
\hline & & $\begin{array}{l}\text { Computer-Aided } \\
\text { Manufacturing }\end{array}$ & $\begin{array}{l}\text { Production Systems and } \\
\text { Organizations }\end{array}$ \\
\hline APTE & $\begin{array}{l}\text { Application des Techniques } \\
\text { d'Enterprise (fr); Application } \\
\text { of Corporation Methods (en) }\end{array}$ & Conceptual Design & Design \\
\hline AQL & Acceptable Quality Level & Quality Assurance & $\begin{array}{l}\text { Precision Engineering and } \\
\text { Metrology }\end{array}$ \\
\hline \multirow[t]{2}{*}{ AR } & \multirow[t]{2}{*}{ Augmented Reality } & Assembly Representation & Assembly \\
\hline & & Augmented Reality & Design \\
\hline
\end{tabular}




\begin{tabular}{|c|c|c|c|}
\hline Abbreviation & Explanation & Term & Section \\
\hline ARL & Average Run Length & Statistical Process Control & $\begin{array}{l}\text { Production Systems and } \\
\text { Organizations }\end{array}$ \\
\hline ASA & $\begin{array}{l}\text { American Standards } \\
\text { Association }\end{array}$ & Tolerancing & Design \\
\hline ASPE & $\begin{array}{l}\text { American Society for } \\
\text { Precision Engineering }\end{array}$ & Precision & $\begin{array}{l}\text { Precision Engineering and } \\
\text { Metrology }\end{array}$ \\
\hline ASRS & $\begin{array}{l}\text { Automated Storage and } \\
\text { Retrieval Systems }\end{array}$ & $\begin{array}{l}\text { Computer-Integrated } \\
\text { Manufacturing }\end{array}$ & $\begin{array}{l}\text { Production Systems and } \\
\text { Organizations }\end{array}$ \\
\hline ASU & Actuator-Sensor Unit & Actuator & Machines \\
\hline AVC & Active Vibration Control & Actuator & Machines \\
\hline AVDT & Average Downtime per failure & Assembly Line & Assembly \\
\hline AWC & Automatic Work Changers & Machine Tool & Machines \\
\hline AWJ & Abrasive Waterjet & Waterjet Cutting & Abrasive Processes \\
\hline AXI & Automated X-ray Inspection & Automated X-ray Inspection & Assembly \\
\hline BA & Bend Allowance & Bending (Sheets) & Forming \\
\hline BCA & $\begin{array}{l}\text { Binary Collision } \\
\text { Approximation }\end{array}$ & Ion Beam Machining & $\begin{array}{l}\text { Electrophysical and Chemical } \\
\text { Processes }\end{array}$ \\
\hline \multirow[t]{2}{*}{$\mathrm{BCC}$} & \multirow[t]{2}{*}{ Body-Centered Cubic } & High-Speed Cutting & Cutting \\
\hline & & Deformation (Dislocations) & Forming \\
\hline $\mathrm{BDC}$ & Bottom Dead Center & Thixoforming & Forming \\
\hline BGA & Ball Grid Array & Optical Inspection & Assembly \\
\hline $\mathrm{BHF}$ & Blank Holder Force & $\begin{array}{l}\text { Hydroforming (Sheets and } \\
\text { Tubes) }\end{array}$ & Forming \\
\hline BIPM & $\begin{array}{l}\text { Bureau International des } \\
\text { Poids et Mesures (fr); } \\
\text { International Bureau of } \\
\text { Weights and Measures }\end{array}$ & Metrology & $\begin{array}{l}\text { Precision Engineering and } \\
\text { Metrology }\end{array}$ \\
\hline $\mathrm{BN}$ & Barkhausen Noise & Grinding Burn & Abrasive Processes \\
\hline BNA & Barkhausen Noise Analysis & Surface Integrity & Cutting \\
\hline BOM & Bill of Material & $\begin{array}{l}\text { Cladistics for Products and } \\
\text { Manufacturing }\end{array}$ & $\begin{array}{l}\text { Production Systems and } \\
\text { Organizations }\end{array}$ \\
\hline $\mathrm{BON}$ & Bed of Nails & Electric Test & Assembly \\
\hline BPMN & $\begin{array}{l}\text { Business Process Model and } \\
\text { Notation }\end{array}$ & Operations Management & $\begin{array}{l}\text { Production Systems and } \\
\text { Organizations }\end{array}$ \\
\hline BPP & Beam Parameter Product & Laser Welding & Assembly \\
\hline BSD & Ball Screw Drives & Actuator & Machines \\
\hline BSE & Backscattered Electrons & $\begin{array}{l}\text { Scanning Electron } \\
\text { Microscope }\end{array}$ & $\begin{array}{l}\text { Precision Engineering and } \\
\text { Metrology }\end{array}$ \\
\hline B-spline & Basis Spline & $\begin{array}{l}\text { Five-Axis Tool Path } \\
\text { Generation }\end{array}$ & Cutting \\
\hline BTA & $\begin{array}{l}\text { Boring Trepanning } \\
\text { Association }\end{array}$ & Drilling & Cutting \\
\hline $\mathrm{C} \& \mathrm{CM}$ & Contact and Channel Model & Design Methodology & Design \\
\hline \multirow[t]{6}{*}{ CAD } & \multirow[t]{6}{*}{ Computer-Aided Design } & Assembly Representation & Assembly \\
\hline & & $\begin{array}{l}\text { Five-Axis Tool Path } \\
\text { Generation }\end{array}$ & Cutting \\
\hline & & $\begin{array}{l}\text { Geometric Modeling of } \\
\text { Machining }\end{array}$ & Cutting \\
\hline & & Computer-Aided Design & Design \\
\hline & & Information Management & Design \\
\hline & & Reverse Engineering & Design \\
\hline
\end{tabular}




\begin{tabular}{|c|c|c|c|}
\hline Abbreviation & Explanation & Term & Section \\
\hline & & Computer Numerical Control & Machines \\
\hline & & $\begin{array}{l}\text { Geometrical Product } \\
\text { Specification }\end{array}$ & $\begin{array}{l}\text { Precision Engineering and } \\
\text { Metrology }\end{array}$ \\
\hline & & $\begin{array}{l}\text { Computer-Aided } \\
\text { Manufacturing }\end{array}$ & $\begin{array}{l}\text { Production Systems and } \\
\text { Organizations }\end{array}$ \\
\hline & & $\begin{array}{l}\text { Computer-Integrated } \\
\text { Manufacturing }\end{array}$ & $\begin{array}{l}\text { Production Systems and } \\
\text { Organizations }\end{array}$ \\
\hline & & Cooperative Engineering & $\begin{array}{l}\text { Production Systems and } \\
\text { Organizations }\end{array}$ \\
\hline & & Cyber-Physical Systems & $\begin{array}{l}\text { Production Systems and } \\
\text { Organizations }\end{array}$ \\
\hline & & Manufacturing System & $\begin{array}{l}\text { Production Systems and } \\
\text { Organizations }\end{array}$ \\
\hline & & Freeform & Surfaces \\
\hline CAE & Computer-Aided Engineering & $\begin{array}{l}\text { Computer-Aided } \\
\text { Manufacturing }\end{array}$ & $\begin{array}{l}\text { Production Systems and } \\
\text { Organizations }\end{array}$ \\
\hline \multirow[t]{8}{*}{ CAM } & \multirow[t]{8}{*}{$\begin{array}{l}\text { Computer-Aided } \\
\text { Manufacturing }\end{array}$} & $\begin{array}{l}\text { Five-Axis Tool Path } \\
\text { Generation }\end{array}$ & Cutting \\
\hline & & Computer-Aided Design & Design \\
\hline & & Information Management & Design \\
\hline & & Computer Numerical Control & Machines \\
\hline & & $\begin{array}{l}\text { Computer-Aided } \\
\text { Manufacturing }\end{array}$ & $\begin{array}{l}\text { Production Systems and } \\
\text { Organizations }\end{array}$ \\
\hline & & $\begin{array}{l}\text { Computer-Integrated } \\
\text { Manufacturing }\end{array}$ & $\begin{array}{l}\text { Production Systems and } \\
\text { Organizations }\end{array}$ \\
\hline & & Cooperative Engineering & $\begin{array}{l}\text { Production Systems and } \\
\text { Organizations }\end{array}$ \\
\hline & & Manufacturing System & $\begin{array}{l}\text { Production Systems and } \\
\text { Organizations }\end{array}$ \\
\hline \multirow[t]{5}{*}{ CAPP } & \multirow[t]{5}{*}{$\begin{array}{l}\text { Computer-Aided Process } \\
\text { Planning }\end{array}$} & $\begin{array}{l}\text { Chip-forms, Chip } \\
\text { Breakability and Chip Control }\end{array}$ & Cutting \\
\hline & & $\begin{array}{l}\text { Computer-Aided } \\
\text { Manufacturing }\end{array}$ & $\begin{array}{l}\text { Production Systems and } \\
\text { Organizations }\end{array}$ \\
\hline & & $\begin{array}{l}\text { Computer-Aided Process } \\
\text { Planning }\end{array}$ & $\begin{array}{l}\text { Production Systems and } \\
\text { Organizations }\end{array}$ \\
\hline & & $\begin{array}{l}\text { Computer-Integrated } \\
\text { Manufacturing }\end{array}$ & $\begin{array}{l}\text { Production Systems and } \\
\text { Organizations }\end{array}$ \\
\hline & & Manufacturing & $\begin{array}{l}\text { Production Systems and } \\
\text { Organizations }\end{array}$ \\
\hline CAS & Complex Adaptive Systems & Cyber-Physical Systems & $\begin{array}{l}\text { Production Systems and } \\
\text { Organizations }\end{array}$ \\
\hline CASA & $\begin{array}{l}\text { Computer and Automated } \\
\text { Systems Association }\end{array}$ & $\begin{array}{l}\text { Computer-Integrated } \\
\text { Manufacturing }\end{array}$ & $\begin{array}{l}\text { Production Systems and } \\
\text { Organizations }\end{array}$ \\
\hline CAT & Computer-Aided Testing & $\begin{array}{l}\text { Computer-Integrated } \\
\text { Manufacturing }\end{array}$ & $\begin{array}{l}\text { Production Systems and } \\
\text { Organizations }\end{array}$ \\
\hline \multirow[t]{5}{*}{$\mathrm{CBN}$} & \multirow[t]{5}{*}{ Cubic Boron Nitride } & Abrasive Material & Abrasive Processes \\
\hline & & $\begin{array}{l}\text { Bonding Materials for } \\
\text { Abrasive Tools }\end{array}$ & Abrasive Processes \\
\hline & & Creep-Feed Grinding & Abrasive Processes \\
\hline & & Electrochemical Dressing & Abrasive Processes \\
\hline & & Gear Grinding & Abrasive Processes \\
\hline
\end{tabular}




\begin{tabular}{|c|c|c|c|}
\hline Abbreviation & Explanation & Term & Section \\
\hline & & Grinding Tool Structuring & Abrasive Processes \\
\hline & & Grinding Wheel & Abrasive Processes \\
\hline & & $\begin{array}{l}\text { High-Performance Dry } \\
\text { Grinding }\end{array}$ & Abrasive Processes \\
\hline & & High-Performance Grinding & Abrasive Processes \\
\hline & & Superabrasives & Abrasive Processes \\
\hline & & Ultraprecision Grinding & Abrasive Processes \\
\hline & & Waterjet Cutting & Abrasive Processes \\
\hline & & Cemented Carbides & Cutting \\
\hline & & Ceramic Cutting Tools & Cutting \\
\hline & & Cermets & Cutting \\
\hline & & Composite Materials & Cutting \\
\hline & & Cutting Temperature & Cutting \\
\hline & & $\begin{array}{l}\text { Machining of Spheroidal } \\
\text { Ductile Iron }\end{array}$ & Cutting \\
\hline & & Superhard Tools & Cutting \\
\hline \multirow[t]{2}{*}{ CBR } & \multirow[t]{2}{*}{ Case-Based Reasoning } & Decision-Making & Design \\
\hline & & Cost & $\begin{array}{l}\text { Production Systems and } \\
\text { Organizations }\end{array}$ \\
\hline CBS & Cost Breakdown Structure & Life Cycle Cost & Life Cycle Engineering \\
\hline CCD & Charge-Coupled Device & Resolution & $\begin{array}{l}\text { Precision Engineering and } \\
\text { Metrology }\end{array}$ \\
\hline \multirow[t]{2}{*}{$\mathrm{CD}$} & \multirow[t]{2}{*}{ Continuous Dressing } & Creep-Feed Grinding & Abrasive Processes \\
\hline & & Dressing & Abrasive Processes \\
\hline $\mathrm{CE}$ & Cooperative Engineering & Cooperative Engineering & $\begin{array}{l}\text { Production Systems and } \\
\text { Organizations }\end{array}$ \\
\hline $\mathrm{CF}$ & Correction Factor & Cutting Force Modeling & Cutting \\
\hline CFC & Cubic Face-Centered & Hot Stamping & Forming \\
\hline CFD & $\begin{array}{l}\text { Computational Fluid } \\
\text { Dynamics }\end{array}$ & Mechatronics & Machines \\
\hline CFRP & $\begin{array}{l}\text { Carbon Fiber-Reinforced } \\
\text { Plastic }\end{array}$ & $\begin{array}{l}\text { Machinability of Carbon } \\
\text { Fiber-Reinforced and GLARE } \\
\text { Materials }\end{array}$ & Cutting \\
\hline CFT & Cross-Functional Teams & Cooperative Engineering & $\begin{array}{l}\text { Production Systems and } \\
\text { Organizations }\end{array}$ \\
\hline \multirow[t]{3}{*}{ CIM } & \multirow[t]{3}{*}{$\begin{array}{l}\text { Computer-Integrated } \\
\text { Manufacturing }\end{array}$} & $\begin{array}{l}\text { Computer-Integrated } \\
\text { Manufacturing }\end{array}$ & $\begin{array}{l}\text { Production Systems and } \\
\text { Organizations }\end{array}$ \\
\hline & & Cyber-Physical Systems & $\begin{array}{l}\text { Production Systems and } \\
\text { Organizations }\end{array}$ \\
\hline & & Manufacturing System & $\begin{array}{l}\text { Production Systems and } \\
\text { Organizations }\end{array}$ \\
\hline CIPM & $\begin{array}{l}\text { Comité International des } \\
\text { Poids et Mesures (fr); } \\
\text { International Committee for } \\
\text { Weights and Measures }\end{array}$ & Metrology & $\begin{array}{l}\text { Precision Engineering and } \\
\text { Metrology }\end{array}$ \\
\hline CIS & $\begin{array}{l}\text { Continuous In-Process } \\
\text { Sharpening }\end{array}$ & Creep-Feed Grinding & Abrasive Processes \\
\hline CLIP & $\begin{array}{l}\text { Continuous Liquid Interface } \\
\text { Production }\end{array}$ & $\begin{array}{l}\text { Additive Manufacturing } \\
\text { Technologies }\end{array}$ & $\begin{array}{l}\text { Electrophysical and Chemical } \\
\text { Processes }\end{array}$ \\
\hline $\mathrm{CMC}$ & Ceramic Matrix Composites & Composite Materials & Cutting \\
\hline
\end{tabular}




\begin{tabular}{|c|c|c|c|}
\hline Abbreviation & Explanation & Term & Section \\
\hline \multirow[t]{9}{*}{ CMM } & \multirow{9}{*}{$\begin{array}{l}\text { Coordinate Measuring } \\
\text { Machine }\end{array}$} & Tolerancing & Design \\
\hline & & Abbe Error/Offset & $\begin{array}{l}\text { Precision Engineering and } \\
\text { Metrology }\end{array}$ \\
\hline & & Accuracy & $\begin{array}{l}\text { Precision Engineering and } \\
\text { Metrology }\end{array}$ \\
\hline & & $\begin{array}{l}\text { Coordinate Measuring } \\
\text { Machine }\end{array}$ & $\begin{array}{l}\text { Precision Engineering and } \\
\text { Metrology }\end{array}$ \\
\hline & & Error & $\begin{array}{l}\text { Precision Engineering and } \\
\text { Metrology }\end{array}$ \\
\hline & & $\begin{array}{l}\text { Geometrical Product } \\
\text { Specification }\end{array}$ & $\begin{array}{l}\text { Precision Engineering and } \\
\text { Metrology }\end{array}$ \\
\hline & & Precision Positioning & $\begin{array}{l}\text { Precision Engineering and } \\
\text { Metrology }\end{array}$ \\
\hline & & Traceability & $\begin{array}{l}\text { Precision Engineering and } \\
\text { Metrology }\end{array}$ \\
\hline & & $\begin{array}{l}\text { Computer-Aided Process } \\
\text { Planning }\end{array}$ & $\begin{array}{l}\text { Production Systems and } \\
\text { Organizations }\end{array}$ \\
\hline CMOS & $\begin{array}{l}\text { Complementary Metal-Oxide- } \\
\text { Semiconductor }\end{array}$ & Resolution & $\begin{array}{l}\text { Precision Engineering and } \\
\text { Metrology }\end{array}$ \\
\hline CMP & $\begin{array}{l}\text { Chemical-Mechanical } \\
\text { Polishing }\end{array}$ & Polishing & Abrasive Processes \\
\hline CMS & Coordinate Measuring System & Coordinate Measuring & $\begin{array}{l}\text { Precision Engineering and } \\
\text { Metrology }\end{array}$ \\
\hline \multirow[t]{14}{*}{$\mathrm{CNC}$} & \multirow[t]{14}{*}{ Computer Numerical Control } & Wave Soldering & Assembly \\
\hline & & Computer-Aided Design & Design \\
\hline & & Adaptive Control & Machines \\
\hline & & Computer Numerical Control & Machines \\
\hline & & Control & Machines \\
\hline & & Machine Tool & Machines \\
\hline & & Open Architecture & Machines \\
\hline & & Capacity Planning & $\begin{array}{l}\text { Production Systems and } \\
\text { Organizations }\end{array}$ \\
\hline & & $\begin{array}{l}\text { Computer-Aided } \\
\text { Manufacturing }\end{array}$ & $\begin{array}{l}\text { Production Systems and } \\
\text { Organizations }\end{array}$ \\
\hline & & $\begin{array}{l}\text { Computer-Integrated } \\
\text { Manufacturing }\end{array}$ & $\begin{array}{l}\text { Production Systems and } \\
\text { Organizations }\end{array}$ \\
\hline & & Cyber-Physical Systems & $\begin{array}{l}\text { Production Systems and } \\
\text { Organizations }\end{array}$ \\
\hline & & $\begin{array}{l}\text { Flexible Manufacturing } \\
\text { System }\end{array}$ & $\begin{array}{l}\text { Production Systems and } \\
\text { Organizations }\end{array}$ \\
\hline & & Manufacturing System & $\begin{array}{l}\text { Production Systems and } \\
\text { Organizations }\end{array}$ \\
\hline & & Manufacturing & $\begin{array}{l}\text { Production Systems and } \\
\text { Organizations }\end{array}$ \\
\hline CNP & Contract Net Protocol & Scheduling & $\begin{array}{l}\text { Production Systems and } \\
\text { Organizations }\end{array}$ \\
\hline $\mathrm{CoA}$ & Center of Area & Fuzzy Logic & $\begin{array}{l}\text { Production Systems and } \\
\text { Organizations }\end{array}$ \\
\hline \multirow[t]{2}{*}{ CPFR } & \multirow{2}{*}{$\begin{array}{l}\text { Collaborative Planning, } \\
\text { Forecasting, and } \\
\text { Replenishment }\end{array}$} & $\begin{array}{l}\text { ERP Enterprise Resource } \\
\text { Planning }\end{array}$ & $\begin{array}{l}\text { Production Systems and } \\
\text { Organizations }\end{array}$ \\
\hline & & Supply Chain Management & $\begin{array}{l}\text { Production Systems and } \\
\text { Organizations }\end{array}$ \\
\hline
\end{tabular}




\begin{tabular}{|c|c|c|c|}
\hline Abbreviation & Explanation & Term & Section \\
\hline CPM & $\begin{array}{l}\text { Characteristics-Properties } \\
\text { Modeling }\end{array}$ & Design Methodology & Design \\
\hline \multirow[t]{2}{*}{ CPPS } & \multirow[t]{2}{*}{$\begin{array}{l}\text { Cyber-Physical Production } \\
\text { Systems }\end{array}$} & Cyber-Physical Systems & $\begin{array}{l}\text { Production Systems and } \\
\text { Organizations }\end{array}$ \\
\hline & & Production Networks & $\begin{array}{l}\text { Production Systems and } \\
\text { Organizations }\end{array}$ \\
\hline \multirow[t]{5}{*}{ CPS } & \multirow[t]{5}{*}{ Cyber-Physical Systems } & Smart Products & Design \\
\hline & & Cyber-Physical Systems & $\begin{array}{l}\text { Production Systems and } \\
\text { Organizations }\end{array}$ \\
\hline & & Knowledge-Based System & $\begin{array}{l}\text { Production Systems and } \\
\text { Organizations }\end{array}$ \\
\hline & & Manufacturing System & $\begin{array}{l}\text { Production Systems and } \\
\text { Organizations }\end{array}$ \\
\hline & & Manufacturing & $\begin{array}{l}\text { Production Systems and } \\
\text { Organizations }\end{array}$ \\
\hline \multirow[t]{2}{*}{ CRM } & \multirow{2}{*}{$\begin{array}{l}\text { Customer Relationship } \\
\text { Management }\end{array}$} & Information Management & Design \\
\hline & & $\begin{array}{l}\text { ERP Enterprise Resource } \\
\text { Planning }\end{array}$ & $\begin{array}{l}\text { Production Systems and } \\
\text { Organizations }\end{array}$ \\
\hline $\mathrm{CS}$ & Cold Spray & Cold Spray & $\begin{array}{l}\text { Electrophysical and Chemical } \\
\text { Processes }\end{array}$ \\
\hline CSCMP & $\begin{array}{l}\text { Council of Supply Chain } \\
\text { Management Professionals }\end{array}$ & Logistics & $\begin{array}{l}\text { Production Systems and } \\
\text { Organizations }\end{array}$ \\
\hline CSG & Constructive Solid Geometry & $\begin{array}{l}\text { Geometric Modeling of } \\
\text { Machining }\end{array}$ & Cutting \\
\hline CSI & $\begin{array}{l}\text { Coherence Scanning } \\
\text { Interferometry }\end{array}$ & Interferometry & $\begin{array}{l}\text { Precision Engineering and } \\
\text { Metrology }\end{array}$ \\
\hline CSM & $\begin{array}{l}\text { Competitive Sustainable } \\
\text { Manufacturing }\end{array}$ & Sustainable Manufacturing & Life Cycle Engineering \\
\hline CSP & Continuous Sampling Plans & Statistical Process Control & $\begin{array}{l}\text { Production Systems and } \\
\text { Organizations }\end{array}$ \\
\hline \multirow[t]{2}{*}{$\mathrm{CT}$} & \multirow[t]{2}{*}{ Computed Tomography } & Automatic X-ray Inspection & Assembly \\
\hline & & Computed Tomography & $\begin{array}{l}\text { Precision Engineering and } \\
\text { Metrology }\end{array}$ \\
\hline \multirow[t]{7}{*}{ CVD } & \multirow[t]{7}{*}{ Chemical Vapor Deposition } & Ultraprecision Grinding & Abrasive Processes \\
\hline & & Ceramic Cutting Tools & Cutting \\
\hline & & Coated Tools & Cutting \\
\hline & & Steel and Stainless Steel & Cutting \\
\hline & & Superhard Tools & Cutting \\
\hline & & $\begin{array}{l}\text { Chemical Vapor Deposition } \\
\text { (CVD) }\end{array}$ & $\begin{array}{l}\text { Electrophysical and Chemical } \\
\text { Processes }\end{array}$ \\
\hline & & Peening & Surfaces \\
\hline CWG & Collaborative Working Group & Learning Factory & $\begin{array}{l}\text { Production Systems and } \\
\text { Organizations }\end{array}$ \\
\hline CWQC & $\begin{array}{l}\text { Company-Wide Quality } \\
\text { Control }\end{array}$ & Quality Assurance & $\begin{array}{l}\text { Precision Engineering and } \\
\text { Metrology }\end{array}$ \\
\hline CYGMA & $\begin{array}{l}\text { Cycle de vie et Gestion des } \\
\text { Métiers et des Applications } \\
\text { (fr); Life Cycle Management } \\
\text { and the Trades and } \\
\text { Applications (en) }\end{array}$ & Knowledge Management & Design \\
\hline DAC & $\begin{array}{l}\text { Design Augmented by } \\
\text { Computer }\end{array}$ & $\begin{array}{l}\text { Computer-Aided } \\
\text { Manufacturing }\end{array}$ & $\begin{array}{l}\text { Production Systems and } \\
\text { Organizations }\end{array}$ \\
\hline
\end{tabular}




\begin{tabular}{|c|c|c|c|}
\hline Abbreviation & Explanation & Term & Section \\
\hline DAE & $\begin{array}{l}\text { Differential and Algebraic } \\
\text { Equation }\end{array}$ & Mechanism & Machines \\
\hline DAI & $\begin{array}{l}\text { Distributed Artificial } \\
\text { Intelligence }\end{array}$ & Artificial Intelligence & $\begin{array}{l}\text { Production Systems and } \\
\text { Organizations }\end{array}$ \\
\hline DAT & Digital Audio Tape & Positioning & $\begin{array}{l}\text { Precision Engineering and } \\
\text { Metrology }\end{array}$ \\
\hline \multirow[t]{3}{*}{$\mathrm{DC}$} & \multirow[t]{3}{*}{ Direct Current } & Electrochemical Grinding & Abrasive Processes \\
\hline & & Coated Tools & Cutting \\
\hline & & $\begin{array}{l}\text { Physical Vapor Deposition } \\
\text { (PVD) }\end{array}$ & $\begin{array}{l}\text { Electrophysical and Chemical } \\
\text { Processes }\end{array}$ \\
\hline DDEs & Delay Differential Equations & Chatter Prediction & Cutting \\
\hline DDE & Delay Differential Equation & Stability & Machines \\
\hline DEA & $\begin{array}{l}\text { Dielectric Elastomer } \\
\text { Actuators }\end{array}$ & Actuator & Machines \\
\hline DED & Directed Energy Deposition & $\begin{array}{l}\text { Additive Manufacturing } \\
\text { Technologies }\end{array}$ & $\begin{array}{l}\text { Electrophysical and Chemical } \\
\text { Processes }\end{array}$ \\
\hline DEDD & $\begin{array}{l}\text { Dry Electro-Discharge- } \\
\text { assisted Dressing }\end{array}$ & Dressing & Abrasive Processes \\
\hline DFA & Design for Assembly & $\begin{array}{l}\text { Cladistics for Products and } \\
\text { Manufacturing }\end{array}$ & $\begin{array}{l}\text { Production Systems and } \\
\text { Organizations }\end{array}$ \\
\hline DfD & Design for Disassembly & EOL Treatment & Life Cycle Engineering \\
\hline DfE & Design for Environment & EOL Treatment & Life Cycle Engineering \\
\hline DfEOL & Design for End-Of-Life & EOL Treatment & Life Cycle Engineering \\
\hline DfLC & Design for Life Cycle & EOL Treatment & Life Cycle Engineering \\
\hline DFMA & $\begin{array}{l}\text { Design for Manufacturability } \\
\text { and Assembly }\end{array}$ & Modular Design & Design \\
\hline DFMC & $\begin{array}{l}\text { Design for Mass } \\
\text { Customization }\end{array}$ & Mass Customization & $\begin{array}{l}\text { Production Systems and } \\
\text { Organizations }\end{array}$ \\
\hline \multirow[t]{2}{*}{ DfR } & \multirow[t]{2}{*}{ Design for Recycling } & EOL Treatment & Life Cycle Engineering \\
\hline & & $\begin{array}{l}\text { Product Life Cycle } \\
\text { Management }\end{array}$ & Life Cycle Engineering \\
\hline DfS & Design for Sustainability & EOL Treatment & Life Cycle Engineering \\
\hline DFT & Design for Test & Electric Test & Assembly \\
\hline DFV & Design for Variety & $\begin{array}{l}\text { Cladistics for Products and } \\
\text { Manufacturing }\end{array}$ & $\begin{array}{l}\text { Production Systems and } \\
\text { Organizations }\end{array}$ \\
\hline DfX & Design for $\mathrm{X}$ & Design Methodology & Design \\
\hline DHM & Digital Human Models & Ergonomic Assessment & Assembly \\
\hline DLP & Digital Light Processing & $\begin{array}{l}\text { Additive Manufacturing } \\
\text { Technologies }\end{array}$ & $\begin{array}{l}\text { Electrophysical and Chemical } \\
\text { Processes }\end{array}$ \\
\hline DLRP & $\begin{array}{l}\text { Distributed Logistics Routing } \\
\text { Protocol }\end{array}$ & $\begin{array}{l}\text { Autonomous Production } \\
\text { Control }\end{array}$ & $\begin{array}{l}\text { Production Systems and } \\
\text { Organizations }\end{array}$ \\
\hline D-MAS & Delegate-Multi-Agent System & $\begin{array}{l}\text { Holonic Manufacturing } \\
\text { Systems }\end{array}$ & $\begin{array}{l}\text { Production Systems and } \\
\text { Organizations }\end{array}$ \\
\hline DMD & Design Matrix Decomposition & Modular Design & Design \\
\hline LMD & Laser Metal Deposition & Rapid Tooling & $\begin{array}{l}\text { Electrophysical and Chemical } \\
\text { Processes }\end{array}$ \\
\hline $\mathrm{DMN}$ & $\begin{array}{l}\text { Dynamic Manufacturing } \\
\text { Network }\end{array}$ & Logistics & $\begin{array}{l}\text { Production Systems and } \\
\text { Organizations }\end{array}$ \\
\hline DMS & $\begin{array}{l}\text { Document Management } \\
\text { Systems }\end{array}$ & Information Management & Design \\
\hline
\end{tabular}




\begin{tabular}{|c|c|c|c|}
\hline Abbreviation & Explanation & Term & Section \\
\hline DMS & $\begin{array}{l}\text { Dedicated Manufacturing } \\
\text { Systems }\end{array}$ & Manufacturing System & $\begin{array}{l}\text { Production Systems and } \\
\text { Organizations }\end{array}$ \\
\hline DMSS & $\begin{array}{l}\text { Decision-Making Support } \\
\text { Systems }\end{array}$ & Decision-Making & Design \\
\hline DMU & Digital Mockup & Assembly Representation & Assembly \\
\hline \multirow[t]{2}{*}{$\mathrm{DNC}$} & \multirow[t]{2}{*}{ Direct Numerical Control } & $\begin{array}{l}\text { Computer-Aided } \\
\text { Manufacturing }\end{array}$ & $\begin{array}{l}\text { Production Systems and } \\
\text { Organizations }\end{array}$ \\
\hline & & $\begin{array}{l}\text { Computer-Integrated } \\
\text { Manufacturing }\end{array}$ & $\begin{array}{l}\text { Production Systems and } \\
\text { Organizations }\end{array}$ \\
\hline DOC & Depth of Cut & High-Speed Cutting & Cutting \\
\hline \multirow[t]{2}{*}{ DOF } & \multirow[t]{2}{*}{ Degree of Freedom } & Chatter Prediction & Cutting \\
\hline & & Mechanism & Machines \\
\hline DP & Dual Property & Cemented Carbides & Cutting \\
\hline DP & Design Parameters & Axiomatic Design & Design \\
\hline $\mathrm{DPF}$ & Diesel Particulate Filters & Microwave Radiation & $\begin{array}{l}\text { Electrophysical and Chemical } \\
\text { Processes }\end{array}$ \\
\hline DPL & Dip Pen Lithography & Nanotechnology & Surfaces \\
\hline DRC & Dual-Resource Constrained & Fuzzy Logic & $\begin{array}{l}\text { Production Systems and } \\
\text { Organizations }\end{array}$ \\
\hline DSFD & Dual-Stage Feed Drives & Actuator & Machines \\
\hline \multirow[t]{2}{*}{ DSM } & \multirow[t]{2}{*}{ Design Structure Matrix } & Design Methodology & Design \\
\hline & & Modular Design & Design \\
\hline DSP & Digital Signal Processor & Magnetic Bearing & Machines \\
\hline DSS & Decision Support Systems & Decision-Making & Design \\
\hline \multirow[t]{2}{*}{ DTM } & \multirow{2}{*}{$\begin{array}{l}\text { Design Theory and } \\
\text { Methodology }\end{array}$} & Design Methodology & Design \\
\hline & & Engineering Design & Design \\
\hline EADS & $\begin{array}{l}\text { European Aeronautic Defence } \\
\text { and Space Company }\end{array}$ & Cold Spray & $\begin{array}{l}\text { Electrophysical and Chemical } \\
\text { Processes }\end{array}$ \\
\hline EAM & Embedded-Atom Method & Molecular Dynamics & Surfaces \\
\hline \multirow[t]{3}{*}{ EBM } & \multirow[t]{3}{*}{ Electron Beam Machining } & Electron Beam Machining & $\begin{array}{l}\text { Electrophysical and Chemical } \\
\text { Processes }\end{array}$ \\
\hline & & Rapid Tooling & $\begin{array}{l}\text { Electrophysical and Chemical } \\
\text { Processes }\end{array}$ \\
\hline & & Specific Energy & $\begin{array}{l}\text { Electrophysical and Chemical } \\
\text { Processes }\end{array}$ \\
\hline EBSD & $\begin{array}{l}\text { Electron Backscatter } \\
\text { Diffraction }\end{array}$ & Surface Integrity & Cutting \\
\hline $\mathrm{EC}$ & Electrochemical & Electrochemical Grinding & Abrasive Processes \\
\hline ECCD & $\begin{array}{l}\text { Electrochemical In-process } \\
\text { Controlled Dressing }\end{array}$ & Electrochemical Dressing & Abrasive Processes \\
\hline ECD & Electrochemical Dressing & Electrochemical Dressing & Abrasive Processes \\
\hline ECDD & $\begin{array}{l}\text { Electro-Contact Discharge } \\
\text { Dressing }\end{array}$ & Dressing & Abrasive Processes \\
\hline ECDM & $\begin{array}{l}\text { Electrochemical Discharge } \\
\text { Machining Dressing }\end{array}$ & Dressing & Abrasive Processes \\
\hline ECG & Electrochemical Grinding & Electrochemical Grinding & Abrasive Processes \\
\hline \multirow[t]{2}{*}{$\mathrm{ECM}$} & \multirow[t]{2}{*}{ Electrochemical Machining } & $\begin{array}{l}\text { Deep Hole Drilling with Small } \\
\text { Diameters }\end{array}$ & Cutting \\
\hline & & Specific Energy & $\begin{array}{l}\text { Electrophysical and Chemical } \\
\text { Processes }\end{array}$ \\
\hline EDD & Electro-Discharge Dressing & Dressing & Abrasive Processes \\
\hline
\end{tabular}




\begin{tabular}{|c|c|c|c|}
\hline Abbreviation & Explanation & Term & Section \\
\hline \multirow[t]{5}{*}{ EDM } & \multirow[t]{5}{*}{$\begin{array}{l}\text { Electrical Discharge } \\
\text { Machining }\end{array}$} & $\begin{array}{l}\text { Deep Hole Drilling with Small } \\
\text { Diameters }\end{array}$ & Cutting \\
\hline & & Electric Discharge Machining & $\begin{array}{l}\text { Electrophysical and Chemical } \\
\text { Processes }\end{array}$ \\
\hline & & Laser Beam Machining & $\begin{array}{l}\text { Electrophysical and Chemical } \\
\text { Processes }\end{array}$ \\
\hline & & Specific Energy & $\begin{array}{l}\text { Electrophysical and Chemical } \\
\text { Processes }\end{array}$ \\
\hline & & Microstructure & Surfaces \\
\hline EDS & $\begin{array}{l}\text { Energy-Dispersive X-ray } \\
\text { Spectroscopy }\end{array}$ & Nanotechnology & Surfaces \\
\hline \multirow[t]{2}{*}{ EDX } & \multirow[t]{2}{*}{ Energy-Dispersive X-ray } & $\begin{array}{l}\text { Machining of Spheroidal } \\
\text { Ductile Iron }\end{array}$ & Cutting \\
\hline & & Surface Integrity & Cutting \\
\hline EER & Energy Efficiency Ratio & $\begin{array}{l}\text { Energy-Efficient } \\
\text { Manufacturing }\end{array}$ & $\begin{array}{l}\text { Production Systems and } \\
\text { Organizations }\end{array}$ \\
\hline EGT & Engineered Grinding Tools & Grinding Tool Structuring & Abrasive Processes \\
\hline EIA & $\begin{array}{l}\text { Electronic Industries } \\
\text { Association }\end{array}$ & $\begin{array}{l}\text { Computer-Aided } \\
\text { Manufacturing }\end{array}$ & $\begin{array}{l}\text { Production Systems and } \\
\text { Organizations }\end{array}$ \\
\hline ELCC & $\begin{array}{l}\text { Environmental Life Cycle } \\
\text { Costing }\end{array}$ & Life Cycle Cost & Life Cycle Engineering \\
\hline ELECTRE & $\begin{array}{l}\text { Elimination et Choix } \\
\text { Traduisant la Réalité (fr) }\end{array}$ & Decision-Making & Design \\
\hline \multirow[t]{6}{*}{ ELID } & \multirow{6}{*}{$\begin{array}{l}\text { Electrolytic In-process } \\
\text { Dressing }\end{array}$} & Dressing & Abrasive Processes \\
\hline & & Electrochemical Dressing & Abrasive Processes \\
\hline & & $\begin{array}{l}\text { Electrolytic In-Process } \\
\text { Dressing }\end{array}$ & Abrasive Processes \\
\hline & & Superabrasives & Abrasive Processes \\
\hline & & Ultraprecision Grinding & Abrasive Processes \\
\hline & & Ultraprecision Machining & Cutting \\
\hline ELV & End-of-Life Vehicles & EOL Treatment & Life Cycle Engineering \\
\hline EMF & Electromagnetic Forming & Mechanical Joining & Forming \\
\hline EMF & Electromotive Force & Sensor (Machines) & Machines \\
\hline EMG & Electromyography & Ergonomic Assessment & Assembly \\
\hline EOSL & End-Of-Service Life & EOL Treatment & Life Cycle Engineering \\
\hline EOU & End-Of-Use & EOL Treatment & Life Cycle Engineering \\
\hline EP & Extreme Pressure & Cutting Fluid & Cutting \\
\hline EPD & $\begin{array}{l}\text { Environmental Product } \\
\text { Declarations }\end{array}$ & Life Cycle Assessment & Life Cycle Engineering \\
\hline ERF & Electro-Rheological Fluids & Actuator & Machines \\
\hline \multirow[t]{7}{*}{ ERP } & \multirow[t]{7}{*}{ Enterprise Resource Planning } & Information Management & Design \\
\hline & & $\begin{array}{l}\text { Computer-Integrated } \\
\text { Manufacturing }\end{array}$ & $\begin{array}{l}\text { Production Systems and } \\
\text { Organizations }\end{array}$ \\
\hline & & $\begin{array}{l}\text { ERP Enterprise Resource } \\
\text { Planning }\end{array}$ & $\begin{array}{l}\text { Production Systems and } \\
\text { Organizations }\end{array}$ \\
\hline & & Operations Management & $\begin{array}{l}\text { Production Systems and } \\
\text { Organizations }\end{array}$ \\
\hline & & Planning & $\begin{array}{l}\text { Production Systems and } \\
\text { Organizations }\end{array}$ \\
\hline & & Production Networks & $\begin{array}{l}\text { Production Systems and } \\
\text { Organizations }\end{array}$ \\
\hline & & Production & $\begin{array}{l}\text { Production Systems and } \\
\text { Organizations }\end{array}$ \\
\hline
\end{tabular}




\begin{tabular}{|c|c|c|c|}
\hline Abbreviation & Explanation & Term & Section \\
\hline ESD & $\begin{array}{l}\text { Entrepreneurial System } \\
\text { Designer }\end{array}$ & Lean Design & Design \\
\hline ESEM & $\begin{array}{l}\text { Environmental Scanning } \\
\text { Electron Microscope }\end{array}$ & $\begin{array}{l}\text { Scanning Electron } \\
\text { Microscope }\end{array}$ & $\begin{array}{l}\text { Precision Engineering and } \\
\text { Metrology }\end{array}$ \\
\hline ET & Eddy Current Testing & Crack Initiation & Surfaces \\
\hline EUSPEN & $\begin{array}{l}\text { European Society for } \\
\text { Precision Engineering and } \\
\text { Nanotechnology }\end{array}$ & Precision & $\begin{array}{l}\text { Precision Engineering and } \\
\text { Metrology }\end{array}$ \\
\hline FACVD & $\begin{array}{l}\text { Flame-Assisted Chemical } \\
\text { Vapor Deposition }\end{array}$ & $\begin{array}{l}\text { Chemical Vapor Deposition } \\
\text { (CVD) }\end{array}$ & $\begin{array}{l}\text { Electrophysical and Chemical } \\
\text { Processes }\end{array}$ \\
\hline FBD & Free-Body Diagrams & Mechanism & Machines \\
\hline FBPSS & $\begin{array}{l}\text { Function Behavior Principle } \\
\text { State Structure }\end{array}$ & Synthesis & Design \\
\hline \multirow[t]{2}{*}{ FBS } & \multirow{2}{*}{$\begin{array}{l}\text { Function Behavior State/ } \\
\text { Structure }\end{array}$} & Function Modeling & Design \\
\hline & & Synthesis & Design \\
\hline FCA & Full-Cost Accounting & Life Cycle Cost & Life Cycle Engineering \\
\hline \multirow[t]{2}{*}{ FCC } & \multirow[t]{2}{*}{ Face-Centered Cubic } & High-Speed Cutting & Cutting \\
\hline & & Molecular Dynamics & Surfaces \\
\hline FCEA & $\begin{array}{l}\text { Full-Cost Environmental } \\
\text { Accounting }\end{array}$ & Life Cycle Cost & Life Cycle Engineering \\
\hline FCP & Full-Cost Pricing & Life Cycle Cost & Life Cycle Engineering \\
\hline FDM & Finite Difference Model & Chatter Prediction & Cutting \\
\hline FDM & Fused Deposition Modeling & $\begin{array}{l}\text { Additive Manufacturing } \\
\text { Technologies }\end{array}$ & $\begin{array}{l}\text { Electrophysical and Chemical } \\
\text { Processes }\end{array}$ \\
\hline \multirow[t]{2}{*}{ FEA } & \multirow[t]{2}{*}{ Finite Element Analysis } & Computer-Aided Design & Design \\
\hline & & Finite Element Analysis & Forming \\
\hline \multirow[t]{12}{*}{ FEM } & \multirow{12}{*}{$\begin{array}{l}\text { Finite Element Method/ } \\
\text { Modeling }\end{array}$} & Chatter Prediction & Cutting \\
\hline & & Coated Tools & Cutting \\
\hline & & Cutting Temperature & Cutting \\
\hline & & Cutting Temperature & Cutting \\
\hline & & $\begin{array}{l}\text { Geometric Modeling of } \\
\text { Machining }\end{array}$ & Cutting \\
\hline & & Modeling in Cutting & Cutting \\
\hline & & Wear Mechanisms & Cutting \\
\hline & & Finite Element Analysis & Forming \\
\hline & & Friction & Forming \\
\hline & & Roll Leveling & Forming \\
\hline & & Vibration & Machines \\
\hline & & Freeform & Surfaces \\
\hline FFT & Fast Fourier Transformation & Monitoring & Cutting \\
\hline \multirow[t]{2}{*}{ FIB } & \multirow[t]{2}{*}{ Focused Ion Beam } & Ultra-Small Micro-End Mills & Cutting \\
\hline & & Ion Beam Machining & $\begin{array}{l}\text { Electrophysical and Chemical } \\
\text { Processes }\end{array}$ \\
\hline FIBID & $\begin{array}{l}\text { Focused Ion Beam-Induced } \\
\text { Deposition }\end{array}$ & Ion Beam Machining & $\begin{array}{l}\text { Electrophysical and Chemical } \\
\text { Processes }\end{array}$ \\
\hline FIFO & First In First Out & $\begin{array}{l}\text { ERP Enterprise Resource } \\
\text { Planning }\end{array}$ & $\begin{array}{l}\text { Production Systems and } \\
\text { Organizations }\end{array}$ \\
\hline FL & Fuzzy Logic & Fuzzy Logic & $\begin{array}{l}\text { Production Systems and } \\
\text { Organizations }\end{array}$ \\
\hline FLC & Forming Limit Curve & Formability (Damage) & Forming \\
\hline FLD & Forming Limit Diagram & Formability (Damage) & Forming \\
\hline
\end{tabular}




\begin{tabular}{|c|c|c|c|}
\hline Abbreviation & Explanation & Term & Section \\
\hline FLM & Fused Layer Modeling & Rapid Tooling & $\begin{array}{l}\text { Electrophysical and Chemical } \\
\text { Processes }\end{array}$ \\
\hline \multirow[t]{4}{*}{ FMEA } & \multirow{4}{*}{$\begin{array}{l}\text { Failure Mode and Effect } \\
\text { Analysis }\end{array}$} & Design Methodology & Design \\
\hline & & Function Modeling & Design \\
\hline & & Cooperative Engineering & $\begin{array}{l}\text { Production Systems and } \\
\text { Organizations }\end{array}$ \\
\hline & & $\begin{array}{l}\text { Industrial Product-Service } \\
\text { System }\end{array}$ & $\begin{array}{l}\text { Production Systems and } \\
\text { Organizations }\end{array}$ \\
\hline \multirow[t]{6}{*}{ FMS } & \multirow[t]{6}{*}{$\begin{array}{l}\text { Flexible Manufacturing } \\
\text { Systems }\end{array}$} & Capacity Planning & $\begin{array}{l}\text { Production Systems and } \\
\text { Organizations }\end{array}$ \\
\hline & & $\begin{array}{l}\text { Computer-Aided } \\
\text { Manufacturing }\end{array}$ & $\begin{array}{l}\text { Production Systems and } \\
\text { Organizations }\end{array}$ \\
\hline & & $\begin{array}{l}\text { Flexible Manufacturing } \\
\text { System }\end{array}$ & $\begin{array}{l}\text { Production Systems and } \\
\text { Organizations }\end{array}$ \\
\hline & & Manufacturing System & $\begin{array}{l}\text { Production Systems and } \\
\text { Organizations }\end{array}$ \\
\hline & & Manufacturing & $\begin{array}{l}\text { Production Systems and } \\
\text { Organizations }\end{array}$ \\
\hline & & Planning & $\begin{array}{l}\text { Production Systems and } \\
\text { Organizations }\end{array}$ \\
\hline FR & Functional Requirements & Axiomatic Design & Design \\
\hline \multirow[t]{2}{*}{ FRF } & \multirow[t]{2}{*}{ Frequency Response Function } & Damping & Machines \\
\hline & & Vibration & Machines \\
\hline FRP & Fiber-Reinforced Plastics & Composite Materials & Cutting \\
\hline FSW & Friction Stir Welding & Welding & Assembly \\
\hline \multirow[t]{2}{*}{ FTS } & \multirow[t]{2}{*}{ Fast Tool Servo } & Diamond Machining & Cutting \\
\hline & & Actuator & Machines \\
\hline FUCE & $\begin{array}{l}\text { Function-Based Cost } \\
\text { Estimating }\end{array}$ & Cost & $\begin{array}{l}\text { Production Systems and } \\
\text { Organizations }\end{array}$ \\
\hline GA & Genetic Algorithm & $\begin{array}{l}\text { Twist Drill Geometry } \\
\text { Optimization }\end{array}$ & Cutting \\
\hline \multirow[t]{3}{*}{ GD\&T } & \multirow[t]{3}{*}{$\begin{array}{l}\text { Geometric Design and } \\
\text { Tolerancing }\end{array}$} & $\begin{array}{l}\text { Tolerancing (Kinematic } \\
\text { Approach to) }\end{array}$ & Design \\
\hline & & Tolerancing & Design \\
\hline & & $\begin{array}{l}\text { Geometrical Product } \\
\text { Specification }\end{array}$ & $\begin{array}{l}\text { Precision Engineering and } \\
\text { Metrology }\end{array}$ \\
\hline GDM & Gross Domestic Product & Smart Products & Design \\
\hline GDT & General Design Theory & Design Methodology & Design \\
\hline GE & General Electric & Superabrasives & Abrasive Processes \\
\hline GKS & Graphic Kernel System & $\begin{array}{l}\text { Computer-Aided } \\
\text { Manufacturing }\end{array}$ & $\begin{array}{l}\text { Production Systems and } \\
\text { Organizations }\end{array}$ \\
\hline GLARE & $\begin{array}{l}\text { Glass Laminate Aluminum- } \\
\text { Reinforced Epoxy }\end{array}$ & $\begin{array}{l}\text { Machinability of Carbon } \\
\text { Fiber-Reinforced and GLARE }\end{array}$ & Cutting \\
\hline GM & General Motors & $\begin{array}{l}\text { Computer-Aided } \\
\text { Manufacturing }\end{array}$ & $\begin{array}{l}\text { Production Systems and } \\
\text { Organizations }\end{array}$ \\
\hline \multirow[t]{2}{*}{ GPS } & \multirow{2}{*}{$\begin{array}{l}\text { Geometrical Product } \\
\text { Specification }\end{array}$} & Tolerancing & Design \\
\hline & & $\begin{array}{l}\text { Geometrical Product } \\
\text { Specification }\end{array}$ & $\begin{array}{l}\text { Precision Engineering and } \\
\text { Metrology }\end{array}$ \\
\hline GPS & Global Positioning System & Precision Positioning & $\begin{array}{l}\text { Precision Engineering and } \\
\text { Metrology }\end{array}$ \\
\hline
\end{tabular}




\begin{tabular}{|c|c|c|c|}
\hline Abbreviation & Explanation & Term & Section \\
\hline \multirow[t]{3}{*}{ GUM } & \multirow{3}{*}{$\begin{array}{l}\text { Guide to the expression of } \\
\text { Uncertainty in Measurement }\end{array}$} & Tolerancing & Design \\
\hline & & Error & $\begin{array}{l}\text { Precision Engineering and } \\
\text { Metrology }\end{array}$ \\
\hline & & Reversal & $\begin{array}{l}\text { Precision Engineering and } \\
\text { Metrology }\end{array}$ \\
\hline \multirow[t]{2}{*}{ HAZ } & \multirow[t]{2}{*}{ Heat-Affected Zone } & Laser Welding & Assembly \\
\hline & & Cold Spray & $\begin{array}{l}\text { Electrophysical and Chemical } \\
\text { Processes }\end{array}$ \\
\hline HCA & Human-Centered Automation & Human-Centered Automation & Assembly \\
\hline $\mathrm{HCP}$ & Hexagonal Close-Packed & Deformation (Dislocations) & Forming \\
\hline HDD & $\begin{array}{l}\text { Hydromechanical Deep } \\
\text { Drawing }\end{array}$ & $\begin{array}{l}\text { Hydroforming (Sheets and } \\
\text { Tubes) }\end{array}$ & Forming \\
\hline HDMI & $\begin{array}{l}\text { High-Definition Multimedia } \\
\text { Interface }\end{array}$ & Product Architecture & Design \\
\hline \multirow[t]{3}{*}{ HEDG } & \multirow[t]{3}{*}{$\begin{array}{l}\text { High-Efficiency Deep } \\
\text { Grinding }\end{array}$} & $\begin{array}{l}\text { High-Performance Dry } \\
\text { Grinding }\end{array}$ & Abrasive Processes \\
\hline & & High-Performance Grinding & Abrasive Processes \\
\hline & & Superabrasives & Abrasive Processes \\
\hline HEG & High-Efficiency Grinding & $\begin{array}{l}\text { High-Performance Dry } \\
\text { Grinding }\end{array}$ & Abrasive Processes \\
\hline HIG & High Isostatic Gas pressure & Cemented Carbides & Cutting \\
\hline HIP & Hot Isostatic Pressing & Ceramic Cutting Tools & Cutting \\
\hline HIP & High Ionization Pulsing & $\begin{array}{l}\text { Physical Vapor Deposition } \\
\text { (PVD) }\end{array}$ & $\begin{array}{l}\text { Electrophysical and Chemical } \\
\text { Processes }\end{array}$ \\
\hline \multirow[t]{2}{*}{ HIPIMS } & \multirow[t]{2}{*}{$\begin{array}{l}\text { High-Power Impulse } \\
\text { Magnetron Sputtering }\end{array}$} & $\begin{array}{l}\text { Physical Vapor Deposition } \\
\text { (PVD) }\end{array}$ & $\begin{array}{l}\text { Electrophysical and Chemical } \\
\text { Processes }\end{array}$ \\
\hline & & Sputtering & $\begin{array}{l}\text { Electrophysical and Chemical } \\
\text { Processes }\end{array}$ \\
\hline HMD & Head-Mounted Display & Augmented Reality & Design \\
\hline HMES & $\begin{array}{l}\text { Holonic Manufacturing } \\
\text { Execution System }\end{array}$ & $\begin{array}{l}\text { Holonic Manufacturing } \\
\text { Systems }\end{array}$ & $\begin{array}{l}\text { Production Systems and } \\
\text { Organizations }\end{array}$ \\
\hline \multirow[t]{2}{*}{ HMS } & \multirow[t]{2}{*}{$\begin{array}{l}\text { Holonic Manufacturing } \\
\text { Systems }\end{array}$} & Cyber-Physical Systems & $\begin{array}{l}\text { Production Systems and } \\
\text { Organizations }\end{array}$ \\
\hline & & $\begin{array}{l}\text { Holonic Manufacturing } \\
\text { Systems }\end{array}$ & $\begin{array}{l}\text { Production Systems and } \\
\text { Organizations }\end{array}$ \\
\hline HNS & High Nitrogen Steels & Bearing & Machines \\
\hline \multirow[t]{3}{*}{$\mathrm{HPC}$} & \multirow[t]{3}{*}{ High-Performance Cutting } & Coated Tools & Cutting \\
\hline & & High-Speed Cutting & Cutting \\
\hline & & Spindle & Machines \\
\hline HPD & Hardness Penetration Depth & Grind-Hardening & Abrasive Processes \\
\hline HPDG & $\begin{array}{l}\text { High-Performance Dry } \\
\text { Grinding }\end{array}$ & $\begin{array}{l}\text { High-Performance Dry } \\
\text { Grinding }\end{array}$ & Abrasive Processes \\
\hline HPDL & High-Power Diode Laser & Laser Welding & Assembly \\
\hline HPG & High-Performance Grinding & High-Performance Grinding & Abrasive Processes \\
\hline HPPMS & $\begin{array}{l}\text { High-Power Pulsed } \\
\text { Magnetron Sputtering }\end{array}$ & $\begin{array}{l}\text { Physical Vapor Deposition } \\
\text { (PVD) }\end{array}$ & $\begin{array}{l}\text { Electrophysical and Chemical } \\
\text { Processes }\end{array}$ \\
\hline \multirow[t]{3}{*}{$\mathrm{HSC}$} & \multirow[t]{3}{*}{ High-Speed Cutting } & Coated Tools & Cutting \\
\hline & & High-Speed Cutting & Cutting \\
\hline & & Spindle & Machines \\
\hline HSIC & High-Speed Impact Cutting & Billet Shearing & Forming \\
\hline HSK & Hollow Taper Shank & Tool Holder & Cutting \\
\hline
\end{tabular}




\begin{tabular}{|c|c|c|c|}
\hline Abbreviation & Explanation & Term & Section \\
\hline HSM & High-Speed Machining & High-Speed Cutting & Cutting \\
\hline \multirow[t]{5}{*}{ HSS } & \multirow[t]{5}{*}{ High-Speed Steel } & Abrasive Material & Abrasive Processes \\
\hline & & Broaching & Cutting \\
\hline & & Cemented Carbides & Cutting \\
\hline & & Cermets & Cutting \\
\hline & & Machinability of Carbon Steel & Cutting \\
\hline HVOF & High-Velocity Oxygen Fuel & Cold Spray & $\begin{array}{l}\text { Electrophysical and Chemical } \\
\text { Processes }\end{array}$ \\
\hline IAD & Intelligent Assist Devices & $\begin{array}{l}\text { Human-Machine } \\
\text { Collaboration }\end{array}$ & Assembly \\
\hline IBC & Isolated Boundary Condition & Molecular Dynamics & Surfaces \\
\hline IBF & Ion Beam Figuring & Ion Beam Machining & $\begin{array}{l}\text { Electrophysical and Chemical } \\
\text { Processes }\end{array}$ \\
\hline IBIS & $\begin{array}{l}\text { Issue-Based Information } \\
\text { System }\end{array}$ & Decision-Making & Design \\
\hline IBM & Ion Beam Machining & Ion Beam Machining & $\begin{array}{l}\text { Electrophysical and Chemical } \\
\text { Processes }\end{array}$ \\
\hline \multirow[t]{2}{*}{ IC } & \multirow[t]{2}{*}{ Integrated Circuits } & Optical Inspection & Assembly \\
\hline & & Wire Bonding & Assembly \\
\hline ICFG & $\begin{array}{l}\text { International Cold Forging } \\
\text { Group }\end{array}$ & Cold Forging & Forming \\
\hline \multirow[t]{8}{*}{ ICT } & \multirow[t]{8}{*}{$\begin{array}{l}\text { Information and } \\
\text { Communications Technology }\end{array}$} & Factory & $\begin{array}{l}\text { Production Systems and } \\
\text { Organizations }\end{array}$ \\
\hline & & Knowledge-Based System & $\begin{array}{l}\text { Production Systems and } \\
\text { Organizations }\end{array}$ \\
\hline & & Manufacturing System & $\begin{array}{l}\text { Production Systems and } \\
\text { Organizations }\end{array}$ \\
\hline & & Manufacturing & $\begin{array}{l}\text { Production Systems and } \\
\text { Organizations }\end{array}$ \\
\hline & & Mass Customization & $\begin{array}{l}\text { Production Systems and } \\
\text { Organizations }\end{array}$ \\
\hline & & Production Networks & $\begin{array}{l}\text { Production Systems and } \\
\text { Organizations }\end{array}$ \\
\hline & & Production & $\begin{array}{l}\text { Production Systems and } \\
\text { Organizations }\end{array}$ \\
\hline & & $\begin{array}{l}\text { Virtual Reality in } \\
\text { Manufacturing }\end{array}$ & $\begin{array}{l}\text { Production Systems and } \\
\text { Organizations }\end{array}$ \\
\hline IGBT & $\begin{array}{l}\text { Insulated-Gate Bipolar } \\
\text { Transistor }\end{array}$ & Wire Bonding & Assembly \\
\hline IGES & $\begin{array}{l}\text { Initial Graphics Exchange } \\
\text { Specification }\end{array}$ & Computer-Aided Design & Design \\
\hline IM & Information Management & Information Management & Design \\
\hline IMP & Intermetallic Phases & Diffusion Soldering & Abrasive Processes \\
\hline IMPACT & $\begin{array}{l}\text { Intelligent Manufacturing } \\
\text { Planning and Control }\end{array}$ & Production & $\begin{array}{l}\text { Production Systems and } \\
\text { Organizations }\end{array}$ \\
\hline \multirow[t]{2}{*}{ IMS } & \multirow[t]{2}{*}{$\begin{array}{l}\text { Intelligent Manufacturing } \\
\text { Systems }\end{array}$} & Artificial Intelligence & $\begin{array}{l}\text { Production Systems and } \\
\text { Organizations }\end{array}$ \\
\hline & & Cyber-Physical Systems & $\begin{array}{l}\text { Production Systems and } \\
\text { Organizations }\end{array}$ \\
\hline INCOSE & $\begin{array}{l}\text { International Council of } \\
\text { System Engineering }\end{array}$ & Smart Products & Design \\
\hline IoD & Internet of Data & Smart Products & Design \\
\hline
\end{tabular}




\begin{tabular}{|c|c|c|c|}
\hline Abbreviation & Explanation & Term & Section \\
\hline $\mathrm{IoH}$ & Internet of Humans & Smart Products & Design \\
\hline IoS & Internet of Services & Smart Products & Design \\
\hline \multirow[t]{2}{*}{ IoT } & \multirow[t]{2}{*}{ Internet of Things } & Smart Products & Design \\
\hline & & Production Networks & $\begin{array}{l}\text { Production Systems and } \\
\text { Organizations }\end{array}$ \\
\hline IP & Integer Programming & $\begin{array}{l}\text { Optimization in } \\
\text { Manufacturing }\end{array}$ & $\begin{array}{l}\text { Production Systems and } \\
\text { Organizations }\end{array}$ \\
\hline IPSS & $\begin{array}{l}\text { Industrial Product-Service } \\
\text { System }\end{array}$ & $\begin{array}{l}\text { Industrial Product-Service } \\
\text { System }\end{array}$ & $\begin{array}{l}\text { Production Systems and } \\
\text { Organizations }\end{array}$ \\
\hline IRDAC & $\begin{array}{l}\text { Industrial Research and } \\
\text { Development Advisory } \\
\text { Committee }\end{array}$ & Mechatronics & Machines \\
\hline \multirow[t]{2}{*}{ IS } & \multirow[t]{2}{*}{ Information Systems } & Information Management & Design \\
\hline & & Knowledge Management & Design \\
\hline \multirow[t]{2}{*}{ ISO } & \multirow{2}{*}{$\begin{array}{l}\text { International Organization for } \\
\text { Standardization }\end{array}$} & Life Cycle Assessment & Life Cycle Engineering \\
\hline & & $\begin{array}{l}\text { Geometrical Product } \\
\text { Specification }\end{array}$ & $\begin{array}{l}\text { Precision Engineering and } \\
\text { Metrology }\end{array}$ \\
\hline IT & Information Technology & Information Management & Design \\
\hline \multirow[t]{4}{*}{ JIT } & \multirow[t]{4}{*}{ Just-In-Time } & Lean Production & $\begin{array}{l}\text { Production Systems and } \\
\text { Organizations }\end{array}$ \\
\hline & & Manufacturing System & $\begin{array}{l}\text { Production Systems and } \\
\text { Organizations }\end{array}$ \\
\hline & & Manufacturing & $\begin{array}{l}\text { Production Systems and } \\
\text { Organizations }\end{array}$ \\
\hline & & Production Planning & $\begin{array}{l}\text { Production Systems and } \\
\text { Organizations }\end{array}$ \\
\hline JIT-DM & $\begin{array}{l}\text { Just-In-Time Decision- } \\
\text { Making }\end{array}$ & Lean Design & Design \\
\hline JSPE & $\begin{array}{l}\text { Japan Society for Precision } \\
\text { Engineering }\end{array}$ & Precision & $\begin{array}{l}\text { Precision Engineering and } \\
\text { Metrology }\end{array}$ \\
\hline KADS & $\begin{array}{l}\text { Knowledge Acquisition and } \\
\text { Documentation System }\end{array}$ & Knowledge Management & Design \\
\hline KBE & $\begin{array}{l}\text { Knowledge-Based } \\
\text { Environments }\end{array}$ & Knowledge Management & Design \\
\hline \multirow[t]{2}{*}{ KBS } & \multirow[t]{2}{*}{ Knowledge-Based Systems } & Knowledge Management & Design \\
\hline & & Knowledge-Based System & $\begin{array}{l}\text { Production Systems and } \\
\text { Organizations }\end{array}$ \\
\hline KDD & $\begin{array}{l}\text { Knowledge Discovery in } \\
\text { Databases }\end{array}$ & Neural Network & $\begin{array}{l}\text { Production Systems and } \\
\text { Organizations }\end{array}$ \\
\hline KISF & $\begin{array}{l}\text { Kinematic Incremental Sheet } \\
\text { Forming }\end{array}$ & Incremental Forming & Forming \\
\hline \multirow[t]{2}{*}{ KM } & \multirow[t]{2}{*}{ Knowledge Management } & Information Management & Design \\
\hline & & Knowledge Management & Design \\
\hline LAN & Local Area Network & $\begin{array}{l}\text { Flexible Manufacturing } \\
\text { System }\end{array}$ & $\begin{array}{l}\text { Production Systems and } \\
\text { Organizations }\end{array}$ \\
\hline LBM & Laser Beam Machining & Specific Energy & $\begin{array}{l}\text { Electrophysical and Chemical } \\
\text { Processes }\end{array}$ \\
\hline LBW & Laser Beam Welding & Laser Welding & Assembly \\
\hline \multirow[t]{4}{*}{ LCA } & \multirow{4}{*}{$\begin{array}{l}\text { Life Cycle Assessment/ } \\
\text { Accounting }\end{array}$} & Life Cycle Assessment & Life Cycle Engineering \\
\hline & & $\begin{array}{l}\text { Life Cycle Assessment: Goal } \\
\text { and Scope Definition }\end{array}$ & Life Cycle Engineering \\
\hline & & Life Cycle Cost & Life Cycle Engineering \\
\hline & & Life Cycle Impact Assessment & Life Cycle Engineering \\
\hline
\end{tabular}




\begin{tabular}{|c|c|c|c|}
\hline Abbreviation & Explanation & Term & Section \\
\hline \multirow[t]{2}{*}{$\mathrm{LCC}$} & \multirow[t]{2}{*}{ Life Cycle Costing } & Life Cycle Cost & Life Cycle Engineering \\
\hline & & Life Cycle Cost & Life Cycle Engineering \\
\hline LCCA & Life Cycle Cost Assessment & Life Cycle Cost & Life Cycle Engineering \\
\hline LCE & Life Cycle Engineering & Life Cycle Engineering & Life Cycle Engineering \\
\hline LCI & Life Cycle Inventory & Life Cycle Assessment & Life Cycle Engineering \\
\hline \multirow[t]{3}{*}{ LCIA } & \multirow[t]{3}{*}{ Life Cycle Impact Assessment } & Environmental Impact & Life Cycle Engineering \\
\hline & & Life Cycle Assessment & Life Cycle Engineering \\
\hline & & Life Cycle Impact Assessment & Life Cycle Engineering \\
\hline LCL & Lower Control Limit & Statistical Process Control & $\begin{array}{l}\text { Production Systems and } \\
\text { Organizations }\end{array}$ \\
\hline LCS & Local Coordinate System & $\begin{array}{l}\text { Five-Axis Tool Path } \\
\text { Generation }\end{array}$ & Cutting \\
\hline LCSA & $\begin{array}{l}\text { Life Cycle Sustainability } \\
\text { Assessment }\end{array}$ & Life Cycle Assessment & Life Cycle Engineering \\
\hline LDR & Limiting Drawing Ratios & $\begin{array}{l}\text { Hydroforming (Sheets and } \\
\text { Tubes) }\end{array}$ & Forming \\
\hline LED & Light-Emitting Diode & Sensor Assembly & Assembly \\
\hline LENS & $\begin{array}{l}\text { Laser-Engineered Net } \\
\text { Shaping }\end{array}$ & Specific Energy & $\begin{array}{l}\text { Electrophysical and Chemical } \\
\text { Processes }\end{array}$ \\
\hline LFVAD & $\begin{array}{l}\text { Low-Frequency Vibration- } \\
\text { Assisted Drilling }\end{array}$ & Materials & Cutting \\
\hline LFW & Linear Friction Welding & Welding & Assembly \\
\hline LIDT & $\begin{array}{l}\text { Laser-Induced Damage } \\
\text { Threshold }\end{array}$ & Crack Initiation & Surfaces \\
\hline LLM & $\begin{array}{l}\text { Layer Laminate } \\
\text { Manufacturing }\end{array}$ & Rapid Tooling & $\begin{array}{l}\text { Electrophysical and Chemical } \\
\text { Processes }\end{array}$ \\
\hline LMIS & Liquid-Metal Ion Sources & Ion Beam Machining & $\begin{array}{l}\text { Electrophysical and Chemical } \\
\text { Processes }\end{array}$ \\
\hline LMS & $\begin{array}{l}\text { Manufacturing Systems and } \\
\text { Automation }\end{array}$ & Cost & $\begin{array}{l}\text { Production Systems and } \\
\text { Organizations }\end{array}$ \\
\hline LoA & Level of Automation & Human-Centered Automation & Assembly \\
\hline LOC & Logistic Operating Curves & Logistic Curves & $\begin{array}{l}\text { Production Systems and } \\
\text { Organizations }\end{array}$ \\
\hline LODTM & $\begin{array}{l}\text { Large Optics Diamond } \\
\text { Turning Machine }\end{array}$ & Ultraprecision & Machines \\
\hline \multirow[t]{2}{*}{ LOM } & \multirow[t]{2}{*}{$\begin{array}{l}\text { Laminated Object } \\
\text { Manufacturing }\end{array}$} & $\begin{array}{l}\text { Additive Manufacturing } \\
\text { Technologies }\end{array}$ & $\begin{array}{l}\text { Electrophysical and Chemical } \\
\text { Processes }\end{array}$ \\
\hline & & Specific Energy & $\begin{array}{l}\text { Electrophysical and Chemical } \\
\text { Processes }\end{array}$ \\
\hline LPD & Lean Product Development & Lean Design & Design \\
\hline LPP & Linear Pallet Pools & Machine Tool & Machines \\
\hline LSL & Lower Specification Limit & Statistical Process Control & $\begin{array}{l}\text { Production Systems and } \\
\text { Organizations }\end{array}$ \\
\hline LSPL & $\begin{array}{l}\text { Least-Squares Reference } \\
\text { Plane }\end{array}$ & Flatness & $\begin{array}{l}\text { Precision Engineering and } \\
\text { Metrology }\end{array}$ \\
\hline MAC & Modal Assurance Criterion & Structural Analysis & Machines \\
\hline MADM & $\begin{array}{l}\text { Multiple-Attribute Decision- } \\
\text { Making }\end{array}$ & Decision-Making & Design \\
\hline MAF & Magnetic Abrasive Finishing & Finishing & Abrasive Processes \\
\hline MAG & Metal Active Gas & Welding & Assembly \\
\hline MAI & Multiple Angle of Incidence & Ellipsometry & Surfaces \\
\hline
\end{tabular}




\begin{tabular}{|c|c|c|c|}
\hline Abbreviation & Explanation & Term & Section \\
\hline \multirow[t]{2}{*}{ MAS } & \multirow[t]{2}{*}{ Multi-Agent System } & Artificial Intelligence & $\begin{array}{l}\text { Production Systems and } \\
\text { Organizations }\end{array}$ \\
\hline & & Cyber-Physical Systems & $\begin{array}{l}\text { Production Systems and } \\
\text { Organizations }\end{array}$ \\
\hline MASK & $\begin{array}{l}\text { Method for Analyzing and } \\
\text { Structuring Knowledge }\end{array}$ & Knowledge Management & Design \\
\hline MBE & Molecular Beam Epitaxy & Nanotechnology & Surfaces \\
\hline MCDM & $\begin{array}{l}\text { Multiple-Criteria Decision- } \\
\text { Making }\end{array}$ & Decision-Making & Design \\
\hline \multirow[t]{2}{*}{ MD } & \multirow[t]{2}{*}{ Molecular Dynamics } & $\begin{array}{l}\text { Molecular Dynamics for } \\
\text { Cutting Processes }\end{array}$ & Cutting \\
\hline & & Molecular Dynamics & Surfaces \\
\hline \multirow[t]{2}{*}{ MDOF } & \multirow[t]{2}{*}{ Multiple Degree of Freedom } & Chatter Prediction & Cutting \\
\hline & & Precision Positioning & $\begin{array}{l}\text { Precision Engineering and } \\
\text { Metrology }\end{array}$ \\
\hline MDP & Markov Decision Process & Neural Network & $\begin{array}{l}\text { Production Systems and } \\
\text { Organizations }\end{array}$ \\
\hline \multirow[t]{2}{*}{ MEMS } & \multirow{2}{*}{$\begin{array}{l}\text { Microelectromechanical } \\
\text { Systems }\end{array}$} & Sensor Assembly & Assembly \\
\hline & & Electroforming & $\begin{array}{l}\text { Electrophysical and Chemical } \\
\text { Processes }\end{array}$ \\
\hline MFD & $\begin{array}{l}\text { Modular Function } \\
\text { Deployment }\end{array}$ & Modular Design & Design \\
\hline MHIA & $\begin{array}{l}\text { Material Handling Industry of } \\
\text { America }\end{array}$ & Handling & Assembly \\
\hline \multirow[t]{2}{*}{ MHS } & \multirow[t]{2}{*}{ Material Handling Systems } & Complexity in Manufacturing & $\begin{array}{l}\text { Production Systems and } \\
\text { Organizations }\end{array}$ \\
\hline & & Manufacturing System & $\begin{array}{l}\text { Production Systems and } \\
\text { Organizations }\end{array}$ \\
\hline MIG & Metal Inert Gas & Welding & Assembly \\
\hline \multirow[t]{2}{*}{ MILP } & \multirow[t]{2}{*}{$\begin{array}{l}\text { Mixed-Integer Linear } \\
\text { Programming }\end{array}$} & $\begin{array}{l}\text { Optimization in } \\
\text { Manufacturing }\end{array}$ & $\begin{array}{l}\text { Production Systems and } \\
\text { Organizations }\end{array}$ \\
\hline & & Scheduling & $\begin{array}{l}\text { Production Systems and } \\
\text { Organizations }\end{array}$ \\
\hline MJ & Material Jetting & $\begin{array}{l}\text { Additive Manufacturing } \\
\text { Technologies }\end{array}$ & $\begin{array}{l}\text { Electrophysical and Chemical } \\
\text { Processes }\end{array}$ \\
\hline MJM & Multi-Jet Modeling & Rapid Tooling & $\begin{array}{l}\text { Electrophysical and Chemical } \\
\text { Processes }\end{array}$ \\
\hline MKMS & $\begin{array}{l}\text { Methodology for Knowledge } \\
\text { Management System }\end{array}$ & Knowledge Management & Design \\
\hline \multirow[t]{2}{*}{ ML } & \multirow[t]{2}{*}{ Machine Learning } & Artificial Intelligence & $\begin{array}{l}\text { Production Systems and } \\
\text { Organizations }\end{array}$ \\
\hline & & Cyber-Physical Systems & $\begin{array}{l}\text { Production Systems and } \\
\text { Organizations }\end{array}$ \\
\hline MLP & Multilayer Perceptron & Neural Network & $\begin{array}{l}\text { Production Systems and } \\
\text { Organizations }\end{array}$ \\
\hline MMC & Metal Matrix Composites & Composite Materials & Cutting \\
\hline MOCVD & $\begin{array}{l}\text { Metal-Organic Chemical } \\
\text { Vapor Deposition }\end{array}$ & $\begin{array}{l}\text { Chemical Vapor Deposition } \\
\text { (CVD) }\end{array}$ & $\begin{array}{l}\text { Electrophysical and Chemical } \\
\text { Processes }\end{array}$ \\
\hline MODM & $\begin{array}{l}\text { Multiple-Objective Decision- } \\
\text { Making }\end{array}$ & Decision-Making & Design \\
\hline MOGeP & $\begin{array}{l}\text { Multi-Objective Geometric } \\
\text { Programming }\end{array}$ & Decision-Making & Design \\
\hline
\end{tabular}




\begin{tabular}{|c|c|c|c|}
\hline Abbreviation & Explanation & Term & Section \\
\hline MOGoP & $\begin{array}{l}\text { Multi-Objective Goal } \\
\text { Programming }\end{array}$ & Decision-Making & Design \\
\hline MOKA & $\begin{array}{l}\text { Methodology and Tools } \\
\text { Oriented to Knowledge } \\
\text { Engineering Applications }\end{array}$ & Knowledge Management & Design \\
\hline MOLP & $\begin{array}{l}\text { Multi-Objective Linear } \\
\text { Programming }\end{array}$ & Decision-Making & Design \\
\hline MOM & Middle of Maximum & Fuzzy Logic & $\begin{array}{l}\text { Production Systems and } \\
\text { Organizations }\end{array}$ \\
\hline \multirow[t]{2}{*}{ MPE } & \multirow[t]{2}{*}{ Maximum Permissible Error } & Machine & $\begin{array}{l}\text { Precision Engineering and } \\
\text { Metrology }\end{array}$ \\
\hline & & Error & $\begin{array}{l}\text { Precision Engineering and } \\
\text { Metrology }\end{array}$ \\
\hline \multirow[t]{7}{*}{ MQL } & \multirow{7}{*}{$\begin{array}{l}\text { Minimum Quantity } \\
\text { Lubrication }\end{array}$} & Nozzle Design & Abrasive Processes \\
\hline & & Cutting Fluid & Cutting \\
\hline & & High-Speed Cutting & Cutting \\
\hline & & Machinability of Carbon Steel & Cutting \\
\hline & & $\begin{array}{l}\text { Molecular Dynamics for } \\
\text { Cutting Processes }\end{array}$ & Cutting \\
\hline & & Sustainability of Machining & Cutting \\
\hline & & Spindle & Machines \\
\hline MR & Mixed Reality & Augmented Reality & Design \\
\hline MRF & Magneto-Rheological Fluids & Actuator & Machines \\
\hline \multirow[t]{3}{*}{ MRP } & \multirow[t]{3}{*}{$\begin{array}{l}\text { Material Requirements } \\
\text { Planning }\end{array}$} & $\begin{array}{l}\text { ERP Enterprise Resource } \\
\text { Planning }\end{array}$ & $\begin{array}{l}\text { Production Systems and } \\
\text { Organizations }\end{array}$ \\
\hline & & Operations Management & $\begin{array}{l}\text { Production Systems and } \\
\text { Organizations }\end{array}$ \\
\hline & & Planning & $\begin{array}{l}\text { Production Systems and } \\
\text { Organizations }\end{array}$ \\
\hline MRPI & $\begin{array}{l}\text { Material Requirements } \\
\text { Planning }\end{array}$ & Information Management & Design \\
\hline \multirow[t]{2}{*}{ MRPII } & \multirow{2}{*}{$\begin{array}{l}\text { Manufacturing Resource } \\
\text { Planning }\end{array}$} & Information Management & Design \\
\hline & & Operations Management & $\begin{array}{l}\text { Production Systems and } \\
\text { Organizations }\end{array}$ \\
\hline \multirow[t]{2}{*}{ MRR } & \multirow[t]{2}{*}{ Material Removal Rates } & High-Performance Grinding & Abrasive Processes \\
\hline & & Self-Propelled Rotary Tool & Cutting \\
\hline MS & Manufacturing System & $\begin{array}{l}\text { Holonic Manufacturing } \\
\text { Systems }\end{array}$ & $\begin{array}{l}\text { Production Systems and } \\
\text { Organizations }\end{array}$ \\
\hline MSM & Magnetic Shape Memory & Actuator & Machines \\
\hline MST & $\begin{array}{l}\text { Manufacturing Science and } \\
\text { Technology }\end{array}$ & Manufacturing System & $\begin{array}{l}\text { Production Systems and } \\
\text { Organizations }\end{array}$ \\
\hline MT & Magnetic Particle Testing & Crack Initiation & Surfaces \\
\hline MTBF & Mean Time Between Failures & Assembly Line & Assembly \\
\hline MTF & $\begin{array}{l}\text { Modulation Transfer } \\
\text { Functions }\end{array}$ & Resolution & $\begin{array}{l}\text { Precision Engineering and } \\
\text { Metrology }\end{array}$ \\
\hline MZPL & Minimum-Zone Plane & Flatness & $\begin{array}{l}\text { Precision Engineering and } \\
\text { Metrology }\end{array}$ \\
\hline NACFAM & $\begin{array}{l}\text { National Council for } \\
\text { Advanced Manufacturing }\end{array}$ & Sustainable Manufacturing & Life Cycle Engineering \\
\hline NAPLPS & $\begin{array}{l}\text { North American Presentation } \\
\text { Level Protocol Syntax }\end{array}$ & $\begin{array}{l}\text { Computer-Aided } \\
\text { Manufacturing }\end{array}$ & $\begin{array}{l}\text { Production Systems and } \\
\text { Organizations }\end{array}$ \\
\hline
\end{tabular}




\begin{tabular}{|c|c|c|c|}
\hline Abbreviation & Explanation & Term & Section \\
\hline \multirow[t]{8}{*}{$\mathrm{NC}$} & \multirow[t]{8}{*}{ Numerical Control } & Burr & Cutting \\
\hline & & $\begin{array}{l}\text { Five-Axis Tool Path } \\
\text { Generation }\end{array}$ & Cutting \\
\hline & & Adaptive Control & Machines \\
\hline & & Computer Numerical Control & Machines \\
\hline & & Open Architecture & Machines \\
\hline & & Precision Positioning & $\begin{array}{l}\text { Precision Engineering and } \\
\text { Metrology }\end{array}$ \\
\hline & & $\begin{array}{l}\text { Computer-Aided } \\
\text { Manufacturing }\end{array}$ & $\begin{array}{l}\text { Production Systems and } \\
\text { Organizations }\end{array}$ \\
\hline & & $\begin{array}{l}\text { Computer-Integrated } \\
\text { Manufacturing }\end{array}$ & $\begin{array}{l}\text { Production Systems and } \\
\text { Organizations }\end{array}$ \\
\hline NGO & $\begin{array}{l}\text { Nongovernmental } \\
\text { Organization }\end{array}$ & $\begin{array}{l}\text { Management of Production } \\
\text { Enterprises }\end{array}$ & $\begin{array}{l}\text { Production Systems and } \\
\text { Organizations }\end{array}$ \\
\hline NIST & $\begin{array}{l}\text { National Institute of Standards } \\
\text { and Technology }\end{array}$ & Traceability & $\begin{array}{l}\text { Precision Engineering and } \\
\text { Metrology }\end{array}$ \\
\hline NITAL & Nitric Acid and Alcohol & Grinding Burn & Abrasive Processes \\
\hline \multirow[t]{2}{*}{ NMI } & \multirow[t]{2}{*}{ National Metrology Institutes } & Precision Positioning & $\begin{array}{l}\text { Precision Engineering and } \\
\text { Metrology }\end{array}$ \\
\hline & & Traceability & $\begin{array}{l}\text { Precision Engineering and } \\
\text { Metrology }\end{array}$ \\
\hline $\mathrm{NN}$ & Neural Networks & Fuzzy Logic & $\begin{array}{l}\text { Production Systems and } \\
\text { Organizations }\end{array}$ \\
\hline NNA & Neural Network Approach & Modeling of Face Milling & Cutting \\
\hline \multirow[t]{2}{*}{ NURBS } & \multirow[t]{2}{*}{$\begin{array}{l}\text { Nonuniform Rational } \\
\text { B-Spline }\end{array}$} & $\begin{array}{l}\text { Five-Axis Tool Path } \\
\text { Generation }\end{array}$ & Cutting \\
\hline & & Freeform & Surfaces \\
\hline ODE & $\begin{array}{l}\text { Ordinary Differential } \\
\text { Equations }\end{array}$ & Chatter Prediction & Cutting \\
\hline \multirow[t]{5}{*}{ OEM } & \multirow{5}{*}{$\begin{array}{l}\text { Original Equipment } \\
\text { Manufacturers }\end{array}$} & Biomimetic Design & Design \\
\hline & & Hot Stamping & Forming \\
\hline & & Disassembly & Life Cycle Engineering \\
\hline & & EOL Treatment & Life Cycle Engineering \\
\hline & & Production Networks & $\begin{array}{l}\text { Production Systems and } \\
\text { Organizations }\end{array}$ \\
\hline OFHC & $\begin{array}{l}\text { Oxygen-Free High } \\
\text { Conductivity }\end{array}$ & Diamond Machining & Cutting \\
\hline OLTCM & $\begin{array}{l}\text { Online Tool Condition } \\
\text { Monitoring }\end{array}$ & Modeling of Face Milling & Cutting \\
\hline OMAC & $\begin{array}{l}\text { Open Modular Architecture } \\
\text { Controller }\end{array}$ & Open Architecture & Machines \\
\hline \multirow[t]{2}{*}{ OPD } & \multirow[t]{2}{*}{ Optical Path Difference } & Adaptive Optics & $\begin{array}{l}\text { Precision Engineering and } \\
\text { Metrology }\end{array}$ \\
\hline & & Interferometry & $\begin{array}{l}\text { Precision Engineering and } \\
\text { Metrology }\end{array}$ \\
\hline ORCOS & $\begin{array}{l}\text { Organic Reconfigurable } \\
\text { Operating System }\end{array}$ & Open Architecture & Machines \\
\hline ORESTE & $\begin{array}{l}\text { Organization, Rangement Et } \\
\text { Synthèse de Données } \\
\text { Relationnelles (fr) }\end{array}$ & Decision-Making & Design \\
\hline OSACA & $\begin{array}{l}\text { Open System Architecture for } \\
\text { Controls within Automation } \\
\text { Systems }\end{array}$ & Open Architecture & Machines \\
\hline
\end{tabular}




\begin{tabular}{|c|c|c|c|}
\hline Abbreviation & Explanation & Term & Section \\
\hline OSEC & $\begin{array}{l}\text { Open System Environment for } \\
\text { Controller }\end{array}$ & Open Architecture & Machines \\
\hline PBF & Powder Bed Fusion & $\begin{array}{l}\text { Additive Manufacturing } \\
\text { Technologies }\end{array}$ & $\begin{array}{l}\text { Electrophysical and Chemical } \\
\text { Processes }\end{array}$ \\
\hline PCA & $\begin{array}{l}\text { Principal Component } \\
\text { Analysis }\end{array}$ & Statistical Process Control & $\begin{array}{l}\text { Production Systems and } \\
\text { Organizations }\end{array}$ \\
\hline \multirow[t]{3}{*}{ PCB } & \multirow[t]{3}{*}{ Printed Circuit Boards } & SMD Component Placement & Assembly \\
\hline & & Electric Test & Assembly \\
\hline & & Wave Soldering & Assembly \\
\hline \multirow[t]{6}{*}{ PCBN } & \multirow[t]{6}{*}{ Polycrystalline Boron Nitride } & Electrochemical Dressing & Abrasive Processes \\
\hline & & Ceramic Cutting Tools & Cutting \\
\hline & & Hard Material Cutting & Cutting \\
\hline & & High-Speed Cutting & Cutting \\
\hline & & Self-Propelled Rotary Tool & Cutting \\
\hline & & Superhard Tools & Cutting \\
\hline \multirow[t]{7}{*}{ PCD } & \multirow[t]{7}{*}{ Polycrystalline Diamond } & Centerless Grinding & Abrasive Processes \\
\hline & & Electrochemical Dressing & Abrasive Processes \\
\hline & & Ceramic Cutting Tools & Cutting \\
\hline & & Composite Materials & Cutting \\
\hline & & $\begin{array}{l}\text { Machinability of Aluminum } \\
\text { and Magnesium Alloys }\end{array}$ & Cutting \\
\hline & & Self-Propelled Rotary Tool & Cutting \\
\hline & & Superhard Tools & Cutting \\
\hline PCM & Photochemical Machining & Etching & $\begin{array}{l}\text { Electrophysical and Chemical } \\
\text { Processes }\end{array}$ \\
\hline \multirow[t]{2}{*}{ PDM } & \multirow[t]{2}{*}{ Product Data Management } & Information Management & Design \\
\hline & & Production & $\begin{array}{l}\text { Production Systems and } \\
\text { Organizations }\end{array}$ \\
\hline PDMS & Polydimethylsiloxane & Microstructure & Surfaces \\
\hline \multirow[t]{2}{*}{ PECVD } & \multirow[t]{2}{*}{$\begin{array}{l}\text { Plasma-Enhanced Chemical } \\
\text { Vapor Deposition }\end{array}$} & $\begin{array}{l}\text { Chemical Vapor Deposition } \\
\text { (CVD) }\end{array}$ & $\begin{array}{l}\text { Electrophysical and Chemical } \\
\text { Processes }\end{array}$ \\
\hline & & Microwave Radiation & $\begin{array}{l}\text { Electrophysical and Chemical } \\
\text { Processes }\end{array}$ \\
\hline PEF & $\begin{array}{l}\text { Product Environmental } \\
\text { Footprints }\end{array}$ & Life Cycle Assessment & Life Cycle Engineering \\
\hline PHIGS & $\begin{array}{l}\text { Programmer's Hierarchical } \\
\text { Interactive Graphics System }\end{array}$ & $\begin{array}{l}\text { Computer-Aided } \\
\text { Manufacturing }\end{array}$ & $\begin{array}{l}\text { Production Systems and } \\
\text { Organizations }\end{array}$ \\
\hline \multirow[t]{2}{*}{ PID } & \multirow{2}{*}{$\begin{array}{l}\text { Proportional-Integral- } \\
\text { Derivative }\end{array}$} & Servo System & Machines \\
\hline & & Precision Positioning & $\begin{array}{l}\text { Precision Engineering and } \\
\text { Metrology }\end{array}$ \\
\hline \multirow[t]{2}{*}{ PLM } & \multirow[t]{2}{*}{$\begin{array}{l}\text { Product Lifecycle } \\
\text { Management }\end{array}$} & $\begin{array}{l}\text { Computer-Aided } \\
\text { Manufacturing }\end{array}$ & $\begin{array}{l}\text { Production Systems and } \\
\text { Organizations }\end{array}$ \\
\hline & & Production & $\begin{array}{l}\text { Production Systems and } \\
\text { Organizations }\end{array}$ \\
\hline \multirow[t]{2}{*}{$\mathrm{PPC}$} & \multirow[t]{2}{*}{$\begin{array}{l}\text { Production Planning and } \\
\text { Control }\end{array}$} & $\begin{array}{l}\text { Computer-Integrated } \\
\text { Manufacturing }\end{array}$ & $\begin{array}{l}\text { Production Systems and } \\
\text { Organizations }\end{array}$ \\
\hline & & $\begin{array}{l}\text { ERP Enterprise Resource } \\
\text { Planning }\end{array}$ & $\begin{array}{l}\text { Production Systems and } \\
\text { Organizations }\end{array}$ \\
\hline PRO & $\begin{array}{l}\text { Producer Responsibility } \\
\text { Organization }\end{array}$ & EOL Treatment & Life Cycle Engineering \\
\hline
\end{tabular}




\begin{tabular}{|c|c|c|c|}
\hline Abbreviation & Explanation & Term & Section \\
\hline PROMETHEE & $\begin{array}{l}\text { Preference Ranking } \\
\text { Organization Method for } \\
\text { Enrichment Evaluations }\end{array}$ & Decision-Making & Design \\
\hline PSB & Persistent Slip Band & Crack Initiation & Surfaces \\
\hline PSD & Position-Sensitive Detector & Sensor Assembly & Assembly \\
\hline PSO & Particle Swarm Optimization & $\begin{array}{l}\text { Twist Drill Geometry } \\
\text { Optimization }\end{array}$ & Cutting \\
\hline \multirow[t]{2}{*}{ PSS } & \multirow[t]{2}{*}{ Product-Service Systems } & EOL Treatment & Life Cycle Engineering \\
\hline & & $\begin{array}{l}\text { Industrial Product-Service } \\
\text { System }\end{array}$ & $\begin{array}{l}\text { Production Systems and } \\
\text { Organizations }\end{array}$ \\
\hline PTP & Peak-to-Peak & Chatter Prediction & Cutting \\
\hline $\mathrm{PV}$ & Process Variables & Axiomatic Design & Design \\
\hline \multirow[t]{8}{*}{ PVD } & \multirow[t]{8}{*}{ Physical Vapor Deposition } & Ceramic Cutting Tools & Cutting \\
\hline & & Coated Tools & Cutting \\
\hline & & Hard Material Cutting & Cutting \\
\hline & & $\begin{array}{l}\text { Chemical Vapor Deposition } \\
\text { (CVD) }\end{array}$ & $\begin{array}{l}\text { Electrophysical and Chemical } \\
\text { Processes }\end{array}$ \\
\hline & & Ion Beam Machining & $\begin{array}{l}\text { Electrophysical and Chemical } \\
\text { Processes }\end{array}$ \\
\hline & & $\begin{array}{l}\text { Physical Vapor Deposition } \\
\text { (PVD) }\end{array}$ & $\begin{array}{l}\text { Electrophysical and Chemical } \\
\text { Processes }\end{array}$ \\
\hline & & Sputtering & $\begin{array}{l}\text { Electrophysical and Chemical } \\
\text { Processes }\end{array}$ \\
\hline & & Peening & Surfaces \\
\hline PWB & Printed Wiring Boards & Disassembly & Life Cycle Engineering \\
\hline PWJ & Plain/Pure Waterjet & Waterjet Cutting & Abrasive Processes \\
\hline PWM & Pulse-Width Modulation & Magnetic Bearing & Machines \\
\hline QCPM & $\begin{array}{l}\text { Quick Chatter Prediction } \\
\text { Method }\end{array}$ & Chatter Prediction & Cutting \\
\hline \multirow[t]{3}{*}{ QFD } & \multirow[t]{3}{*}{ Quality Function Deployment } & Design Methodology & Design \\
\hline & & Function Modeling & Design \\
\hline & & Cooperative Engineering & $\begin{array}{l}\text { Production Systems and } \\
\text { Organizations }\end{array}$ \\
\hline QFN & Quad Flat No-Lead & Optical Inspection & Assembly \\
\hline RBM & Risk-Based Maintenance & Maintenance & Assembly \\
\hline $\mathrm{RCM}$ & $\begin{array}{l}\text { Reliability-Centered } \\
\text { Maintenance }\end{array}$ & Maintenance & Assembly \\
\hline RCSA & $\begin{array}{l}\text { Receptance Coupling } \\
\text { Substructure Analysis }\end{array}$ & Vibration & Machines \\
\hline RCWA & $\begin{array}{l}\text { Rigorous Coupled-Wave } \\
\text { Analysis }\end{array}$ & Scatterometry & Surfaces \\
\hline RDBMS & $\begin{array}{l}\text { Records and Database } \\
\text { Management Systems }\end{array}$ & Information Management & Design \\
\hline $\mathrm{RE}$ & Reverse Engineering & Reverse Engineering & Design \\
\hline $\mathrm{RE}$ & Requirements Engineering & Cooperative Engineering & $\begin{array}{l}\text { Production Systems and } \\
\text { Organizations }\end{array}$ \\
\hline REBO & $\begin{array}{l}\text { Reactive Empirical Bond } \\
\text { Order }\end{array}$ & Molecular Dynamics & Surfaces \\
\hline REX & Retour d'Experience (fr) & Knowledge Management & Design \\
\hline \multirow[t]{2}{*}{$\mathrm{RF}$} & \multirow[t]{2}{*}{ Radio Frequency } & Coated Tools & Cutting \\
\hline & & $\begin{array}{l}\text { Physical Vapor Deposition } \\
\text { (PVD) }\end{array}$ & $\begin{array}{l}\text { Electrophysical and Chemical } \\
\text { Processes }\end{array}$ \\
\hline
\end{tabular}




\begin{tabular}{|c|c|c|c|}
\hline Abbreviation & Explanation & Term & Section \\
\hline \multirow[t]{5}{*}{ RFID } & \multirow{5}{*}{$\begin{array}{l}\text { Radio-Frequency } \\
\text { Identification }\end{array}$} & Sensor Assembly & Assembly \\
\hline & & $\begin{array}{l}\text { Autonomous Production } \\
\text { Control }\end{array}$ & $\begin{array}{l}\text { Production Systems and } \\
\text { Organizations }\end{array}$ \\
\hline & & Factory & $\begin{array}{l}\text { Production Systems and } \\
\text { Organizations }\end{array}$ \\
\hline & & Logistics & $\begin{array}{l}\text { Production Systems and } \\
\text { Organizations }\end{array}$ \\
\hline & & Manufacturing System & $\begin{array}{l}\text { Production Systems and } \\
\text { Organizations }\end{array}$ \\
\hline RFW & Rotary Friction Welding & Welding & Assembly \\
\hline RGB & Red, Green, and Blue & Sensor Assembly & Assembly \\
\hline RIM & $\begin{array}{l}\text { Reconfigurable Inspection } \\
\text { Machines }\end{array}$ & $\begin{array}{l}\text { Reconfigurable } \\
\text { Manufacturing System }\end{array}$ & $\begin{array}{l}\text { Production Systems and } \\
\text { Organizations }\end{array}$ \\
\hline $\mathrm{RM}$ & Rapid Manufacturing & Rapid Tooling & $\begin{array}{l}\text { Electrophysical and Chemical } \\
\text { Processes }\end{array}$ \\
\hline \multirow[t]{5}{*}{ RMS } & \multirow[t]{5}{*}{$\begin{array}{l}\text { Reconfigurable } \\
\text { Manufacturing Systems }\end{array}$} & Capacity Planning & $\begin{array}{l}\text { Production Systems and } \\
\text { Organizations }\end{array}$ \\
\hline & & Manufacturing System & $\begin{array}{l}\text { Production Systems and } \\
\text { Organizations }\end{array}$ \\
\hline & & Mass Customization & $\begin{array}{l}\text { Production Systems and } \\
\text { Organizations }\end{array}$ \\
\hline & & Planning & $\begin{array}{l}\text { Production Systems and } \\
\text { Organizations }\end{array}$ \\
\hline & & $\begin{array}{l}\text { Reconfigurable } \\
\text { Manufacturing System }\end{array}$ & $\begin{array}{l}\text { Production Systems and } \\
\text { Organizations }\end{array}$ \\
\hline RoHS & $\begin{array}{l}\text { Restriction of Hazardous } \\
\text { Substances }\end{array}$ & EOL Treatment & Life Cycle Engineering \\
\hline \multirow[t]{2}{*}{ RPP } & \multirow[t]{2}{*}{$\begin{array}{l}\text { Reconfigurable Process } \\
\text { Planning }\end{array}$} & $\begin{array}{l}\text { Computer-Aided Process } \\
\text { Planning }\end{array}$ & $\begin{array}{l}\text { Production Systems and } \\
\text { Organizations }\end{array}$ \\
\hline & & Planning & $\begin{array}{l}\text { Production Systems and } \\
\text { Organizations }\end{array}$ \\
\hline RPT & Rise Per Tooth & Broaching & Cutting \\
\hline RT & Radiographic Testing & Crack Initiation & Surfaces \\
\hline RTP & Ready To Press & Cemented Carbides & Cutting \\
\hline RUM & Rotary Ultrasonic Machining & Machine Tool & Machines \\
\hline SBCE & $\begin{array}{l}\text { Set-Based Concurrent } \\
\text { Engineering }\end{array}$ & Lean Design & Design \\
\hline SBMF & Sheet-Bulk Metal Forming & Sheet-Bulk Metal Forming & Forming \\
\hline SCARA & $\begin{array}{l}\text { Selective Compliance } \\
\text { Assembly Robot Arm }\end{array}$ & Robot & Assembly \\
\hline $\mathrm{SCC}$ & $\begin{array}{l}\text { Structural Classification and } \\
\text { Coding }\end{array}$ & Complexity in Manufacturing & $\begin{array}{l}\text { Production Systems and } \\
\text { Organizations }\end{array}$ \\
\hline SCI & Spheroidal Cast Iron & $\begin{array}{l}\text { Machining of Spheroidal } \\
\text { Ductile Iron }\end{array}$ & Cutting \\
\hline \multirow[t]{4}{*}{$\mathrm{SCM}$} & \multirow[t]{4}{*}{ Supply Chain Management } & Cyber-Physical Systems & $\begin{array}{l}\text { Production Systems and } \\
\text { Organizations }\end{array}$ \\
\hline & & $\begin{array}{l}\text { ERP Enterprise Resource } \\
\text { Planning }\end{array}$ & $\begin{array}{l}\text { Production Systems and } \\
\text { Organizations }\end{array}$ \\
\hline & & Production & $\begin{array}{l}\text { Production Systems and } \\
\text { Organizations }\end{array}$ \\
\hline & & Supply Chain Management & $\begin{array}{l}\text { Production Systems and } \\
\text { Organizations }\end{array}$ \\
\hline
\end{tabular}




\begin{tabular}{|c|c|c|c|}
\hline Abbreviation & Explanation & Term & Section \\
\hline SCOR & $\begin{array}{l}\text { Supply Chain Operations } \\
\text { Reference }\end{array}$ & Supply Chain Management & $\begin{array}{l}\text { Production Systems and } \\
\text { Organizations }\end{array}$ \\
\hline SCP & Screen Printing & Solder Paste Printing & Assembly \\
\hline SDE & Specific Discharge Energy & Specific Energy & $\begin{array}{l}\text { Electrophysical and Chemical } \\
\text { Processes }\end{array}$ \\
\hline SDG & $\begin{array}{l}\text { Sustainable Development } \\
\text { Goals }\end{array}$ & Sustainability & Life Cycle Engineering \\
\hline SDJST & $\begin{array}{l}\text { Sequence-Dependent Job } \\
\text { Setup Times }\end{array}$ & Scheduling & $\begin{array}{l}\text { Production Systems and } \\
\text { Organizations }\end{array}$ \\
\hline SDM & Semi-Discretization Method & Chatter Prediction & Cutting \\
\hline \multirow[t]{3}{*}{ SDOF } & \multirow[t]{3}{*}{ Single Degree of Freedom } & Chatter Prediction & Cutting \\
\hline & & Damping & Machines \\
\hline & & Dynamics & Machines \\
\hline SDT & Small Displacement Torsor & $\begin{array}{l}\text { Tolerancing (Kinematic } \\
\text { Approach to) }\end{array}$ & Design \\
\hline SE & Specific Energy & Specific Energy & $\begin{array}{l}\text { Electrophysical and Chemical } \\
\text { Processes }\end{array}$ \\
\hline SEDD & $\begin{array}{l}\text { Sink Electro-Discharge } \\
\text { Dressing }\end{array}$ & Dressing & Abrasive Processes \\
\hline \multirow[t]{5}{*}{ SEM } & \multirow[t]{5}{*}{$\begin{array}{l}\text { Scanning Electron } \\
\text { Microscope }\end{array}$} & Positioning & $\begin{array}{l}\text { Precision Engineering and } \\
\text { Metrology }\end{array}$ \\
\hline & & $\begin{array}{l}\text { Scanning Electron } \\
\text { Microscope }\end{array}$ & $\begin{array}{l}\text { Precision Engineering and } \\
\text { Metrology }\end{array}$ \\
\hline & & Crack Initiation & Surfaces \\
\hline & & Nanotechnology & Surfaces \\
\hline & & Scatterometry & Surfaces \\
\hline SERS & $\begin{array}{l}\text { Surface-Enhanced Raman } \\
\text { Spectroscopy }\end{array}$ & Ion Beam Machining & $\begin{array}{l}\text { Electrophysical and Chemical } \\
\text { Processes }\end{array}$ \\
\hline SFF & Solid Freeform Fabrication & Cleaner Production & Life Cycle Engineering \\
\hline SFM & Scanning Force Microscopes & Atomic Force Microscopy & $\begin{array}{l}\text { Precision Engineering and } \\
\text { Metrology }\end{array}$ \\
\hline SFP & Single-Factor Productivity & Productivity & $\begin{array}{l}\text { Production Systems and } \\
\text { Organizations }\end{array}$ \\
\hline SHF & Sheet Hydroforming & $\begin{array}{l}\text { Hydroforming (Sheets and } \\
\text { Tubes) }\end{array}$ & Forming \\
\hline SK & Tool Shank & Tool Holder & Cutting \\
\hline \multirow[t]{3}{*}{ SL } & \multirow[t]{3}{*}{ Stereolithography } & Rapid Tooling & $\begin{array}{l}\text { Electrophysical and Chemical } \\
\text { Processes }\end{array}$ \\
\hline & & Specific Energy & $\begin{array}{l}\text { Electrophysical and Chemical } \\
\text { Processes }\end{array}$ \\
\hline & & $\begin{array}{l}\text { Additive Manufacturing } \\
\text { Technologies }\end{array}$ & $\begin{array}{l}\text { Electrophysical and Chemical } \\
\text { Processes }\end{array}$ \\
\hline SLCC & Societal Life Cycle Costing & Life Cycle Cost & Life Cycle Engineering \\
\hline SLID & Solid-Liquid Interdiffusion & Diffusion Soldering & Abrasive Processes \\
\hline \multirow[t]{2}{*}{ SLM } & \multirow[t]{2}{*}{ Selective Laser Melting } & Rapid Tooling & $\begin{array}{l}\text { Electrophysical and Chemical } \\
\text { Processes }\end{array}$ \\
\hline & & Cleaner Production & Life Cycle Engineering \\
\hline \multirow[t]{2}{*}{ SLS } & \multirow[t]{2}{*}{ Selective Laser Sintering } & $\begin{array}{l}\text { Additive Manufacturing } \\
\text { Technologies }\end{array}$ & $\begin{array}{l}\text { Electrophysical and Chemical } \\
\text { Processes }\end{array}$ \\
\hline & & Rapid Tooling & $\begin{array}{l}\text { Electrophysical and Chemical } \\
\text { Processes }\end{array}$ \\
\hline
\end{tabular}




\begin{tabular}{|c|c|c|c|}
\hline Abbreviation & Explanation & Term & Section \\
\hline & & Specific Energy & $\begin{array}{l}\text { Electrophysical and Chemical } \\
\text { Processes }\end{array}$ \\
\hline & & Cleaner Production & Life Cycle Engineering \\
\hline SM & Subtractive Manufacturing & Machine Tool & Machines \\
\hline \multirow[t]{2}{*}{ SMA } & \multirow[t]{2}{*}{ Shape Memory Alloys } & Actuator & Machines \\
\hline & & Corrosion & Surfaces \\
\hline SMC & Sliding Mode Controller & Control & Machines \\
\hline \multirow[t]{2}{*}{ SMD } & \multirow[t]{2}{*}{ Surface-Mount Device } & SMD Component Placement & Assembly \\
\hline & & Optical Inspection & Assembly \\
\hline SME & $\begin{array}{l}\text { Society of Manufacturing } \\
\text { Engineers }\end{array}$ & $\begin{array}{l}\text { Computer-Integrated } \\
\text { Manufacturing }\end{array}$ & $\begin{array}{l}\text { Production Systems and } \\
\text { Organizations }\end{array}$ \\
\hline SMED & $\begin{array}{l}\text { Single-Minute Exchange of } \\
\text { Die }\end{array}$ & Lean Production & $\begin{array}{l}\text { Production Systems and } \\
\text { Organizations }\end{array}$ \\
\hline SMS & Selective Mask Sintering & Rapid Tooling & $\begin{array}{l}\text { Electrophysical and Chemical } \\
\text { Processes }\end{array}$ \\
\hline \multirow[t]{2}{*}{ SMT } & \multirow[t]{2}{*}{ Surface-Mount Technology } & SMD Component Placement & Assembly \\
\hline & & Wave Soldering & Assembly \\
\hline SOI & Silicon On Insulator & Ion Beam Machining & $\begin{array}{l}\text { Electrophysical and Chemical } \\
\text { Processes }\end{array}$ \\
\hline SPC & Statistical Process Control & Statistical Process Control & $\begin{array}{l}\text { Production Systems and } \\
\text { Organizations }\end{array}$ \\
\hline SPI & Solder Paste Inspection & Optical Inspection & Assembly \\
\hline SPIF & $\begin{array}{l}\text { Single-Point Incremental } \\
\text { Forming }\end{array}$ & Incremental Forming & Forming \\
\hline SPM & Scanning Probe Microscopy & Nanotechnology & Surfaces \\
\hline \multirow[t]{2}{*}{ SPRT } & \multirow[t]{2}{*}{ Self-Propelled Rotary Tool } & Self-Propelled Rotary Tool & Cutting \\
\hline & & Turning with Rotary Tools & Cutting \\
\hline SQC & Statistical Quality Control & Statistical Process Control & $\begin{array}{l}\text { Production Systems and } \\
\text { Organizations }\end{array}$ \\
\hline SSS & Slow Slide Servo & Diamond Machining & Cutting \\
\hline STAGES & $\begin{array}{l}\text { Structured Analysis and } \\
\text { Generation of Expert Systems }\end{array}$ & Knowledge Management & Design \\
\hline STC & $\begin{array}{l}\text { Scientific Technical } \\
\text { Committee }\end{array}$ & Life Cycle Engineering & Life Cycle Engineering \\
\hline STEP & $\begin{array}{l}\text { Systems and Standards for } \\
\text { Exchange of Product Model } \\
\text { Data }\end{array}$ & $\begin{array}{l}\text { Geometrical Product } \\
\text { Specification }\end{array}$ & $\begin{array}{l}\text { Precision Engineering and } \\
\text { Metrology }\end{array}$ \\
\hline STFT & $\begin{array}{l}\text { Short-Time Fourier } \\
\text { Transformation }\end{array}$ & Monitoring & Cutting \\
\hline STL & Stereolithography & Freeform & Surfaces \\
\hline STL & Solid-to-Layer & Reverse Engineering & Design \\
\hline \multirow[t]{2}{*}{ STM } & \multirow[t]{2}{*}{$\begin{array}{l}\text { Scanning Tunneling } \\
\text { Microscope }\end{array}$} & $\begin{array}{l}\text { Scanning Tunneling } \\
\text { Microscope }\end{array}$ & $\begin{array}{l}\text { Precision Engineering and } \\
\text { Metrology }\end{array}$ \\
\hline & & Nanotechnology & Surfaces \\
\hline STP & Stencil Printing & Solder Paste Printing & Assembly \\
\hline SVDH & Self-Vibrating Drilling Head & Self-Vibratory Drilling & $\begin{array}{l}\text { Electrophysical and Chemical } \\
\text { Processes }\end{array}$ \\
\hline TACVD & $\begin{array}{l}\text { Thermally Activated } \\
\text { Chemical Vapor Deposition }\end{array}$ & $\begin{array}{l}\text { Chemical Vapor Deposition } \\
\text { (CVD) }\end{array}$ & $\begin{array}{l}\text { Electrophysical and Chemical } \\
\text { Processes }\end{array}$ \\
\hline $\mathrm{TC}$ & Thermocompression & Wire Bonding & Assembly \\
\hline TCA & Total Cost Assessment & Life Cycle Cost & Life Cycle Engineering \\
\hline
\end{tabular}




\begin{tabular}{|c|c|c|c|}
\hline Abbreviation & Explanation & Term & Section \\
\hline $\mathrm{TCF}$ & Tool Coordinate Frame & $\begin{array}{l}\text { Process Optimization via } \\
\text { Feedrate Scheduling in } \\
\text { Milling }\end{array}$ & Cutting \\
\hline TCM & Technical Cost Modeling & Cost & $\begin{array}{l}\text { Production Systems and } \\
\text { Organizations }\end{array}$ \\
\hline $\mathrm{TCO}$ & Total Cost of Ownership & Magnetic Bearing & Machines \\
\hline \multirow[t]{2}{*}{ TCP } & \multirow[t]{2}{*}{ Tool Center Point } & Chatter Prediction & Cutting \\
\hline & & Actuator & Machines \\
\hline \multirow[t]{2}{*}{ TEM } & \multirow{2}{*}{$\begin{array}{l}\text { Transmission Electron } \\
\text { Microscope }\end{array}$} & Deformation (Dislocations) & Forming \\
\hline & & $\begin{array}{l}\text { Scanning Electron } \\
\text { Microscope }\end{array}$ & $\begin{array}{l}\text { Precision Engineering and } \\
\text { Metrology }\end{array}$ \\
\hline \multirow[t]{2}{*}{ TEM } & \multirow{2}{*}{$\begin{array}{l}\text { Transmission Electron } \\
\text { Microscopy }\end{array}$} & Nanoindentation & Surfaces \\
\hline & & Nanotechnology & Surfaces \\
\hline THF & Tube Hydroforming & $\begin{array}{l}\text { Hydroforming (Sheets and } \\
\text { Tubes) }\end{array}$ & Forming \\
\hline THT & Through-Hole Technology & Wave Soldering & Assembly \\
\hline TI & Toughness Index & Abrasive Material & Abrasive Processes \\
\hline TIG & Tungsten Inert Gas & Welding & Assembly \\
\hline TIPS & $\begin{array}{l}\text { Theory of Inventive Problem } \\
\text { Solving }\end{array}$ & TRIZ & Design \\
\hline TIR & Thermal Infrared Testing & Crack Initiation & Surfaces \\
\hline TLPB & $\begin{array}{l}\text { Transient Liquid Phase } \\
\text { Bonding }\end{array}$ & Diffusion Soldering & Abrasive Processes \\
\hline TLPS & $\begin{array}{l}\text { Transient Liquid Phase } \\
\text { Sintering/ Soldering }\end{array}$ & Diffusion Soldering & Abrasive Processes \\
\hline TOC & Total Ownership Cost & Life Cycle Cost & Life Cycle Engineering \\
\hline TOPSIS & $\begin{array}{l}\text { Technique for Order of } \\
\text { Preference by Similarity to } \\
\text { Ideal Solution }\end{array}$ & Decision-Making & Design \\
\hline $\mathrm{TP}$ & Technological Process & Conceptual Design & Design \\
\hline TPIF & $\begin{array}{l}\text { Two-Point Incremental } \\
\text { Forming }\end{array}$ & Incremental Forming & Forming \\
\hline \multirow[t]{2}{*}{ TPM } & \multirow[t]{2}{*}{ Total Productive Maintenance } & Maintenance & Assembly \\
\hline & & Lean Production & $\begin{array}{l}\text { Production Systems and } \\
\text { Organizations }\end{array}$ \\
\hline TPS & Toyota Production System & Lean Production & $\begin{array}{l}\text { Production Systems and } \\
\text { Organizations }\end{array}$ \\
\hline TQC & Total Quality Control & Quality Assurance & $\begin{array}{l}\text { Precision Engineering and } \\
\text { Metrology }\end{array}$ \\
\hline \multirow[t]{2}{*}{ TQM } & \multirow[t]{2}{*}{ Total Quality Management } & Cooperative Engineering & $\begin{array}{l}\text { Production Systems and } \\
\text { Organizations }\end{array}$ \\
\hline & & Manufacturing System & $\begin{array}{l}\text { Production Systems and } \\
\text { Organizations }\end{array}$ \\
\hline TRIZ & $\begin{array}{l}\text { Teoria Reshenia } \\
\text { Izobretatelskih Zadatch (rus) }\end{array}$ & TRIZ & Design \\
\hline TS & Thermosonic & Wire Bonding & Assembly \\
\hline $\mathrm{TS}$ & Technical System & Conceptual Design & Design \\
\hline TSP & Traveling Salesman Problem & Logistics & $\begin{array}{l}\text { Production Systems and } \\
\text { Organizations }\end{array}$ \\
\hline TTI & Thermal Toughness Index & Abrasive Material & Abrasive Processes \\
\hline
\end{tabular}




\begin{tabular}{|c|c|c|c|}
\hline Abbreviation & Explanation & Term & Section \\
\hline TTRS & $\begin{array}{l}\text { Technologically and } \\
\text { Topologically Related } \\
\text { Surfaces }\end{array}$ & Tolerancing & Design \\
\hline UAM & $\begin{array}{l}\text { Ultrasonic Additive } \\
\text { Manufacturing }\end{array}$ & $\begin{array}{l}\text { Additive Manufacturing } \\
\text { Technologies }\end{array}$ & $\begin{array}{l}\text { Electrophysical and Chemical } \\
\text { Processes }\end{array}$ \\
\hline UDT & Universal Design Theory & Design Methodology & Design \\
\hline UHP & Ultrahigh-Pressure Pump & Waterjet Cutting & Abrasive Processes \\
\hline UNEP & $\begin{array}{l}\text { United Nations Environment } \\
\text { Programme }\end{array}$ & Cleaner Production & Life Cycle Engineering \\
\hline UP & Ultraprecision & Ultraprecision Grinding & Abrasive Processes \\
\hline US & Ultrasonic & Wire Bonding & Assembly \\
\hline USL & Upper Specification Limit & Statistical Process Control & $\begin{array}{l}\text { Production Systems and } \\
\text { Organizations }\end{array}$ \\
\hline USM & Ultrasonic Machining & Actuator & Machines \\
\hline USM Mills & Ultra-Small Micro-End Mills & Ultra-Small Micro-End Mills & Cutting \\
\hline UT & Ultrasonic Testing & Crack Initiation & Surfaces \\
\hline VAM & Vibration-Assisted Machining & Actuator & Machines \\
\hline VDI & Verein Deutscher Ingenieure & Creep-Feed Grinding & Abrasive Processes \\
\hline VDI & Virtual Device Metafile & $\begin{array}{l}\text { Computer-Aided } \\
\text { Manufacturing }\end{array}$ & $\begin{array}{l}\text { Production Systems and } \\
\text { Organizations }\end{array}$ \\
\hline VGA & Video Graphics Array & Product Architecture & Design \\
\hline VIM & $\begin{array}{l}\text { International Vocabulary of } \\
\text { Metrology }\end{array}$ & Traceability & $\begin{array}{l}\text { Precision Engineering and } \\
\text { Metrology }\end{array}$ \\
\hline VLT & $\begin{array}{l}\text { Very Large astronomical } \\
\text { Telescopes }\end{array}$ & Ultraprecision Grinding & Abrasive Processes \\
\hline VP & Virtual Prototyping & Prototyping & Design \\
\hline \multirow[t]{5}{*}{ VR } & \multirow[t]{5}{*}{ Virtual Reality } & Augmented Reality & Design \\
\hline & & Virtual Reality & Design \\
\hline & & Cooperative Engineering & $\begin{array}{l}\text { Production Systems and } \\
\text { Organizations }\end{array}$ \\
\hline & & Factory & $\begin{array}{l}\text { Production Systems and } \\
\text { Organizations }\end{array}$ \\
\hline & & Production & $\begin{array}{l}\text { Production Systems and } \\
\text { Organizations }\end{array}$ \\
\hline VSD & Value Stream Design & Lean Production & $\begin{array}{l}\text { Production Systems and } \\
\text { Organizations }\end{array}$ \\
\hline VSM & Value Stream Mapping & Lean Production & $\begin{array}{l}\text { Production Systems and } \\
\text { Organizations }\end{array}$ \\
\hline VT & Visual Testing & Crack Initiation & Surfaces \\
\hline WBCSD & $\begin{array}{l}\text { World Business Council for } \\
\text { Sustainable Development }\end{array}$ & Eco-efficiency & Life Cycle Engineering \\
\hline WCF & Workpiece Coordinate Frame & $\begin{array}{l}\text { Process Optimization via } \\
\text { Feedrate Scheduling in } \\
\text { Milling }\end{array}$ & Cutting \\
\hline WCS & Workpiece Coordinate System & $\begin{array}{l}\text { Five-Axis Tool Path } \\
\text { Generation }\end{array}$ & Cutting \\
\hline WEDD & $\begin{array}{l}\text { Wire Electro-Discharge } \\
\text { Dressing }\end{array}$ & Dressing & Abrasive Processes \\
\hline WEDM & $\begin{array}{l}\text { Wire Electro-Discharge } \\
\text { Machining }\end{array}$ & Etching & $\begin{array}{l}\text { Electrophysical and Chemical } \\
\text { Processes }\end{array}$ \\
\hline WEEE & $\begin{array}{l}\text { Waste Electrical and } \\
\text { Electronic Equipment }\end{array}$ & EOL Treatment & Life Cycle Engineering \\
\hline
\end{tabular}




\begin{tabular}{l|l|l|l}
\hline Abbreviation & Explanation & Term & Section \\
\hline WIP & Work In Process & Material flow & Assembly \\
\cline { 3 - 4 } & $\begin{array}{l}\text { Flexible Manufacturing } \\
\text { System }\end{array}$ & $\begin{array}{l}\text { Production Systems and } \\
\text { Organizations }\end{array}$ \\
\hline WLC & Whole-Life Costing & Life Cycle Cost & Life Cycle Engineering \\
\hline WMSD & $\begin{array}{l}\text { Work-Related } \\
\text { Musculoskeletal Disorders }\end{array}$ & Ergonomic Assessment & Assembly \\
\hline WT & Wavelet Transformation & Monitoring & Cutting \\
\hline XPS & $\begin{array}{l}\text { X-Ray Photoelectron } \\
\text { Spectroscopy }\end{array}$ & Surface Integrity & Cutting \\
\cline { 2 - 4 } & X-Ray Diffraction & Nanotechnology & Surfaces \\
\hline ZOA & Zeroth-Order Approximation & Chatter Prediction & Cutting \\
\hline & & & Cutting
\end{tabular}

